Der Medizinischen Fakultät der Georg-August-Universität eingereicht von Prof. Dr. med. F. T. Hufert

\title{
Etablierung und Evaluation eines vereinfachten, speziesunabhängigen
}

\section{Anti-RVFV-Nukleoprotein-ELISAs}

\author{
INAUGURAL-DISSERTATION \\ zur Erlangung des Doktorgrades \\ der Medizinischen Fakultät der \\ Georg-August-Universität zu Göttingen
}

vorgelegt von

Uurtsaikh Schmidt, geb. Balchin

aus

Bayantsagaan, Mongolei

Göttingen 2019 
Die vorliegende Dissertation wurde in Göttingen im Zeitraum von November 2011 bis März 2013 im Institut für Mikrobiologie und Virologie unter der Betreuung von Prof. Dr. med. F. T. Hufert angefertigt.

Dekan:

Referent:

Koreferent:

Datum der mündlichen Prüfung:
Prof. Dr. med. W. Brück

Prof. Dr. med. F. T. Hufert

Prof. Dr. rer. nat. S. Pöhlmann

8. Dezember 2021 
Hiermit erkläre ich, die Dissertation mit dem Titel „Etablierung und Evaluation eines vereinfachten, speziesunabhängigen Anti-RVFV-Nukleoprotein-ELISAs“ eigenständig angefertigt und keine anderen als die von mir angegebenen Quellen und Hilfsmittel verwendet zu haben.

Göttingen, den 30.06.2020

(Unterschrift) 


\section{Inhaltsverzeichnis}

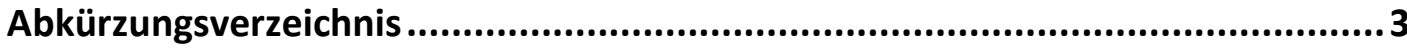

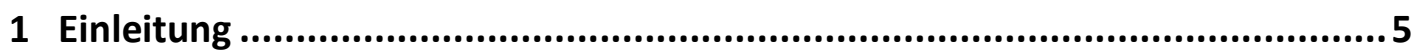

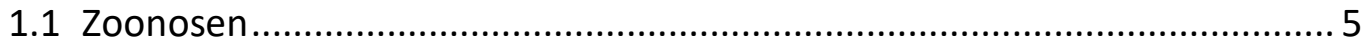

1.1.1 Ordnung Bunyavirales ............................................................... 7

1.1.2 Rift-Valley-Fever-Virus (RVFV)................................................... 9

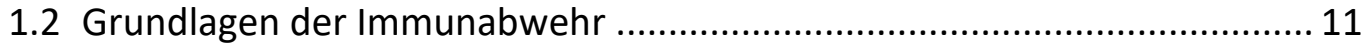

1.2.1 Spezifische (adaptive) Immunabwehr.......................................... 11

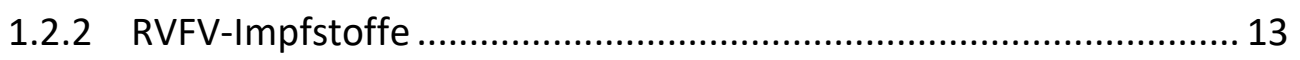

1.3 Labormethoden zum Nachweis von Virusinfektionen............................. 14

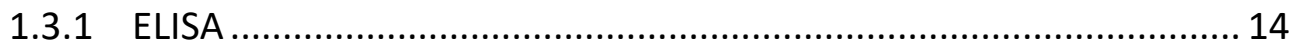

1.3.2 Bewertung von Nachweismethoden: Sensitivität und Spezifität .... 17

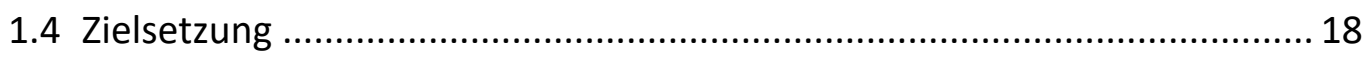

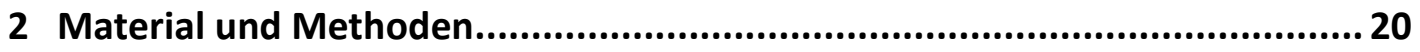

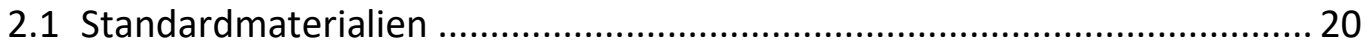

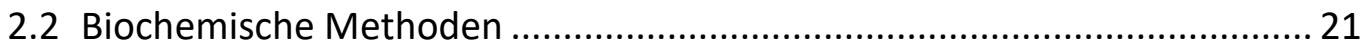

2.2.1 Protein-Expression in E. coli ....................................................... 21

2.2.2 Reinigung des Proteins über die Affinitätschromatographie mittels Ni-NTA-Agarose .............................................................. 23

2.2.3 Auftrennung der Proteine durch SDS-Polyacrylamid-

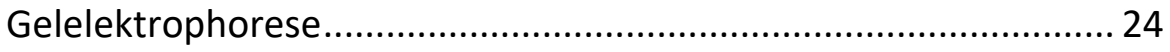

2.2.4 Transfer der Proteine auf die PVDF-Membran (Western Blot) ....... 26

2.2.5 Dialyse der eluierten RVFV-N-Proteinlösung .................................. 27

2.2.6 Färbung von Proteingelen ......................................................... 28

2.2.7 Bestimmung der Proteinkonzentration ........................................ 28

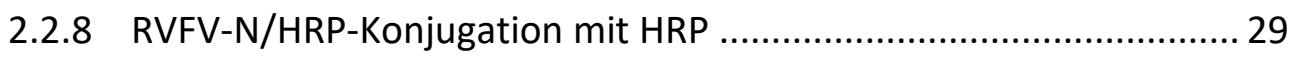

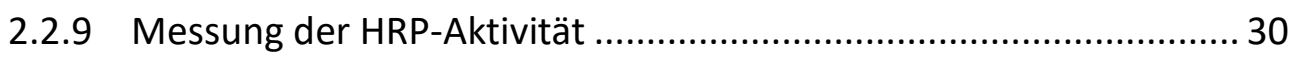

2.2.10 Speziesunabhängiger RVFV-N-ELISA ............................................. 31

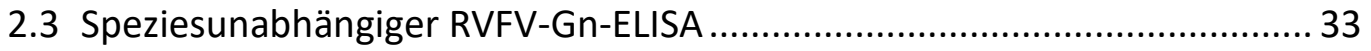

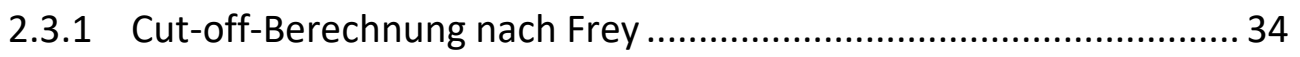

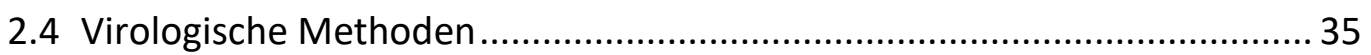

2.4.1 Anzucht von RVFV-KIon-13 in Zellkultur ...................................... 35

2.5 Molekularbiologische Methoden ............................................................... 36 


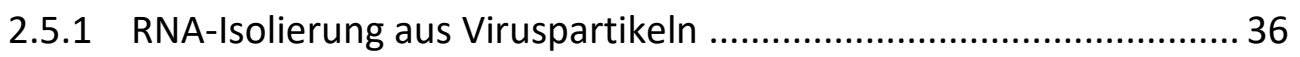

2.5.2 Spektrometrische Konzentrationsmessung von RNA …................ 37

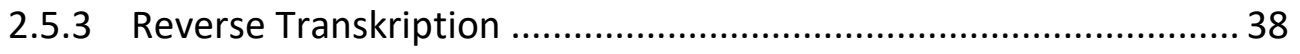

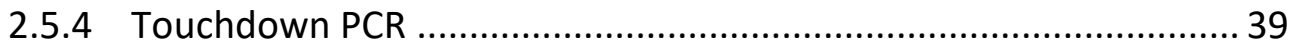

2.5.5 Agarosegelelektrophorese und -extraktion .................................... 41

2.5.6 TA-Klonierung: Ligation und Transformation.................................. 43

2.5.7 Isolation der Plasmid-DNA aus Bakterien ...................................... 46

2.5.8 Restriktionsverdau von Plasmid-DNA .......................................... 47

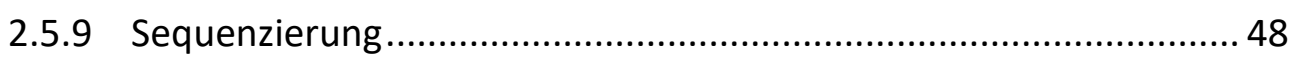

2.6 Immunfluoreszenztest als Referenzmethode ........................................... 48

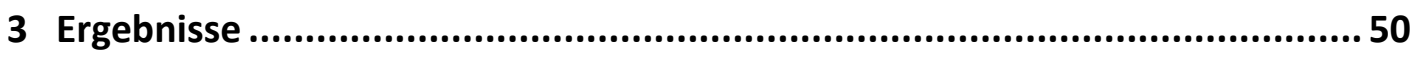

3.1 Etablierung des speziesunabhängigen, nichtkompetitiven ELISAs zur Detektion von RVFV-Nukleoprotein-Antikörpern................................... 50

3.1.1 Expression und Aufreinigung des RVFV-Nukleoproteins .................50

3.1.2 Konjugation des RVFV-Nukleoproteins mit HRP .............................51

3.1.3 Durchführung des ELISAs ............................................................ 53

3.2 Vergleich mit anderen Nachweismethoden .............................................. 53

3.2.1 Anpassung eines kommerziell verfügbaren RVFV-IFT als Referenzmethode................................................................... 54

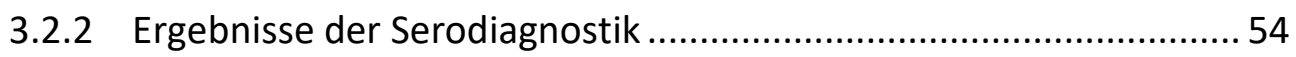

3.3 Entwicklung eines ELISAs zur Kontrolle des Impfschutzes.......................... 58

3.3.1 Herstellung des Plasmids pCRII-RVFV-Gn über TA-Klonierung ........ 59

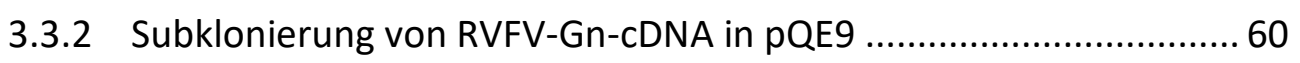

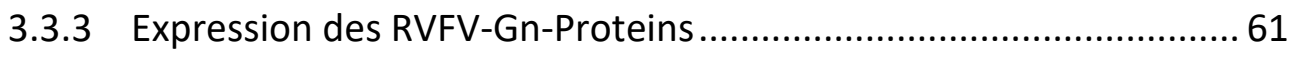

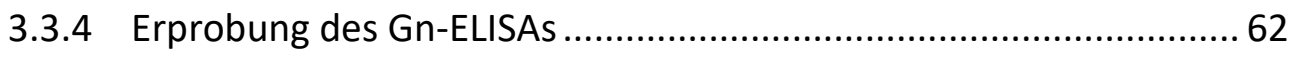

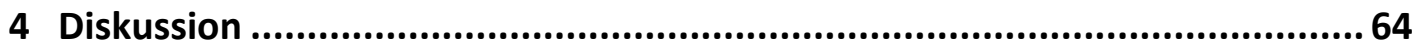

4.1 Erfolgreiche Etablierung eines speziesunabhängigen RVFV-N-ELISAs......... 64

4.2 Spezielle Aspekte der Verwendung eines ELISAs bei geimpften Tieren ....... 66

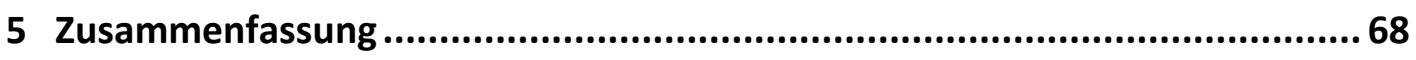

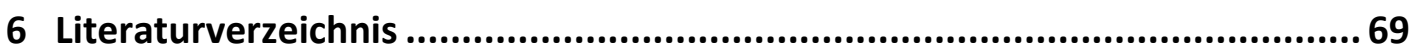




\section{Abkürzungsverzeichnis}

\begin{tabular}{|c|c|}
\hline AK & Antikörper \\
\hline AS & Aminosäure \\
\hline bp & Basenpaare \\
\hline BSA & bovines Serum-Albumin \\
\hline cDNA & komplementäre DNA \\
\hline CPE & zytopathischer Effekt \\
\hline $\mathrm{ddH}_{2} \mathrm{O}$ & ultrafiltriertes deionisiertes Wasser \\
\hline DEPC & Diethylpyrocarbonat \\
\hline DEPC- $\mathrm{H}_{2} \mathrm{O}$ & mit DEPC behandeltes und daher RNasefreies Wasser \\
\hline DMEM & Dulbecco's Modified Eagle's Medium \\
\hline DNA & Desoxyribonukleinsäure \\
\hline Dnase & Desoxyribonuklease \\
\hline dNTP & Desoxynukleotidtriphosphat \\
\hline Ds & Doppelstrang \\
\hline EDTA & Ethylendiamintetraacetat \\
\hline ELISA & Enzyme-linked Immunosorbent Assay \\
\hline FAO & Ernährungs- und Landwirtschaftsorganisation der Vereinten Nationen \\
\hline FKS & fetales Kälberserum \\
\hline g & Erdbeschleunigung \\
\hline IFN & Interferon \\
\hline IPTG & Isopropyl- $\alpha$-D-Thiogalactopyranosid \\
\hline kbp & Kilo-Basenpaare \\
\hline Lsg. & Lösung \\
\hline MEM & Minimum Essential Medium \\
\hline MOI & infektiöse Viruspartikel pro Zelle \\
\hline mRNA & Boten-RNA \\
\hline MW & Mittelwert \\
\hline
\end{tabular}


NICD National Institute for Communicable Diseases

NK natürliche Killerzellen

NS-Protein Nichtstruktur-Protein

ORF offener Leserahmen

PAGE Polyacrylamid-Gelelektrophorese

PBS Phosphat-gepufferte Salzlösung

PVDF Polyvinylidenfluorid

PCR Polymerase-Kettenreaktion

RKI Robert Koch Institut

RNA Ribonukleinsäure

RNase Ribonuklease

rpm Umdrehungen pro Minute

RT Raumtemperatur

RT reverse Transkriptase

RVFV Rift-Valley-Fever-Virus

SDS Natriumdodecylsulfat

ss Einzelstrang

TAE Tris-Acetat-EDTA-Puffer

Taq Thermus aquaticus

TCID $_{50} \quad$ Kulturinfektionsdosis $50 \%$

TEMED N,N, $\mathrm{N}^{\prime}, \mathrm{N}^{\prime}$-Tetramethylethylendiamin

Tris Tris-(hydroxymethyl)-aminomethan

VP virales Protein

wt Wildtyp 


\section{Einleitung}

\subsection{Zoonosen}

Der Begriff Zoonose erscheint erstmalig 1874 im Handbuch der allgemeinen Pathologie von Ernst Wagner (Wagner 1874). 1958 definierte die Weltgesundheitsorganisation (WHO) Zoonosen als Infektionskrankheiten, die bei Wirbeltieren natürlicherweise vorkommen und zwischen Tier und Mensch sowie umgekehrt übertragen werden (Krauss et al. 2004). Der Begriff leitet sich aus den griechischen Wörtern zoon (Lebewesen) und nosos (Krankheit) ab. Zu den Zoonosen gehören die ältesten bekannten Krankheiten wie Tuberkulose, zahlreiche lebensmittelbedingte Krankheiten wie Salmonellose, Krankheiten, die durch Vektoren übertragen werden wie Borreliose und Frühsommer-Meningoenzephalitis (FSME), durch resistente Keime wie den Methicillin-resistenten Staphylococcus aureus (MRSA) ausgelöste Erkrankungen, aber auch neue Krankheiten wie das Schwere Akute Respiratorische Syndrom (SARS). Durch schnelles Bevölkerungswachstum, zunehmende Mobilität, veränderte Tierzucht durch steigende Nachfrage nach tierischen Produkten sowie Klimaveränderungen gewinnen Zoonosen immer mehr an Bedeutung (Zoonosen.net 2019). Weltweit erkranken pro Jahr durch die 56 häufigsten Zoonosen 2,5 Milliarden Menschen, 2,7 Millionen sterben an den Folgen der Infektion. Am stärksten betroffen sind die Kontinente Afrika und Asien. Neu aufkommende Zoonosen sind vor allem in Westeuropa und dem Osten der USA registriert worden (ILRI 2012).

Bei einer 2001 durchgeführten Studie zeigte sich, dass es 1415 infektiöse Organismen und Partikel gibt, die beim Menschen Erkrankungen auslösen können: 217 Viren und Prionen, 538 Bakterien und Rickettsien, 307 Pilzarten, 66 Protozoen und 287 Helminthen. Es können bemerkenswerte 61 Prozent der Erkrankungen beim Menschen als zoonotischen Ursprungs charakterisiert werden (Taylor et al. 2001). Doch die Inzidenz und Prävalenz ist nicht genau erfassbar, da die Erkrankungen nicht alle meldepflichtig sind oder erst gar nicht diagnostiziert werden. Die Gefahr einer Infektion besteht bei häufigem und direktem Kontakt mit infizierten Tieren. Bestimmte Berufsgruppen wie Tierärzte und Landwirte sind, bedingt durch das häufige Zusammentreffen mit Vektoren, eher gefährdet als die 
Stadtbevölkerung. Immungeschwächte Menschen, wie alte Menschen, Kinder, Schwangere und Föten, sind auch leichter durch Infektionskrankheiten angreifbar. Das Infektionsrisiko kann durch das Vermeiden von Kontakt mit infizierten Nutz- und Haustieren und deren Produkten verringert werden. In einigen afrikanischen Ländern, wie Ägypten und Sudan, finden grenzüberschreitende Zuchttier- und Schlachtviehtransporte statt, die kaum oder gar nicht auf Tierseuchen überwacht werden. Der Zusammenarbeit von Human- und Veterinärmedizinern kommt bei der Eindämmung zoonotischer Erkrankungen ein besonderer Stellenwert zu, so beispielsweise bei der unerlässlichen Impfung von Nutztieren und Menschen.

Virale Zoonosen verursachen durch den Verlust der Nutztiere regional und national enorme ökonomische Kosten, u. a. durch eine verringerte Milch- und Fleischproduktion (Hartley et al. 2011). Dies trifft in besonderem Maße auf endemische Krankheiten wie zum Beispiel das Rift Valley Fever (RVF) zu, welches mit relevanten Krankheitsausbrüchen vornehmlich auf dem afrikanischen Kontinent und der arabischen Halbinsel vorkommt. Die Erkrankung wird durch Rift-Valley-Fever-Virus (RVFV), einem Mitglied der Familie Phenuiviridae aus der Ordnung Bunyavirales, verursacht (Abbildung 1). In afrikanischen Staaten südlich der Sahara wie zum Beispiel Tansania hat das RVF eine hohe Seroprävalenz von bis zu 29,3 Prozent. Die RVFV-IgG-Seroprävalenz in Tansania ist mit hohem Alter, geringem sozioökonomischem Status, Besitz von Rindern, naher Distanz zum Malawisee, erhöhter Vegetationsdichte und geringen Temperaturschwankungen assoziiert. Die RVFV-Antikörperpräsenz bei jungen Leuten weist auf eine aktuell stattfindende oder kürzlich erfolgte Viruszirkulation hin. (Heinrich et al. 2012). Durch die heutzutage vorherrschende Mobilität durch das Fliegen besteht ein potentiell weltweites Verbreitungsrisiko. So besteht beispielsweise ein Einführungspotential für das RVF in die USA, da im Süden der USA ähnliche klimatische Bedingungen herrschen wie in den afrikanischen Ursprungsländern. Lediglich die niedrigen Temperaturen im Winter stehen dort dem Heimischwerden der RVFV übertragenden Moskitoarten entgegen (ViralZone 2019). In Europa wurde das RVF bisher noch nicht beobachtet. In Deutschland gilt das RVF als anzeigepflichtige Tierseuche, des Weiteren sind RVF-Erkrankungen und Todesfälle beim Menschen nach dem Infektionsschutzgesetz IfSG meldepflichtig. Wegen der epidemiologischen Charakteristika, der klinischen Bedeutung 


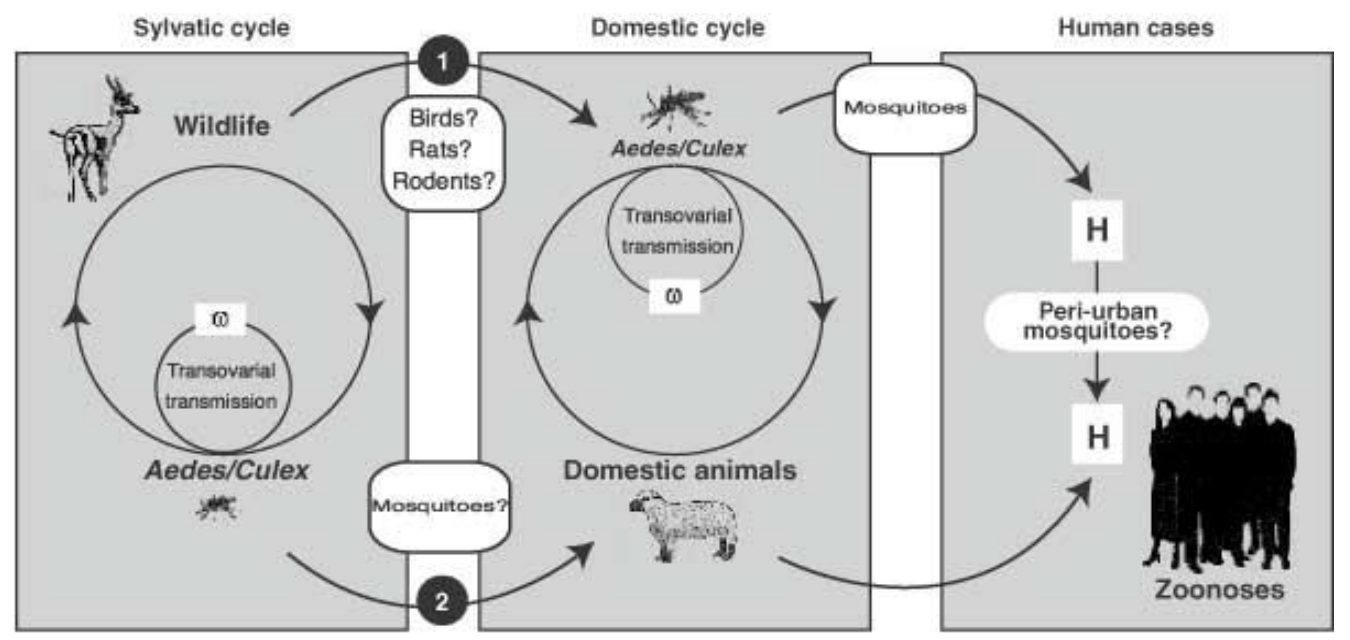

Abbildung 1: Theoretischer Zyklus der RVF-Virus Übertragung (Mondet 2003). Mit freundlicher Genehmigung der FAO.

und der Auswirkung auf die Landwirtschaft eines Landes wird das RVFV als potentielle biologische Waffe eingestuft (Kasari et al. 2008).

\subsubsection{Ordnung Bunyavirales}

Die Ordnung Bunyavirales umfasst zwölf Virusfamilien mit 287 taxonomisch gesicherten Virusarten. Die Ordnung umfasst Pflanzenviren, Viren, die nur Invertebraten infizieren, Viren, die sowohl Invertebraten (Arthropoden) als auch Säugetiere infizieren, sowie Viren, die nur Säugetiere (einschließlich des Menschen) infizieren. Der Begriff Bunyavirales leitet sich von dem Ort Bunyamwera in Uganda ab, wo das Bunyamweravirus, das innerhalb der Familie Perybunyaviridae zur Gattung Orthobunyavirus gezählt wird, erstmals isoliert wurde.

Die Virusarten der Familien Peribunyaviridae, Hantaviridae, Nairoviridae, Phenuiviridae und Tospoviridae besitzen prinzipiell denselben Aufbau: Es sind behüllte Viren, die als Genom eine einzelsträngige, dreifach segmentierte RNA mit negativer Polarität besitzen. Bunyaviren weisen eine sphärische Form mit einem Durchmesser von 100 bis $120 \mathrm{~nm}$ auf, die Spikes der Virushüllmembran bestehen aus einem Komplex zweier unterschiedlicher Glykoproteine Gn und Gc. Das Ribonukleokapsid ist von helikaler Symmetrie. Das Virusgenom setzt sich aus drei Segmenten bestehend aus einzelsträngigen RNAs mit negativer Polarität zusammen, die nach ihrer Größe mit large (L), middle (M) und small (S) 
bezeichnet werden (Abbildung 2). Das L-Segment kodiert das L-Protein, das eine RNA abhängige RNA-Polymerase darstellt. Das M-Segment enthält Informationen zu den für Infektion und Krankheitsentwicklung wichtigen Glykoproteinen Gn und Gc sowie dem Nichtstrukturprotein NSm. Das S-Segment kodiert das Nukleokapsidprotein N und das Nichtstrukturprotein NSs (Abbildung 3). Das NSs entsteht während der Virusreplikation und akkumuliert im Fall von RVFV im Kern infizierter Zellen. Es stellt einen wichtigen Virulenzfaktor dar, da das Protein die Interferonproduktion im RVFV-infizierten Organismus hemmt. Das Nukleoprotein N umhüllt die drei viralen Genomsegmente L, M und S.

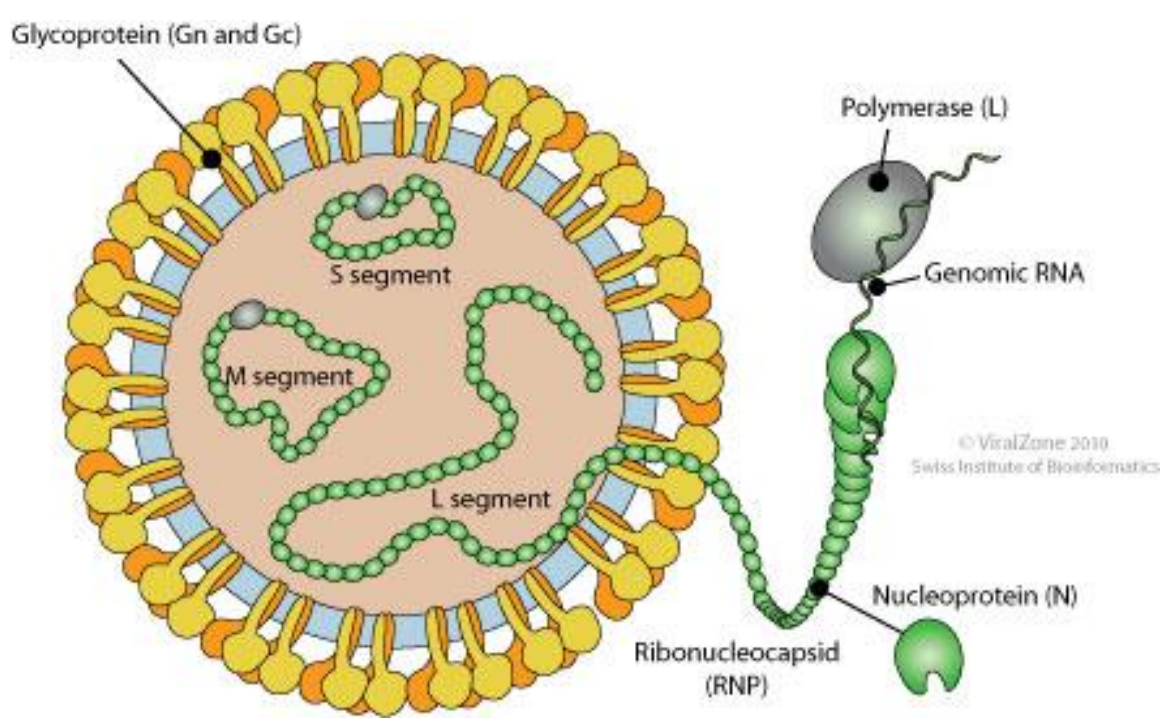

Abbildung 2: Virion (ViralZone 2019). Lizenziert unter CC BY-NC-ND 4.0.

Während das L- und M-Segment die für Bunyaviren typische negative Polarität aufweisen, besitzt das S-Segment eine Ambisense-Kodierung. Im Gegensatz zum Nukleoprotein-Gen, das negative Polarität besitzt, ist das Nichtstrukturprotein-Gen in positiver Polarität kodiert. Da die viralen Genom-Segmente kein 5'-Cap besitzen, kann der zelluläre Translationsapparat das NSs-Gen jedoch nicht direkt translatieren. Die auf dem L-Segment kodierte virale RNA-abhängige RNA-Polymerase (L-Protein) kann Genom-Segmente bzw. Gene mit negativer Polarität in mRNA umschreiben (Abbildung 3), die von der infizierten Zelle dann translatiert werden. Um das mit positiver Polarität kodierte NSs-Gen zu transkribieren, muss die virale Polymerase zunächst das komplette genomische S-Segment in ein antigenomisches S-Segment umschreiben. Auf diesem antigenomischen Segment 
liegt das NSs-Gen nun in negativer Polarität vor und kann somit von der viralen Polymerase transkribiert (Abbildung 3) und anschließend von der infizierten Zelle translatiert werden (Flint et al. 2004). Desweiteren dienen die antigenomischen Gen-Segmente auch als Vorlage zur Herstellung neuer genomischer Genom-Segmente durch die virale Polymerase im Verlauf der Virusreplikation. Daher werden von der viralen Polymerase nicht nur das SSegment, sondern auch die $\mathrm{M}$ - und L-Segmente in die jeweiligen antigenomischen Segmente umgeschrieben.

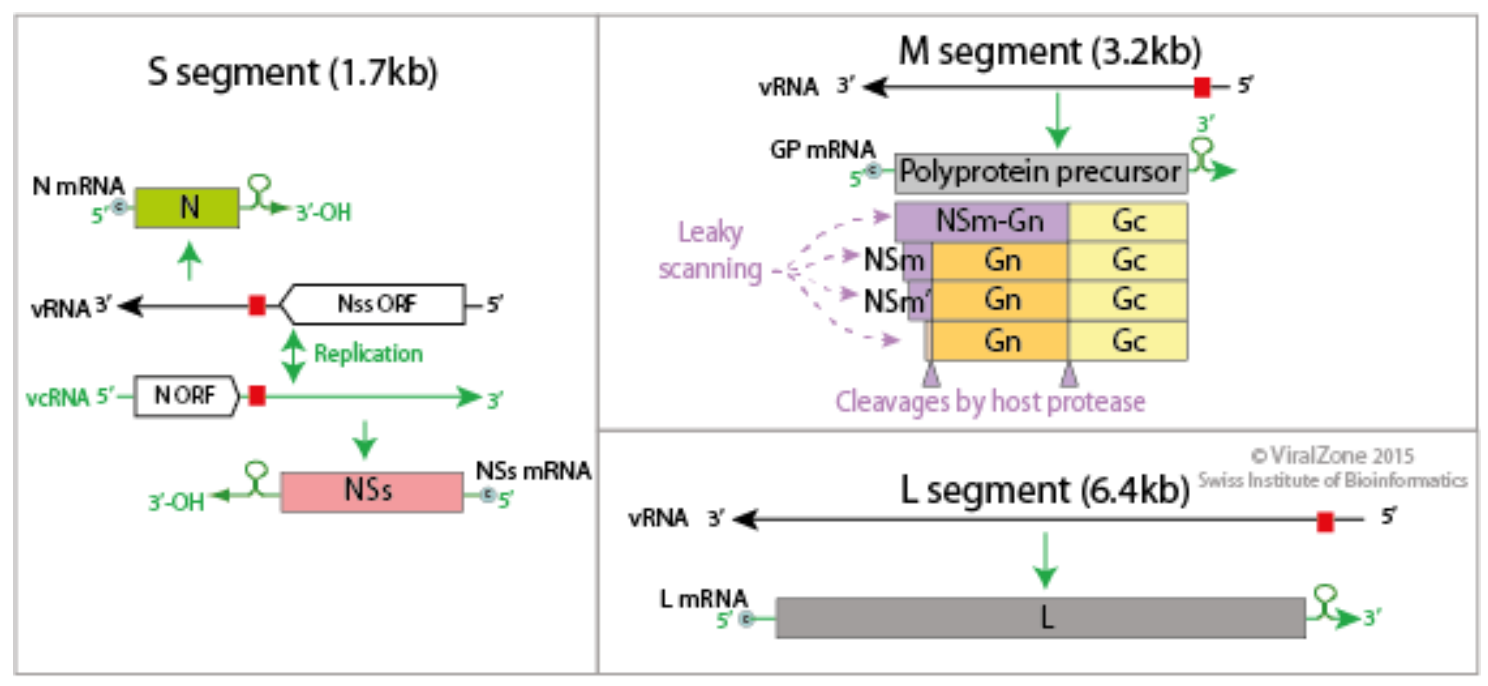

Abbildung 3: Das Genom des Rift-Valley-Fieber-Virus, ein Vertreter der Phenuiviren (ViralZone 2019). Lizenziert unter CC BY-NC-ND 4.0.

Bunyaviren der Familien Peribunyaviridae, Nairoviridae und Phenuiviridae vermehren sich in Vertebraten und Arthropoden. Da die Replikation in Arthropoden- im Gegensatz zu Vertebratenzellen kaum zytolytisch verläuft, verbreiten Arthropoden das Virus als Vektor (Modrow et al. 2010).

\subsubsection{Rift-Valley-Fever-Virus (RVFV)}

Das RVFV konnte erstmalig 1931 in dem gleichnamigen Tal (Rift Valley) in Kenia aus moribunden Schafen isoliert werden (Daubney et al. 1931). Bereits 1930 kam es im Osten Afrikas zur ersten großen Epidemie. Seither ist das Virus endemisch und epidemisch in ganz Afrika, zum Beispiel in Ägypten, Madagaskar und den Komoren (Heinrich et al. 2012). 1978 erkrankten in Ägypten 200.000 Menschen an Rift-Valley-Fever-Viren, wovon 600 starben, im Jahr 2000 erkrankten mehr als 20.000 in Saudi-Arabien und Jemen, mit einer ähnlich 
hohen Mortalitätsrate (Madani et al. 2003). Der Ausbruch in Saudi-Arabien und Jemen und damit auf der arabischen Halbinsel war der erste außerhalb des afrikanischen Kontinents. In neuerer Zeit wurden Epidemien z. B. 2008 in Madagaskar und 2010 in Südafrika gemeldet (Corso et al. 2008; NICD 2018). Das RVFV befällt hauptsächlich Wiederkäuer wie Schafe, Ziegen, Rinder, Kamele und Antilopen, dazu auch Pferde, Esel und verschiedene Vogelarten. Während einer Epidemie treten Erkrankungen auch beim Menschen auf (Abbildung 1), eine Mensch-zu-Mensch Übertragung ist bisher jedoch nicht beobachtet wurden. Das Virus kann durch Aerosole, durch direkten Kontakt mit infizierten Tieren bei der Schlachtung oder durch verschiedene Stechmückenarten, wie Aedes und Culex, auf den Menschen übertragen werden. Klinisch dominieren bei Wiederkäuern gastrointestinale Symptome mit Fieber mit bis zu 70\% Letalität. Bei trächtigen Tieren kommt es zu Fehl- bzw. Totgeburten mit einer Rate von bis zu 100\%, den sogenannten „abortion storms“. Erkrankungen beim Menschen sind oft subklinisch oder ähneln nach einer Inkubationszeit von zwei bis sechs Tagen einer Grippe mit hohem Fieber, Kopf- und Muskelschmerzen, retroorbitalen Schmerzen und Photophobie. Tödliche Verläufe mit Raten bis zu 15\% werden regelmäßig nach Hämorrhagien, Meningitis, Enzephalitis und Retinitis beobachtet. Vor allem bei AedesMücken bleibt das Virus durch transovarielle Übertragung als Reservoir erhalten. Durch den Stich der Mücke gelangt das Virus in die Blutbahn des Wirts und infiziert Monozyten, Makrophagen und andere Zellen. Die Virämie erreicht schließlich Zielorgane wie die Leber, das Zentralnervensystem und bei trächtigen Tieren den Fetus. Das Bild der infektiösen Hepatitis und Lebernekrose und damit das klinische Bild des Ikterus treten bei der Erkrankung von Tieren nicht auf, beim Menschen jedoch besonders oft. Eine antivirale Therapie mit Ribavirin kombiniert mit Interferon wurde bisher nicht bei Menschen angewendet, daher ist die Expositionsprophylaxe gegen Insektenstiche sehr anzuraten. In Experimenten mit RVFV infizierten Mäusen und Affen erwies sich die kausale Therapie als effizient (Peters et al. 1986). Tiere und Menschen, die bereits an RVF erkrankt waren, weisen eine andauernde und schützende Immunität auf (Modrow et al. 2010). 


\subsection{Grundlagen der Immunabwehr}

Bei den Wirbeltieren stellt das Immunsystem einen wesentlichen Bestandteil der Abwehr von Krankheitserregern wie Viren, Bakterien, Pilzen, Parasiten und deren Toxinen dar (Raem et al. 2007; Warrington et al. 2011). Es besteht aus einer Vielzahl an verschiedenen Zellen und Molekülen und ist in der Lage, zwischen körperfremden und körpereigenen Strukturen zu unterscheiden. Körperfremde Strukturen, die in den Organismus eindringen und eine Immunantwort hervorrufen können, werden als Antigene bezeichnet. Es gibt zwei Abwehrmechanismen, den erregerunspezifischen, angeborenen, und den erregerspezifischen, adaptativen. Beide Mechanismen greifen ineinander. Das angeborene Immunsystem schützt beim ersten Kontakt mit den Krankheitserregern. Dazu gehören physiologische Barrieren, wie Schleimhäute und lytische Enzyme in den Körperflüssigkeiten. Gelangen Mikroorganismen trotz dieser Barrieren in den Körper, werden sie durch Zellen des angeborenen Abwehrsystems angegriffen. Phagozyten wie Makrophagen, Monozyten und neutrophile Granulozyten erkennen Antigene anhand typischer Strukturmerkmale ihrer Oberflächen und zerlegen sie schließlich intrazellulär in Einzelmoleküle. Auf diese Weise werden Krankheitserreger unschädlich gemacht oder zumindest ihre Vermehrung und Ausbreitung im Organismus gebremst. Durch Signalstoffe, die diese Immunzellen sezernieren, können Entzündungen und Fieber auftreten, gleichzeitig werden noch ruhende Immunzellen mobilisiert. Makrophagen präsentieren auf ihren MHC-Rezeptoren Bruchstücke der zerlegten Antigene und leiten so eine Reaktion der Immunzellen der spezifischen Abwehr ein. Parallel dazu werden Antigen-markierte Antikörper von der unspezifischen Abwehr aus dem Organismus entfernt.

\subsubsection{Spezifische (adaptive) Immunabwehr}

Bei der adaptativen Abwehr reagiert das Immunsystem mit Anpassung, $d$. h. es werden auf einen individuellen Krankheitserreger abgestimmte Abwehrmaßnahmen eingeleitet. Insbesondere werden Oberflächenmerkmale von Antigenen von Antigen-präsentierenden Zellen (APCs) identifiziert, die diese Information dann an Abwehrzellen weiterreichen, um einen gezielten Angriff einzuleiten. Dies geschieht mittels T- und B-Lymphozyten. Nach Heranreifung der T-Lymphozyten im Thymus gewährleisten diese die zellvermittelte 


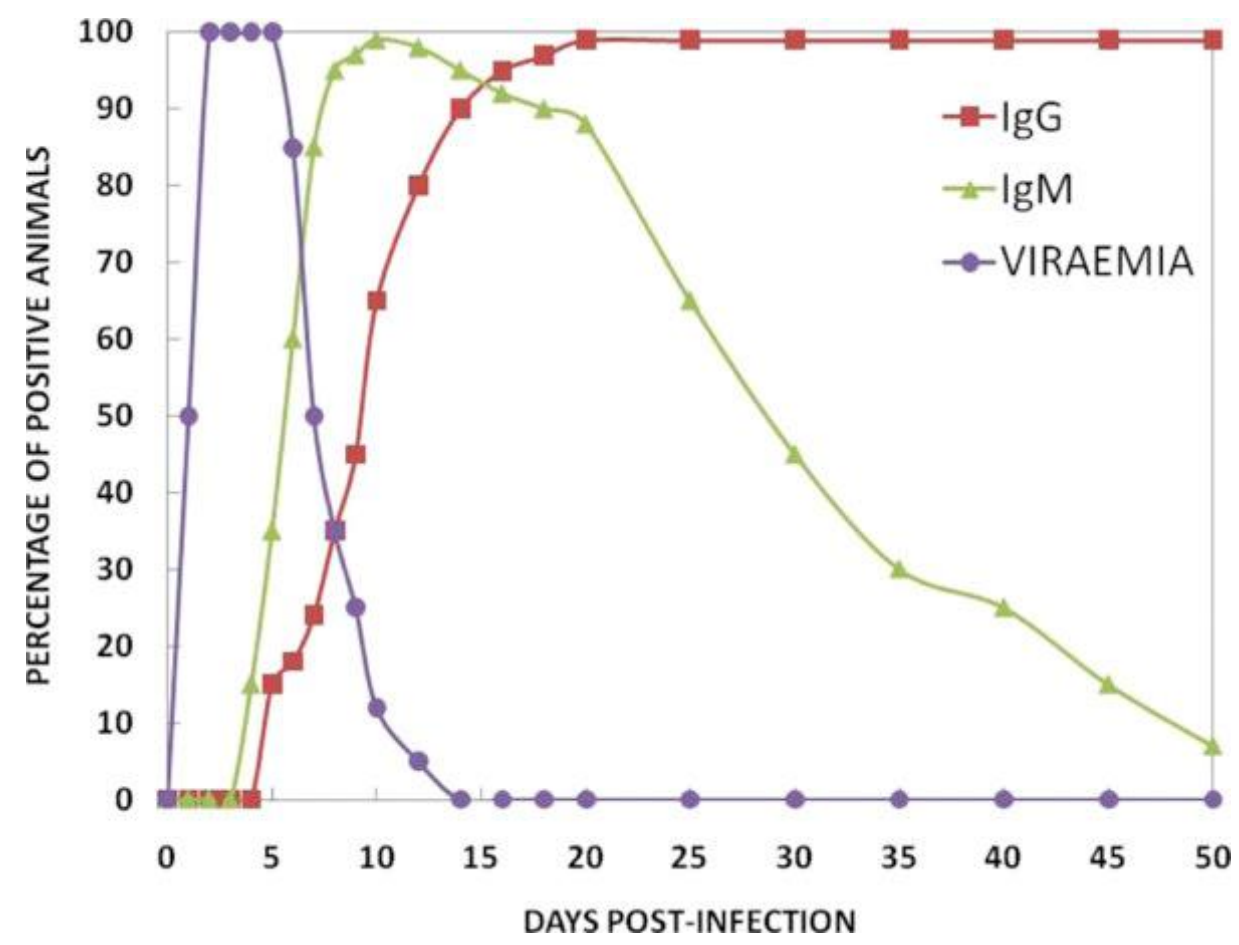

Abbildung 4: Verlauf der Virämie und Antikörperantwort bei RVFV (Pepin et al. 2010). Lizenziert unter CC BY-NC 3.0.

Immunantwort, indem sich einige T-Zellen zu zytotoxischen T-Zellen umwandeln und infizierte Zellen direkt angreifen. B-Lymphozyten dagegen befinden sich nach ihrer Bildung hauptsächlich in Lymphknoten und Milz und wandeln sich als Teil der antikörpervermittelten, humoralen Immunantwort zu Plasmazellen um. Diese produzieren spezielle lösliche Antikörper, die in der Lage sind, bestimmte Antigene extrazellulär nach dem Schlüssel- und Schloss-Prinzip zu erkennen und an sie zu binden und verhindern so ihre Verbreitung im Körper (Neutralisierung). Diese Antikörper können so z. B. das Anheften von Viren an körpereigene Zellen verhindern, indem sie an Proteine auf der Virusmembran binden und diese so blockieren. Bei der Opsonisierung markieren Antikörper Antigene, wodurch Makrophagen zum Phagozytieren angeregt werden. Antikörper der Klasse IgG und IgM sind zudem auch in der Lage, das Komplementsystem, das einen Teil der angeborenen Immunität darstellt, zu aktivieren. Durch den Antigen-Antikörper-Komplex wird der C1Protein-Komplex in der Kaskade des Komplementsystems aktiviert, was letztlich zur Lyse des Erregers führt. Durch die Bildung von Gedächtniszellen aus B-Lymphozyten reagiert das Immunsystem schneller und wirksamer auf bekannte Antigene. 
Die durch die adaptive Immunabwehr produzierten Antikörper sind frühestens vier bis acht Tage nach der Infektion mit RVFV messbar. Sie sind hauptsächlich gegen das virale Nukleoprotein N sowie die viralen Glykoproteine $\mathrm{Gn}$ und Gc gerichtet, in geringerem Ausmaß werden auch Antikörper gegen das Nichtstrukturprotein NSs gebildet. Da das NSsProtein nicht Bestandteil des Viruspartikels ist, kann der gleichzeitige Nachweis von NSs-, $\mathrm{N}$ - und $\mathrm{Gn} / \mathrm{Gc}$-Antikörpern für die Unterscheidung von infizierten und geimpften Individuen (nur Nachweis von N und/oder Gn/Gc-Antikörpern) herangezogen werden (DIVA-Methode, differentiation of infected and vaccinated animals, Bird et al. 2009). Bei Verwendung von Lebendimpfstoffen funktioniert diese Unterscheidung aber nur bei Verwendung von attenuierten Viren, die kein NSs exprimieren, nicht aber beim Einsatz von älteren Varianten wie dem Smithburn-Stamm (1.2.2), dem ersten Lebendimpfstoff, der bei Nutztieren eingesetzt wurde. Wie bei den meisten Infektionserkrankungen sind die ersten nachweisbaren Antikörper im Verlauf einer RVFV-Infektion IgM-Antikörper. Sie sind bereits in der virämischen Phase gut nachweisbar, verschwinden aber ca. zwei Monate nach der Infektion wieder. Etwa zwei Wochen nach der Infektion werden IgG-Antikörper nachweisbar, die nach dem Abklingen der akuten Erkrankung persistieren und vor Reinfektion schützen (Abbildung 4, Pepin et al. 2010).

\subsubsection{RVFV-Impfstoffe}

Momentan sind zugelassene RVFV-Impfstoffe für den Menschen nicht verfügbar. Für Tiere sind Impfstoffe erhältlich, die aufgrund der sozioökonomischen Auswirkung des RVFV in den afrikanischen Ländern dringend gebraucht werden. Bei Mäusen versprach die Impfung mittels eines attenuierten Lebendimpfstoffs (Smithburn-Stamm), welcher schon über sechzig Jahre verwendet wird, Immunität für drei Jahre. Bei trächtigen Schafen, Kühen und Ziegen kam es jedoch durch die Utero-Transmission des geimpften Virusstammes in vielen Fällen zu Fehlgeburten und Teratogenität, da er seine Virulenz nicht vollständig verloren hat. Aus diesem Grund wird dieser hoch immunogene Impfstoff nur während eines Ausbruchs und bei nicht-trächtigen Tieren angewendet. Seitdem entwickelte Totimpfstoffe sind zwar sicherer aber weniger effektiv, und müssen zudem mehrfach appliziert werden (Ahmed Kamal 2011). 


\subsection{Labormethoden zum Nachweis von Virusinfektionen}

RVF gehört zu den viralen hämorrhagischen Fiebererkrankungen wie Ebola, Marburg und Lassa, verläuft aber bei ausgewachsenen Tieren und Menschen oft subklinisch (Pepin et al. 2010). Im Falle eines klinischen Verlaufs besteht jedoch die Gefahr einer Organmanifestation und Hämorrhagie. Einer schnellen und zuverlässigen Diagnostik kommt eine Schlüsselfunktion bei der Früherkennung erkrankter Individuen zu, um diese rechtzeitig zu isolieren und so die Verbreitung des Virus einzudämmen. Weiterhin kann die Wahrscheinlichkeit von Folgeschäden, wie z. B. Erblindung, bei früh einsetzender Behandlung reduziert werden, auch wenn diese aufgrund fehlender zugelassener Medikamente gegen RVF derzeit nur auf die Linderung der Symptome abzielen kann.

Die Diagnose einer RVFV Infektion erfolgt direkt durch Virusproteinnachweis in infiziertem Gewebe oder durch Amplifizierung des Virusgenoms mittels PCR. Die quantitative RT-PCR ermöglicht während der akuten Phase der Infektion eine schnelle Identifikation des Virus. Diese Untersuchungen können nur in der virämischen Phase in den ersten zwei bis sieben Krankheitstagen erfolgen, was schwer zu bewerkstelligen und mit einem Infektionsrisiko verbunden ist. Da die Virämie bei infizierten Personen nicht lange besteht, sind gleichzeitige IgM- und IgG-Antikörpersuchtests für den indirekten Virusnachweis sinnvoll. Ab dem vierten Krankheitstag nach der Inkubationszeit ist es möglich, spezifische Antikörper gegen RVFV zu bestimmen (RKI 2007). Weitere serologische Möglichkeiten des RVFVInfektionsnachweises sind Hämagglutinations- und Komplement-Fixations-Tests, Westernblots sowie ELISAs. Eine sichere Unterscheidung zwischen aktueller und abgelaufener Infektion lässt sich in der Serologie nur mit antikörperklassenspezifischen ELISAs als indirekter Nachweismethode erzielen (Pepin et al. 2010).

\subsubsection{ELISA}

Das Akronym ELISA, für Enzyme-Linked Immunosorbent Assay, bezeichnet einen enzymgekoppelten Immunadsorptionstest, bei dem ein positiver Nachweis eines Analyten durch eine enzymatische Reaktion zur Umsetzung eines Farbstoffsubstrates erfolgt. 
Vorläufer des ELISAs war der 1960 von Rosalyn Sussman Yalow und Solomon Berson entwickelte Radioimmunoassay (Yalow und Berson 1960). Die Radioaktivität dient dabei als Signal, ob in der Probe das gesuchte Antigen oder der gesuchte Antikörper vorliegt. Die Kopplung von Proteinen (Antikörper mit Enzym) wurde von Stratis Avrameas und G. B. Pierce etabliert. 1966 zeigten Wide und Jerker Porath die Möglichkeit der Immunglobulinadsorption an Kunststoffoberflächen. Mit diesen Voraussetzungen gelang 1971 Peter Perlmann und Eva Engvall aus der Stockholmer Universität in Schweden, sowie Anton Schuurs und Bauke van Weemen in den Niederlanden unabhängig voneinander die Entwicklung des Festphasen-Enzymimmunoassays EIA/ELISA (Key 2007).

Mit verschiedenen ELISA-Methoden können Viren bzw. Virusbestandteile und Antikörper (beides Proteine), Hormone, Toxine und Pestizide in Proben nachgewiesen werden. Im Folgenden wird zunächst auf den Nachweis von Antikörpern im Blutserum eingegangen, dem häufigsten Einsatzzweck des ELISAs. Das Nachweisverfahren beruht auf einer hochspezifischen Antigen-Antikörperbindung. Es existieren verschiedene ELISA-Methoden zum Antikörpernachweis. Im indirekten Assay bindet der nachzuweisende Antikörper an ein spezifisches Antigen, das zuvor (unspezifisch) auf einen festen Träger aufgebracht wurde. Dieser Komplex wird durch einen markierten Sekundärantikörper detektiert, der gegen den Fc-Teil des nachzuweisenden Antikörpers gerichtet ist. Vorteile dieses Tests sind die geringere Zahl an Inkubationsschritten, wodurch unspezifische Bindungen verringert werden, und die Signalverstärkung, da an jeden nachzuweisenden Antikörper mehrere Sekundärantikörper binden können.

Die Markierung des Detektionsantikörpers kann aus radioaktiven Isotopen, fluorogenen oder luminogenen Molekülen oder Enzymen bestehen. Bei der Umsetzung des Substrats durch ein Enzym, meistens Meerrettichperoxidase (englisch: horseradish peroxidase, HRP), welches ein sehr weit verbreitetes und ausgereiftes Verfahren darstellt, erfolgt eine Farbentwicklung und somit der Antikörpernachweis. Mit Hilfe eines Photometers ist es darüber hinaus möglich, die Antikörperkonzentration zu bestimmen. Vor allem in der klinischen Diagnostik lassen sich auf diese Weise viele Proben unter gleichen Bedingungen in kurzer Zeit mit wenigen Verbrauchsartikeln automatisch messen. 
Bei einem kompetitiven ELISA fehlt der Detektionsantikörper. An seine Stelle tritt ein enzymmarkierter Kompetitionsantikörper, welcher mit dem Analyten (dem nachzuweisenden Antikörper) um denselben Bindungsplatz an dem immobilisierten Antigen konkurriert. Der Kompetitionsantikörper wird der Probe und einem Satz von Standards mit definierten Mengen des nachzuweisenden Antikörpers zugegeben, so dass die Konzentration des Analyten über eine Referenzkurve bestimmt werden kann. Das Signal ist dabei gegenläufig zur Analyt-Konzentration, d. h. die Farbreaktion verläuft umso stärker, je geringer der Analyt in der Probe konzentriert ist. Mit Hilfe eines solchen Assays lassen sich insbesondere Antikörper quantifizieren, die gegen niedermolekulare Analyten gerichtet sind, welche für eine gleichzeitige Bindung von zwei Antikörpern zu klein sind. Weiterhin ist der Antikörpernachweis mittels eines kompetitiven ELISAs speziesunabhängig, da für die gemessene Bindungskompetition nur die Spezifität, nicht aber die Spezies aus der der nachzuweisende Antikörper stammt, entscheidend ist. Nachteil dieses Verfahrens ist eine vergleichsweise hohe Mindestmenge an zu untersuchendem Analyten.

Bei einem Sandwich ELISA werden nicht Antikörper, sondern immunogene Substanzen im Serum (Antigene) nachgewiesen, insbesondere die infektiösen Erreger selbst bzw. deren Bestandteile wie z. B. Oberflächenproteine. Die Mikrotiterplatte wird hierzu mit einem spezifischen Antikörper beschichtet, an den das nachzuweisende Antigen bindet. Anschließend wird ein Detektionsantikörper zugegeben, welcher ebenfalls an das nun immobilisierte Antigen bindet. Das nachzuweisende Antigen muss über mindestens zwei unterschiedliche Epitope verfügen, damit zwei spezifische Antikörper binden können. Dies ist bei Makromolekülen, wie z. B. Proteinen, möglich. Der Detektionsantikörper ist entweder enzymmarkiert oder wird durch einen weiteren, enzymmarkierten Antikörper nachgewiesen. Durch Zugabe des Substrats wird mittels der enzymkatalysierten Farbstoffreaktion die Antigenkonzentration messbar. Durch Einsatz eines sekundären, enzymgekoppelten Antikörpers wird ein enzymgekoppelter, antigenspezifischer Antikörper vermieden. Der zweite Antikörper ist ein polyklonaler Antikörper gegen den Fc-Bereich des ersten Antikörpers, er ist somit breiter einsetzbar und zudem auch kostengünstig. 
Alle beschriebenen ELISA-Methoden sind heute sichere und einfach durchführbare Routineverfahren mit hoher Spezifität, und stellen ein wertvolles diagnostisches Mittel in einfach ausgestatteten Laboren insbesondere in weniger entwickelten Ländern dar. Die Vorteile der ELISA-Nachweisverfahren im Einzelnen nach Crowther (2000) sind: Einfachheit: Die Durchführung ist einfach und schnell zu erlernen. Das gefärbte Endprodukt kann auch mittels bloßen Auges abgelesen werden. Schnelligkeit: Der Test kann innerhalb von wenigen Stunden ausgeführt werden. Empfindlichkeit: Detektionskonzentrationen von 0,01 bis 1 $\mu \mathrm{g} / \mathrm{ml}$ sind erzielbar. Vielseitigkeit: Es existieren verschiedene ELISA-Methoden. Dies ist wichtig bei der Entwicklung neuer Tests und in der Forschung. Kosten: Die Kosten der Reagenzien sind gering. Gefahrlosigkeit: Es kommen sichere, nicht mutagene Reagenzien zum Einsatz. Verfügbarkeit: ELISAs können überall durchgeführt werden, auch in weniger gut ausgestatteten Laboren. Die benötigten Reagenzien sind im Handel erhältlich. Standardisierbarkeit: Sie ist gegeben durch die gute Quantifizierbarkeit der Ergebnisse.

Zusammenfassend bleibt festzuhalten, dass die leichte Handhabung, die schnelle photometrische Auswertung der Messergebnisse sowie die hohe Sensitivität den ELISA zu einem optimalen Screeningtest in der Routinediagnostik machen. Aufgrund der hohen Flexibilität und des großen Probendurchsatzes eignet sich dieses Nachweisverfahren insbesondere für seroepidemiologische Studien.

\subsubsection{Bewertung von Nachweismethoden: Sensitivität und Spezifität}

Mit Sensitivität und Spezifität werden zwei grundlegende Leistungsmerkmale bezeichnet, die zur Bewertung eines Testverfahrens herangezogen werden (Abbildung 5). Die bei der

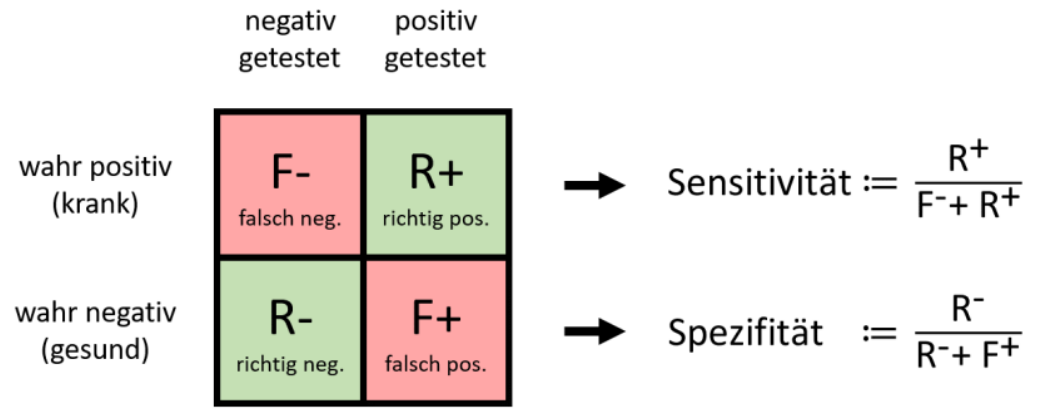

Abbildung 5: Definition von Sensitivität und Spezifität 
Testmessung eines bekannten Probensatzes erreichte Sensitivität berechnet sich aus der Zahl der korrekt positiven Ergebnisse, geteilt durch die Gesamtzahl aller tatsächlich positiven Proben $\left(\mathrm{R}^{+}+\mathrm{F}^{-}\right.$, Abbildung 5). Sensitivität ist ein Maß für das Nachweisvermögen einer Methode: Je geringer die Konzentration eines Stoffes in einer zu untersuchenden Probe ist, die noch vom Leerwert unterschieden werden kann, desto sensitiver ist diese Methode. In die Sensitivität fließt jedoch nicht die Zahl der falsch positiv detektierten Proben ein, diese werden über die Spezifität erfasst.

Die bei der Testmessung eines bekannten Probensatzes erreichte Spezifität berechnet sich aus der Zahl der korrekt negativen Ergebnisse, geteilt durch die Gesamtzahl aller tatsächlich negativen Proben $\left(\mathrm{R}^{-}+\mathrm{F}^{+}\right.$, Abbildung 5). Eine hohe Spezifität erlaubt die qualitative oder quantitative Erfassung einer einzigen Substanz unter Ausschluss anderer Komponenten. Die Spezifität macht jedoch keine Aussage darüber, ob tatsächlich auch alle positiven Proben erfasst werden. Eine Kombination von 100\% Sensitivität (alle positiven Proben werden korrekt erfasst) und 100\% Spezifität (alle negativen Proben werden korrekt erfasst) ist in der Praxis nicht erreichbar.

\subsection{Zielsetzung}

Das RVF ist in zahlreichen Ländern, insbesondere Afrikas, endemisch. Es tritt bei Menschen und Nutztieren epidemisch auf und stellt daher eine große human- und veterinärmedizinische Herausforderung dar. Zudem fehlt momentan ein Testverfahren, mit dem sowohl Patienten- als auch Nutztierseren speziesunabhängig und zuverlässig auf RVFVInfektionen getestet werden können.

Das Ziel der vorliegenden Arbeit ist daher die Etablierung eines speziesunabhängigen ELISAs hoher Sensitivität und Spezifität zur Detektion von RVFV-Antikörpern. Derzeit werden zur Detektion von RVFV mittels ELISA zwei Testverfahren eingesetzt: Ein indirekter ELISA, bei dem speziesspezifische Antikörper verwendet werden müssen, sowie ein kompetitiver ELISA, der zwar speziesunabhängig funktioniert, jedoch viel Serum benötigt und relativ unempfindlich ist. Der neu entwickelte Test soll die Vorteile des kompetitiven ELISAs (Speziesunabhängigkeit) und des indirekten ELISAs (hohe Sensitivität und Spezifität) durch 
Verwendung eines enzymgekoppelten Antigens anstelle des enzymgekoppelten Sekundärantikörpers miteinander verbinden. Die Sensitivität und Spezifität des neuen Tests sollen mit Hilfe von Immunfluoreszenzanalyse als Referenzmethode ermittelt und mit den etablierten ELISA-Verfahren verglichen werden. 


\section{Material und Methoden}

\subsection{Standardmaterialien}

Im Folgenden sind regelmäßig in den Versuchen verwendete Materialien aufgelistet, die als Standardmaterialien bezeichnet werden:

Tabelle 1: Standardmaterialien

\begin{tabular}{|c|c|}
\hline \multicolumn{2}{|l|}{ Geräte } \\
\hline $\mathrm{CO}_{2}$-Inkubator & Heraeus Sepatech GmbH, Osterode, Deutschland \\
\hline Gefrierschrank $\left(-20^{\circ} \mathrm{C}\right)$ & Liebherr GmbH, Ochsenhausen, Deutschland \\
\hline Inkubator & Heraeus Sepatech GmbH, Osterode, Deutschland \\
\hline Kühlschrank $\left(5^{\circ} \mathrm{C}\right)$ & Liebherr GmbH, Ochsenhausen, Deutschland \\
\hline Sterilbank & Heraeus Sepatech GmbH, Osterode, Deutschland \\
\hline Varifuge RI & Heraeus Instruments GmbH, Hannover, Deutschland \\
\hline Multipette & Eppendorf AG, Hamburg, Deutschland \\
\hline Vortex & Bender \& Hobein AG, Zürich, Schweiz \\
\hline Zentrifuge & Eppendorf AG, Hamburg, Deutschland \\
\hline Zentrifuge (Megafuge 1.0R) & Thermo Scientific, Rockford, USA \\
\hline Gefrierschrank $\left(-80^{\circ} \mathrm{C}\right)$ & Thermo Scientific, Rockford, USA \\
\hline Mehrkanalpipette $50-200 \mu \mathrm{l}$ & Eppendorf AG, Hamburg, Deutschland \\
\hline Waage & Sartorius AG, Göttingen, Deutschland \\
\hline \multicolumn{2}{|l|}{ Verbrauchsartikel } \\
\hline $\begin{array}{l}\text { Gewebekulturflaschen mit Filter } \\
\left(75 \mathrm{~cm}^{2}\right)\end{array}$ & Greiner Bio-One GmbH, Frickenhausen, Deutschland \\
\hline Handschuhe (Latex) & Mikroflex Corporation, Wien, Österreich \\
\hline Mikroschraubgefäße $(2,0 \mathrm{ml})$ & Sarstedt AG \& Co, Nümbrecht, Deutschland \\
\hline Pipette & Eppendorf AG, Hamburg, Deutschland \\
\hline $\begin{array}{l}\text { Pipetten mit Spitzen }(2 \mathrm{ml}, 5 \mathrm{ml}, 10 \mathrm{ml} \text {, } \\
25 \mathrm{ml})\end{array}$ & $\begin{array}{l}\text { Hirschmann Laborgeräte GmbH \& Co. KG, Eberstadt, } \\
\text { Deutschland }\end{array}$ \\
\hline $\begin{array}{l}\text { Pipettenspitzen mit Filter } \\
(0,1-10 \mu \mathrm{l}, 1,0-100 \mu \mathrm{l}, 101-1000 \mu \mathrm{l})\end{array}$ & Starlab GmbH, Ahrensberg, Deutschland \\
\hline Pipettus & $\begin{array}{l}\text { Hirschmann Laborgeräte GmbH \& Co. KG, Eberstadt, } \\
\text { Deutschland }\end{array}$ \\
\hline Röhrchen (15 ml, 50 ml) & Sarstedt AG \& Co, Nümbrecht, Deutschland \\
\hline $\begin{array}{l}\text { Safe-Lock-Reaktionsgefäße } \\
(0,5 \mathrm{ml}, 1,5 \mathrm{ml}, 2 \mathrm{ml})\end{array}$ & Eppendorf AG, Hamburg, Deutschland \\
\hline $\begin{array}{l}\text { Vernichtungsbeutel ( } 300 \mathrm{~mm} \mathrm{x} \\
200 \mathrm{~mm} \text { ) }\end{array}$ & Lab Logistic Group GmbH, Meckenheim, Deutschlano \\
\hline Labortücher $(20,5 \mathrm{~cm} \times 20,0 \mathrm{~cm})$ & Kimberly- Clark Europe Limited, Kings Hill, UK \\
\hline
\end{tabular}




\section{Medien und Puffer}

DMEM

DMEM (gebrauchsfertig) c.c.pro GmbH, Oberdorla, Deutschland

$500 \mathrm{ml}$ DMEM, $50 \mathrm{ml} \mathrm{FKS,} 100 \mathrm{U} / \mathrm{ml}$ Penicillin, 100 \%g/ml Streptomycin, 526,6 mg/l Glutamin

c.c.pro $\mathrm{GmbH}$, Oberdorla, Deutschland

\subsection{Biochemische Methoden}

\subsubsection{Protein-Expression in $E$. coli}

Tabelle 2: Materialien

\begin{tabular}{|c|c|}
\hline Standardmaterialien & Siehe Seite 20 \\
\hline \multicolumn{2}{|l|}{ Geräte } \\
\hline Bakterienbrutschrank & Heraeus Instruments GmbH, Hannover, Deutschland \\
\hline Schüttelinkubator (Certomat H) & Sartorius AG, Göttingen, Deutschland \\
\hline Nano Drop ND-1000 Spektralphotometer & Thermo Scientific, Rockford, USA \\
\hline $\begin{array}{l}\text { Sonden-Ultraschallgerät (Branson } \\
\text { Sonifier 250) }\end{array}$ & Branson \\
\hline \multicolumn{2}{|l|}{ Verbrauchsartikel } \\
\hline Parafilm & American National Can, Chicago, USA \\
\hline \multicolumn{2}{|l|}{ Chemikalien } \\
\hline Ampicillin & Roche Diagnostics GmbH, Mannheim, Deutschland \\
\hline Bacto-Agar & BD Biosciences, Heidelberg, Deutschland \\
\hline Bacto-Hefeextrakt & BD Biosciences, Heidelberg, Deutschland \\
\hline Bacto-Tryptone & BD Biosciences, Heidelberg, Deutschland \\
\hline \multicolumn{2}{|l|}{ Puffer, Lösungen, Medien } \\
\hline Luria-Bertani Medium (LB-Medium) & $\begin{array}{l}5 \text { I } 1 \% \mathrm{NaCl}, 1 \% \text { Trypton, } 0,5 \% \text { Hefeextrakt ( } 20 \mathrm{~min} \text { bei } \\
120^{\circ} \mathrm{C} \text { autoklavieren) }\end{array}$ \\
\hline LB-Agar mit Amp & $\begin{array}{l}10 \mathrm{~g} \text { Bacto-Tryptone, } 5 \mathrm{~g} \text { Bacto-Yeast Extract, } 10 \mathrm{~g} \mathrm{NaCl} \text {, } \\
1 \mathrm{ml} \text { Ampicillin [100 } \mu \mathrm{g} / \mathrm{ml} \text { ], } 15 \mathrm{~g} \text { Bacto-Agar, ad } 1 \mathrm{I} \mathrm{H} \mathrm{H}_{2} \mathrm{O}\end{array}$ \\
\hline LB-Medium mit Amp & $\begin{array}{l}10 \mathrm{~g} \text { Bacto-Tryptone, } 5 \mathrm{~g} \text { Bacto-Yeast Extract, } 10 \mathrm{~g} \mathrm{NaCl} \text {, } \\
1 \mathrm{ml} \text { Ampicillin }\left[100 \mu \mathrm{g} / \mathrm{ml} \text {, ad } 1 \mathrm{I} \mathrm{H}_{2} \mathrm{O}\right.\end{array}$ \\
\hline LB-Medium mit Amp und Kana & $\begin{array}{l}10 \mathrm{~g} \text { Bacto-Tryptone, } 5 \mathrm{~g} \text { Bacto-Yeast Extract, } 10 \mathrm{~g} \mathrm{NaCl} \text {, } \\
1 \mathrm{ml} \text { Ampicillin }[100 \mu \mathrm{g} / \mathrm{ml} \text {, } 1 \mathrm{ml} \text { Kanamycin } \\
(100 \mu \mathrm{g} / \mathrm{ml}) \text { ad } 1 \mathrm{l} \mathrm{H}_{2} \mathrm{O}\end{array}$ \\
\hline IPTG-Lösung (100 mM) & $24 \mathrm{~g}$ IPTG, ad $1 \mathrm{I} \mathrm{H}_{2} \mathrm{O}$ \\
\hline
\end{tabular}

Zur Anzucht der Bakterien und Induktion werden transformierte E.coli (M15) aus Glycerolstock mit einer sterilen Pipettenspitze gepickt, auf LB-Amp-Kana-Nährmedium ausgestrichen und über Nacht bei $37^{\circ} \mathrm{C}$ inkubiert. 
Ein Klon der mit pQE9-RVFV-His-N transformierten Bakterien in M15 wird mit 5 ml LB-AmpKana-Medium inokuliert und über Nacht bei $37{ }^{\circ} \mathrm{C}$ bei ca. $200 \mathrm{rpm}$ geschüttelt. Anschließend wird $1 \mathrm{ml}$ der Übernachtkultur in $50 \mathrm{ml}$ LB-Amp-Kana-Medium überimpft und $24 \mathrm{~h}$ bei $28^{\circ} \mathrm{C}$ inkubiert.

\subsubsection{Induktion mittels IPTG}

Isopropyl- $\beta$-D-thiogalactopyranosid (IPTG) ist ein Galactose-Thioglycosid (S-Glycosid), welches als künstlicher Induktor des Lactose-Operons in E. coli genutzt wird, um die rekombinante Expression von klonierten Genen zu einem bestimmten Zeitpunkt zu starten. Dazu werden die gewünschten Gene in Plasmid-Vektoren kloniert, deren Promoter vom Lac-Operon gefolgt wird. Dieses dient dem Lac-Repressor-Protein als Bindestelle, wodurch die Transkription des Gens zunächst verhindert wird. IPTG bindet an den Lac-Repressor, wodurch dieser einer Konformationsänderung unterzogen wird, die seine Wechselwirkung mit dem Lac-Operon inhibiert und so die Expression des Gens startet.

Dazu wurde $10 \mathrm{ml}$ der $24 \mathrm{~h}$-Kultur in $500 \mathrm{ml}$ LB-Amp-Kana-Medium über den Tag bei $28^{\circ} \mathrm{C}$ inkubiert bis eine OD von 0,5-0,7 erreicht wird. Die Messung erfolgt am Nanodrop. Vor der Induktion wird $1 \mathrm{ml}$ Kultur abgefüllt, abzentrifugiert und für die Gelauftragung eingefroren. Die Induktion erfolgt durch Zugabe von 5 ml IPTG-Lösung für eine Endkonzentration von 1 mM IPTG. Nach der Induktion wird die Flüssigkultur über Nacht bei $28^{\circ} \mathrm{C}$ und ca. $200 \mathrm{rpm}$ geschüttelt.

\subsubsection{Ernte der Bakterien}

Zur Ernte der Bakterien wird die Übernachtkultur 20 min bei $4000 \mathrm{~g}$ abzentrifugiert und mit PBS gewaschen. Der Überstand wird verworfen und das Pellet bei $-20^{\circ} \mathrm{C}$ eingefroren. Die Bakterien werden mittels Ultraschalles aufgeschlossen. Dazu wird das E. coli-Pellet in $5 \mathrm{ml}$ Puffer 1b (Tabelle 3) resuspendiert. Der Aufschluss wird mit dem Sonden-Ultraschallgerät durchgeführt. Um eine Überhitzung der Zellen zu verhindern, wird das Röhrchen zunächst auf Eis gestellt und dann sieben Mal für $30 \mathrm{~s}$ beschallt. Anschließend erfolgt die Zentrifugation bei $12000 \mathrm{~g}$ und $4{ }^{\circ} \mathrm{C}$ für $25 \mathrm{~min}$. Der Überstand wird in $15 \mathrm{ml}$ Falcon Röhrchen abpipettiert und bei $-20^{\circ} \mathrm{C}$ gelagert. 


\subsubsection{Reinigung des Proteins über die Affinitätschromatographie mittels Ni-NTA-Agarose}

Tabelle 3: Materialien

\begin{tabular}{|c|c|}
\hline Standardmaterialien & siehe Seite 20 \\
\hline \multicolumn{2}{|l|}{ Geräte } \\
\hline Rotator & Snijders, Tilburg, Niederlande \\
\hline \multicolumn{2}{|l|}{ Verbrauchsartikel } \\
\hline $\begin{array}{l}\text { Chromatographie Säule Poly-Prep } 0,8 \\
\text { x } 4 \mathrm{~cm}\end{array}$ & Bio-Rad \\
\hline \multicolumn{2}{|l|}{ Chemikalien } \\
\hline Ni-NTA-Agarose & Qiagen \\
\hline \multicolumn{2}{|l|}{ Puffer, Lösungen, Medien } \\
\hline \multirow[t]{6}{*}{ Puffer A für $1 \mathrm{I}$} & $50 \mathrm{mM}$ Tris (pH 8,0) - $50 \mathrm{ml} 1 \mathrm{M}$ Tris-Stammlösung $(\mathrm{pH} 8,0)$ \\
\hline & 500 mM NaCl - 100 ml 5 M NaCl-Stammlösung \\
\hline & 5 mM MgCl-Einwaage: 1,016 g \\
\hline & $10 \%$ Glycerin $100 \mathrm{ml}$ \\
\hline & 0,1\% NP-40 Alternative $1 \mathrm{ml}$ \\
\hline & 2 mM Imidazol-Einwaage: 0,136 g \\
\hline \multirow[t]{4}{*}{ Ansatz direkt vor Gebrauch } & Puffer 1: $40 \mathrm{ml}$ Puffer A + 19,6 $\mu \mathrm{l}$ ß-Mercaptoethanol \\
\hline & 1a: ohne PMSF \\
\hline & 1b: 20 ml Puffer $1+20 \mu$ I PMSF (Stock: 100 mM) auf Eis (!) \\
\hline & $\begin{array}{l}\text { Puffer 2: } 20 \mathrm{ml} \text { Puffer } A+9,8 \mu \mathrm{l} \beta \text {-Mercaptoethanol + } 560 \mu \mathrm{l} \\
\text { Imidazol-Stammlösung ( } 1 \mathrm{M})\end{array}$ \\
\hline \multirow[t]{5}{*}{ Elutionspuffer: für $500 \mathrm{ml}$} & $20 \mathrm{mM}$ Tris $(\mathrm{pH} \mathrm{8,0)} 10 \mathrm{ml}$ Stammlösung \\
\hline & 100 mM NaCl 10 ml Stammlösung \\
\hline & $5 \mathrm{mM} \mathrm{MgCl}$ Einwaage: 0,508 g \\
\hline & $20 \%$ Glycerin $100 \mathrm{ml}$ \\
\hline & $0,1 \%$ NP-40 Alternative $-0,5 \mathrm{ml}$ \\
\hline \multirow[t]{2}{*}{ Ansatz direkt vor Gebrauch } & $\begin{array}{l}\text { Puffer 3a: } 100 \text { ml Elutionspuffer }+200 \mu l \text { Imidazol } \\
\text { (Stammlösung) }\end{array}$ \\
\hline & Puffer 3b: $100 \mathrm{ml}$ Elutionspuffer $+1,7 \mathrm{~g}$ Imidazol (= $270 \mathrm{mM})$ \\
\hline
\end{tabular}

Die Affinitätschromatographie ist eine Methode zur Isolation eines Stoffes aus einer Lösung mit Hilfe einer spezifischen Ligand/Analyt-Wechselwirkung. Im Falle der eingesetzten Nickelchelat-Affinitätschromatographie werden Proteine mit Polyhistidinpeptid-Schwanz an eine stationäre Phase aus quervernetztem Agarosegel mittels eines $\mathrm{Ni}^{2+}$ Nitrilotriessigsäure-Chelats (Ni-NTA) spezifisch gebunden. Zur Aufreinigung des mit einem C-terminalen Hexahistidinpeptid-Schwanz versehenen RVFV-N-Proteins (His-tagged RVFV- 
N-Protein) aus 2.1.1 wird das Protein-Agarosegel-Gemisch auf eine Trennsäule gegeben. Mehrere Waschschritte dienen der Entfernung unspezifisch gebundener Stoffe, die mit dem Ni-NTA-Liganden keine Bindung eingehen. Die abschließende Eluation des gebundenen RVFV-N-Proteins wird durch Verdrängung der Polyhistidinreste durch Imidazol erreicht.

Zur Reinigung der 1,4 ml Ni-NTA-Agarose wird vorbereitend pro 0,5 I Übernachtkultur 2x mit je $10 \mathrm{ml}$ Bidest gewaschen, danach 2x mit $10 \mathrm{ml}$ Puffer 1a. Anschließend wird die Agarose jeweils für $4 \mathrm{~min}$ bei $400 \mathrm{rpm}$ zentrifugiert, der Überstand wird verworfen. Der Überstand der zentrifugierten Bakteriensuspension wird auf die äquilibrierte Agarose gegeben und mind. $2 \mathrm{~h}$ im Kühlraum über Kopf geschwenkt.

Daraufhin erfolgt die Zentrifugation der Bakteriensuspension für 4 min bei $400 \mathrm{rpm}$, der Überstand wird verworfen und die Agarose mit $1 \mathrm{ml}$ Puffer 2 resuspendiert und in eine Biorad-Leersäule überführt. Die Puffer werden verworfen und die Säule zunächst mit $20 \mathrm{ml}$ Puffer 2, anschließend mit $10 \mathrm{ml}$ Puffer 3a gewaschen. Abschließend erfolgt die Eluation jeweils mit 8x $500 \mu \mathrm{l}$ Puffer 3b. Es folgt die Lagerung der Eluate bei $4{ }^{\circ} \mathrm{C}$.

\subsubsection{Auftrennung der Proteine durch SDS-Polyacrylamid- Gelelektrophorese}

Tabelle 4: Materialien

\begin{tabular}{|c|c|}
\hline Standardmaterialien & siehe Seite 20 \\
\hline \multicolumn{2}{|l|}{ Geräte } \\
\hline Heizblock (Thermomixer) & Eppendorf AG, Hamburg, Deutschland \\
\hline Proteingelkammer & Bio Rad Laboratories GmbH, München, Deutschland \\
\hline \multicolumn{2}{|l|}{ Nukleotide, Standards } \\
\hline $\begin{array}{l}\text { Molekulargewichtsmarker (10- } \\
170 \mathrm{kDa})\end{array}$ & Fermentas GmbH, Leon-Rot, Deutschland \\
\hline \multicolumn{2}{|l|}{ Chemikalien } \\
\hline$\beta-$ Mercaptoethanol & Merck KGaA, Darmstadt, Deutschland \\
\hline Acrylamid-Bisacrylamid-Lösung (40\%) & Serva Electrophoresis GmbH, Heidelberg, Deutschland \\
\hline Amidoschwarz & TMC- Bio Products, Rockland, USA \\
\hline Natriumlaurylsulfat (SDS) & Carl Roth GmbH + Co. KG, Karlsruhe, Deutschland \\
\hline $\begin{array}{l}\mathrm{N}, \mathrm{N}, \mathrm{N}^{\prime}, \mathrm{N}^{\prime} \text {-Tetramethylethylendiamin } \\
\text { (TEMED) }\end{array}$ & Sigma-Aldrich Chemie GmbH, Steinheim, Deutschland \\
\hline Tris-Base & Carl Roth GmbH + Co. KG, Karlsruhe, Deutschland \\
\hline
\end{tabular}




\begin{tabular}{|c|c|}
\hline Puffer, Lösungen, Medien & \\
\hline Amidoschwarzlösung & $50 \mathrm{mg}$ Amidoschwanz gelöst in $112 \mathrm{ml}$ Methanol, $113 \mathrm{ml} \mathrm{H} \mathrm{H}_{2} \mathrm{O}$ \\
\hline APS [10\%] & $1 \mathrm{~g}$ Ammoniumperoxodisulfat (APS), ad $100 \mathrm{ml} \mathrm{H} \mathrm{H}_{2}$ \\
\hline Laufpuffer (SDS-PAGE) & $100 \mathrm{ml}$ TGS [10x], $10 \mathrm{ml}$ SDS [10\%], ad 1 I $\mathrm{H}_{2} \mathrm{O}$ \\
\hline Sammelgel [12\%] (SDS-PAGE) & $\begin{array}{l}0,25 \mathrm{ml} \text { Acrylamid-Bis [40\%], 0,325 ml Tris pH 6,8 [1 M], 1,85 ml } \\
\mathrm{H}_{2} \mathrm{O}, 25 \mu \mathrm{l} \text { SDS [10\%], } 25 \mu \mathrm{l} \text { APS [10\%], 2,5 } \mu \mathrm{l} \text { TEMED }\end{array}$ \\
\hline SDS [10\%] & $100 \mathrm{~g}$ SDS, ad $1 \mathrm{I} \mathrm{H}_{2} \mathrm{O}$ \\
\hline Trenngel [12\%] (SDS-PAGE) & $\begin{array}{l}2 \mathrm{ml} \text { Acrylamid-Bis [40\%], 1,88 ml Tris pH 8,8 [1 M], 1,03 } \mathrm{ml} \mathrm{H}_{2} \mathrm{O} \text {, } \\
50 \mu \mathrm{l} \text { SDS [10\%], } 50 \mu \mathrm{l} \text { APS [10\%], } 5 \mu \mathrm{l} \text { TEMED }\end{array}$ \\
\hline Tris pH 6,8 [1 M] & $121,14 \mathrm{~g}$ Tris, ad $1 \mathrm{I} \mathrm{H}_{2} \mathrm{O}, \mathrm{pH}-$ Wert einstellen mit $\mathrm{HCl}$ \\
\hline Probenpuffer & Laemmli Sample Buffer $190 \mu \mathrm{l}$ mit $10 \mu \mathrm{l} \beta$-Mercaptoethanol \\
\hline Tris pH 8,8 [1 M] & $121,14 \mathrm{~g}$ Tris, ad $1 \mathrm{l} \mathrm{H}_{2} \mathrm{O}, \mathrm{pH}-$ Wert einstellen mit $\mathrm{HCl}$ \\
\hline
\end{tabular}

Die Gelelektrophorese ist eine analytische Methode, um Proteine ihrer molekularen Größe und Ionenladung nach aufzutrennen. Dabei wandern im statischen elektrischen Feld die positiv geladenen Moleküle in einer Pufferlösung durch die Maschen einer Gelmatrix zur Anode und die negativ geladenen Moleküle zur Kathode. Proteine als Zwitterionen verhalten sich im elektrischen Feld zunächst neutral, d. h. sie bleiben stationär. Durch das Beladen mit negativer Ladung mittels Natriumdodecylsulfat (SDS, ca. 1,4 g SDS pro $1 \mathrm{~g}$ Protein) wird die positive Eigenladung der Proteine bedeckt, so dass diese als nunmehr negativ geladene Moleküle aufgetrennt werden können.

Die SDS-PAGE ist eine diskontinuierliche Gelelektrophorese. Die Gelmatrix besteht aus Sammelgel und Trenngel, die Diskontinuität besteht im unterschiedlichen $\mathrm{pH}$-Wert der Puffer (Gelpuffer, Elektrodenpuffer) und der Porengröße der Gele. Die Wandergeschwindigkeit der Moleküle im Separationsgel ist abhängig von ihrem Molekularradius, große Moleküle durchqueren das Gel langsamer als kleine. Um die beste Auftrennung zu erhalten, sollten die kleinsten, mobilsten Moleküle das Ende des Gels erreicht haben.

Mehrere Proben (Banden) können parallel durch das Gel laufen. Zur präzisen Bestimmung des Molekulargewichts dienen Molekularmassenstandards. Für reproduzierbare Ergebnisse müssen Temperatur und Konzentration der Pufferlösungen konstant gehalten werden. 
Zur Probenvorbereitung die Proben (1-8) mit Probenpuffer 1:1 verdünnen (10 $\mu \mathrm{l}$ Probe +10 $\mu$ Probenpuffer), 10 min bei $95^{\circ} \mathrm{C}$ aufkochen und kurz abzentrifugieren, danach auf Eis stellen. Anschließend pro verwendetem Gel-Slot $20 \mu$ l Probe bzw. $5 \mu$ les Protein-Markers (Page-Ruler) mittels Hamilton-Spritze einfüllen. Die Proben mit einer Spannung von $60 \mathrm{~V}$ in das Sammelgel laufen lassen, ab dem Trenngel die Spannung auf $100 \mathrm{~V}$ erhöhen. Die Gesamtlaufzeit des Gels beträgt $2 \mathrm{~h}$.

\subsubsection{Transfer der Proteine auf die PVDF-Membran (Western Blot)}

Tabelle 5: Materialien

\begin{tabular}{|c|c|}
\hline Standardmaterialien & siehe Seite 20 \\
\hline \multicolumn{2}{|l|}{ Geräte } \\
\hline Chemidoc XRS System & Bio Rad Laboratories GmbH, München, Deutschland \\
\hline Westernblotkammer & Bio Rad Laboratories $\mathrm{GmbH}$, München, Deutschland \\
\hline Wippe & Schuett24 GmbH, Göttingen, Deutschland \\
\hline \multicolumn{2}{|l|}{ Verbrauchsartikel } \\
\hline PVDF-Membran (0,3 x 3,0 m Rolle) & Amersham Biosciences Europe $\mathrm{GmbH}$, Freiburg, Deutschland \\
\hline Filterpapier & Whatman GmbH, Dassel, Deutschland \\
\hline \multicolumn{2}{|l|}{ Chemikalien } \\
\hline Methanol & Merck KGaA, Darmstadt, Deutschland \\
\hline Difo Magermilchpulver & BD Biosciences, Heidelberg, Deutschland \\
\hline Tween 20 & Sigma-Aldrich Chemie $\mathrm{GmbH}$, Steinheim, Deutschland \\
\hline \multicolumn{2}{|l|}{ Puffer, Lösungen, Medien } \\
\hline Blockierungspuffer (Western Blot) & 12 g Magermilchpulver, 120 ml Waschpuffer (Western Blot) \\
\hline Transferpuffer (Western Blot) & 3 g Tris, 14,4 g Glycin, ad 1 I $\mathrm{H}_{2} \mathrm{O}$ \\
\hline Waschpuffer (Western Blot) & $100 \mathrm{ml}$ PBS [10X], $5 \mathrm{ml}$ Tween 20, ad $1 \mathrm{I} \mathrm{H}_{2} \mathrm{O}$ \\
\hline $\begin{array}{l}\text { Amersham ECL Plus Western Blotting } \\
\text { Detection System }\end{array}$ & GE Healthcare Europe NV, Brüssel, Belgien \\
\hline
\end{tabular}

Zum immunologischen Nachweis werden Proteine nach der elektrophoretischen Auftrennung mittels SDS-PAGE (2.2.3) auf eine Polyvinylidenfluorid-Membran (PVDFMembran) transferiert. Diese werden mittels, primären Antikörper und sekundären mit Enzym gekoppelten Antikörper spezifisch nachgewiesen. Das Enzym MeerrettichPeroxidase, (horseradish-peroxidase, HRP) katalysiert die Umsetzung von Luminol in seine oxidierte Form, dessen Lumineszenz detektiert wird. 
Dazu werden das Filterpapier und die PVDF-Membran auf Trenngel-Größe zurechtgeschnitten, die Membran in Methanol eingeweicht und mit Wasser abgespült. Die Transferapparatur wird in einer Schale mit Transferpuffer wie folgt von Kathode nach Anode zusammengesetzt: Schwarze Seite der Transferkassette - Schwamm - Filterpapier - Gel PVDF-Membran - Filterpapier - Schwamm - durchsichtige Seite der Transferkassette. Anschließend wird die Kassette geschlossen und der Farbe entsprechend eingehängt. Der Transfer erfolgt bei 350 mA für $1 \mathrm{~h}$ unter Rühren und Kühlen des Puffers. Zum Blocken der unspezifischen Bindungsstellen wird die Membran in Blocking Lösung für $1 \mathrm{~h}$ bei RT auf einem Taumler inkubiert und anschließend bei $4{ }^{\circ} \mathrm{C}$ über Nacht gelagert. Am darauffolgenden Tag erfolgt die Färbung der Membran:

Dazu wird die Membran 1x mit Waschpuffer gespült, dann mit $10 \mathrm{ml}$ Primär-Ak-Lösung (Anti-RVFV-N aus Ziege 1:250 in Blocking Lösung) 1h bei RT inkubiert und anschließend $3 \times 10$ min auf dem Taumler gewaschen.

Dann erfolgt die Inkubation der Membran mit $10 \mathrm{ml}$ Sekundär-Ak-Lösung (Anti-goat-IgG 1:250 in Blocking Lösung) für $1 \mathrm{~h}$ bei RT. Anschließend wird die Membran 3x10 min auf dem Taumler gewaschen.

Die Detektion der Antikörper-markierten Banden erfolgt mittels ECL Plus Western Blotting Detektionsreagenzien (GE Healthcare) nach Vorgabe des Herstellers. Die Aufnahme und Auswertung erfolgte dabei mit Hilfe eines Biorad Chemidoc XRS Imagers, sowie des zugehörigen Programms Quantity One.

\subsubsection{Dialyse der eluierten RVFV-N-Proteinlösung}

Dialyse bezeichnet den Austausch gelöster Stoffe über eine semipermeable Membran. Zum Ersetzen des RVFV-N-Eluationspuffers durch PBS wird eine Slide-A-Lyzer Dialysierkasette mit einem Fassungsvolumen von 0,5-3 ml und einer Ausschlussgrenze (Molecular Weight Cut Off, MWCO) von 3500 Da verwendet.

Dazu werden die Eluate 2 bis 5 in die vorhydratisierte Kassette luftblasenfrei pipettiert und bei RT dialysiert. Hierbei wird zunächst $2 \mathrm{x}$ nach je $2 \mathrm{~h}$ der PBS Puffer gewechselt, und die 
Dialyse anschließend bei $4{ }^{\circ} \mathrm{C}$ über Nacht fortgesetzt. Darauffolgend wird die Proteinlösung mit einer Pipette vorsichtig aus der Kassette entnommen und bei $4{ }^{\circ} \mathrm{C}$ gelagert.

\subsubsection{Färbung von Proteingelen}

Tabelle 6: Materialien

\begin{tabular}{ll}
\hline Standardmaterialien & siehe Seite 20 \\
\hline $\begin{array}{l}\text { Geräte } \\
\text { Wippe }\end{array}$ & Schuett24 GmbH, Göttingen, Deutschland \\
\hline $\begin{array}{l}\text { Puffer, Lösungen, Medien } \\
\text { Coomassie-Färbelösung }\end{array}$ & $\begin{array}{l}0,1 \%(\mathrm{w} / \mathrm{v}) \text { Serva blue R (Coomassie brilliant blue R-250), } 25 \% \\
(\mathrm{v} / \mathrm{v}) \text { Isopropanol, } 10 \%(\mathrm{v} / \mathrm{v}) \text { Essigsäure, } 65 \%(\mathrm{v} / \mathrm{v}) \mathrm{ddHO}\end{array}$ \\
Entfärbelösung & $50 \%(\mathrm{v} / \mathrm{v})$ Methanol, $10 \%(\mathrm{v} / \mathrm{v})$ Essigsäure, $40 \%(\mathrm{v} / \mathrm{v}) \mathrm{ddH}_{2} \mathrm{O}$
\end{tabular}

Der Farbstoff „Coomassie brilliant blue R-250“ bindet an die Proteine, dadurch werden die Proteine durch blaue Banden sichtbar. Der Messbereich beträgt 0,1-5,0 mg/ml Protein. Für geringere Proteinkonzentration ist dieses Verfahren nicht geeignet. Die Probe sollte detergenzienfrei sein, da sonst die Bildung des Farbkomplexes behindert wird. Mittels der Coomassie-Färbung können in Polyacrylamidgelen aufgetrennte Proteine mit einer Nachweisgrenze von 0,1 $\mu \mathrm{g}$ detektiert werden.

Dazu werden die Gele $1 \mathrm{~h}$ lang in der Coomassie-Färbelösung geschwenkt, anschließend in Entfärberlösung inkubiert und über Nacht in $\mathrm{ddH}_{2} \mathrm{O}$ äquilibriert. Die Trocknung der Gele erfolg für $3 \mathrm{~h}$ in Cellophan-Folie im Geltrockner.

\subsubsection{Bestimmung der Proteinkonzentration}

Tabelle 7: Materialien

\begin{tabular}{ll}
\hline Standardmaterialien & siehe Seite 20 \\
\hline Geräte & BMG Labtech \\
$\begin{array}{l}\text { Microplate-Reader, Fluostar Optima } \\
\text { Verbrauchsmaterialien }\end{array}$ & Greiner, F Boden \\
96 Kavitäten-Platte Microlon & \\
\hline $\begin{array}{l}\text { Reagenziensätze } \\
\text { BCA Protein Assay Kit „High-Range“ }\end{array}$ & Pierce
\end{tabular}


Der BCA Test ist für die Bestimmung von Proteinmengen im Bereich von 20-2000 $\mu \mathrm{l} / \mathrm{ml}$ geeignet. Im Reagenz befinden sich $\mathrm{Cu}^{2+}$-Ionen in alkalischer Lösung, die durch Proteine zu $\mathrm{Cu}^{1+}$ im Zuge einer Biuret-Reaktion reduziert werden. Die $\mathrm{Cu}^{1+}$-Ionen bilden in einem zweiten Schritt mit Bicinchonininsäure (BCA) einen violetten Komplex. Die Proteinkonzentration kann somit über eine Absorptionsmessung ermittelt werden.

Zur Bestimmung der genauen Proteinkonzentration wird eine Standard-BSA Reihe mittels Pierce BCA Protein Assay Kit „High-Range“ aufgetragen. Die Durchführung erfolgt in 96Kavitäten Platte mit klarem Flachboden. Die BSA-Standards S1-S8 und Working-Reagents nach Gebrauchsanleitung vorbereiten. Nach 30 min Inkubation bei $37{ }^{\circ} \mathrm{C}$ erfolgt die Messung der Absorption bei $560 \mathrm{~nm}$. Die Auswertung erfolgt über eine Standard-Kurve, der Messbereich ist von 20-2000 $\mathrm{\mu l} / \mathrm{ml}$ und die Proteinkonzentration ist in den Proben direkt in Einheiten von $\mu \mathrm{g} / \mathrm{ml}$ ablesbar.

\subsubsection{RVFV-N/HRP-Konjugation mit HRP}

Tabelle 8: Materialien

\begin{tabular}{ll}
\hline Standardmaterialien & siehe Seite 20 \\
\hline Reagenziensätze & \\
EZ-Link Plus Activated Peroxidase & Thermo Scientific
\end{tabular}

Zur Gewinnung eines enzymatisch aktiven Konjugats wird das Enzym Meerrettichperoxidase (horseradish peroxidase, HRP) an das RVFV-N-Protein gebunden. Zu diesem Zweck wird Aldehyd-aktiviertes HRP eingesetzt, das bereits eine reaktive AldehydGruppe ( $\mathrm{R}-\mathrm{CHO})$ besitzt, die mit primären Aminen $\left(\mathrm{R}-\mathrm{NH}_{2}\right)$ des $\mathrm{N}$-Proteins zunächst eine Schiff'sche Base bilden. Diese wird daraufhin mittles Natriumcyanoborohydrid $\left(\mathrm{NaCNBH}_{3}\right)$ zu einer stabilen sekundären Amin-Brücke reduziert.

Zur Proteinkonjugation wird $1 \mathrm{ml}$ RVFV-N (Proteinkonzentration $250 \mu \mathrm{g}$ pro $\mathrm{ml}$ ) der Iyophilisierten Peroxidase zugegeben, anschließend $10 \mu \mathrm{l} \mathrm{NaCNBH}_{3}$ unter dem Abzug hinzugefügt und $1 \mathrm{~h}$ bei RT inkubiert. Abschließend erfolgt die Reaktion mit $20 \mu \mathrm{l}$ Quenching Puffer für 15 min bei RT. Die Lagerung des Konjugates erfolgt bei $4{ }^{\circ} \mathrm{C}$. 
Im Anschluss an die Kopplungsreaktion zwischen RVFV-N-Protein und HRP erfolgt die Aufreinigung des konjugierten Proteins über Ni-NTA-Agarose (2.2.2) sowie die Bestimmung seiner Konzentration mittels BCA (2.2.7).

\subsubsection{Messung der HRP-Aktivität}

Tabelle 9: Materialien

\begin{tabular}{|c|c|}
\hline Standardmaterialien & siehe Seite 20 \\
\hline \multicolumn{2}{|l|}{ Geräte } \\
\hline Microplate-Reader, Fluostar Optima & BMG Labtech \\
\hline \multicolumn{2}{|l|}{ Verbrauchsmaterialien } \\
\hline Mikrotiter-Platte, Microcolon & Greiner, F Boden \\
\hline Substrat, TMB & Sigma \\
\hline \multicolumn{2}{|l|}{ Lösungen, Medien und Puffer } \\
\hline Stopplösung, Schwefelsäure $1 \mathrm{M}$ & Sigma \\
\hline PBS [1x] & $100 \mathrm{ml} \mathrm{PBS}[10 \mathrm{X}]$, ad $900 \mathrm{ml} \mathrm{H} \mathrm{H}_{2} \mathrm{O}$ \\
\hline \multicolumn{2}{|c|}{ Zunächst wird farbloses TMB-Substrat (Tetramethylbenzidin) dem Eluat zugegeben. Durch } \\
\hline \multicolumn{2}{|c|}{ die Peroxidase erfolgt nun die enzymatische Reaktion, mittels derer eine dunkelblaue } \\
\hline \multicolumn{2}{|c|}{$\begin{array}{l}\text { Färbung entsteht. Diese Farbreaktion wird durch die Zugabe von Schwefelsäure gestoppt, } \\
\text { die das Enzym (HRP) denaturiert. Aus der Veränderung des pH-Wertes resultiert ein zweiter }\end{array}$} \\
\hline \multicolumn{2}{|c|}{ die das Enzym (HRP) denaturiert. Aus der Veränderung des pH-Wertes resultiert ein zweiter } \\
\hline Farbumschlag von blau nach & sorption der Lösung wird photometrisch \\
\hline
\end{tabular}

Für jedes Eluat wird ein Doppelansatz in 1:50 Verdünnung in PBS angesetzt, hierbei werden je $50 \mu$ l pro Kavität pipettiert. Nach Zugabe von jeweils $50 \mu$ l Substrat wird der Ansatz 5 min lang inkubiert. Schließlich wird die Farbreaktion mittels Zugabe von $100 \mu$ l Schwefelsäure gestoppt und die Probe mittels eines Spektralphotometers ausgewertet.

Für die Langzeitlagerung des RVFV-N-HRP-Konjugats wird die Konjugatlösung mit Glycerol im Verhältnis $1: 1$ gemischt, aliquotiert und bei $-20^{\circ} \mathrm{C}$ gelagert. 


\subsubsection{Speziesunabhängiger RVFV-N-ELISA}

Tabelle 10: Materialien

\begin{tabular}{ll}
\hline Standardmaterialien & siehe Seite 20 \\
\hline Geräte & Tecan \\
Waschgerät & Fluostar Optima (BMG Labtech) \\
Mikrotiterplatten-Lesegerät & \\
\hline Verbrauchsmaterial & Eppendorf AG, Hamburg, Deutschland \\
Safe-Lock-Reaktionsgefäße (0,5 ml, & \\
1,5 ml, 2 ml) & Microlon von Greiner, F-Boden \\
Mikrotiter-Platte & \\
\hline Chemikalien & TMB (Sigma) \\
Substrat & Carl Roth GmbH + Co. KG, Karlsruhe, Deutschland \\
Glycerin & \\
\hline Lösungen, Medien und Puffer & Schwefelsäure (Sigma) \\
Stopplösung & 100 ml PBS [10X], ad 900 ml H 20 \\
PBS [1X] & $1 x$ PBS mit 0,01\% Tween \\
Waschpuffer & Waschpuffer + 10\% Skim Milk + 5\% BSA \\
Probenpuffer & Anti-E. coli-Ak 1:1000 in Probenpuffer (für eine ganze Platte: \\
Blockingpuffer & $20 \mu$ Ak + 20 ml Probenpuffer) \\
\hline Seren &
\end{tabular}

\section{Seren}

127 Humanseren (anonymisiert)

OFA Dr. Gerhard Dobler, Institut für Mikrobiologie der Bundeswehr, München

71 Rinderseren

Abdelyahman Said, Institut für Virologie, FU Berlin

20 Rinderseren (geimpfte Tiere), 20

Prof. Mohamed A. M. Shalaby, Universität Kairo

Schafseren (geimpfte Tiere)

Die Kavitäten von Mikrotiterplatten werden über Nacht mit aufgereinigtem RVFV-N-Protein beschichtet. Restverunreinigungen der N-Protein-Lösung durch Proteine des verwendeten (E. coli) Expressionssystems können dabei zu unspezifischen Bindungsstellen führen, welche mit entsprechenden (Anti-E. coli-)Antikörpern abgesättigt werden.

Die Beschichtung der Mikrotiter-Platte mit His-tagged-RVFV-N-Protein in Verdünnung 1:250 in PBS (bei einer Ausgangskonzentration von 0,25 $\mu \mathrm{g} / \mu \mathrm{l}$ ) erfolgt jeweils mit $200 \mu \mathrm{l}$ pro Kavität. Anschließend folgt die Inkubation $1 \mathrm{~h}$ bei RT, danach über Nacht bei $4{ }^{\circ} \mathrm{C}$. Daraufhin wird die Mikrotiter-Platte 5x mit ca. $300 \mu$ l Waschpuffer pro Kavität gewaschen und unspezifische Bindungsstellen durch Inkubation für $1 \mathrm{~h}$ bei RT mit $200 \mu \mathrm{l}$ Blockingpuffer pro Kavität geblockt. 
Im ersten ELISA-Inkubationsschritt binden die nachzuweisenden Anti-RVFV-N-Antikörper aus positiven Tier- bzw. Patientenseren an die RVFV-N-Proteinschicht. Durch eine vergleichsweise niedrig eingestellte Konzentration der Antigenbeschichtung der Mikrotiterplatte wird sichergestellt, dass statistisch gesehen lediglich ein einzelner Arm eines jeden Antikörpers eine Antigen-Bindung eingehen kann: Die Mikrotiterplatte wird 5x gewaschen, anschließend erfolgt die Inkubation in Doppelansatz (100 $\mu$ l pro Kavität) von 1:100 in Probenpuffer verdünnten Proben (Seren, Blank, Positiv-/Negativkontrolle) für $1 \mathrm{~h}$ bei RT.

Im zweiten ELISA-Inkubationsschritt werden die gebundenen Anti-RVFV-N-Antikörper mit verdünntem RVFV-N-HRP-Konjugat markiert, das an den jeweils freien zweiten Arm der Antikörper bindet. Der Einsatz des konjugierten Antigens eliminiert die Notwendigkeit eines an HRP gekoppelten zweiten Antikörpers, der gegen den speziesabhängigen FcAbschnitt des ersten Antikörpers gerichtet ist: Nach 5x waschen erfolgt die Konjugation. Dazu wird die RVFV-N-HRP 1:50 in Probenpuffer verdünnt und $100 \mu$ pro Kavität für $1 \mathrm{~h}$ bei RT inkubiert.

Im dritten ELISA-Inkubationsschritt erfolgt mit Hilfe des gebundenen RVFV-N-HRPKonjugats eine Farbreaktion. Die Absorption der gefärbten Lösung ist proportional zur AntiRVFV-N-Antikörper-Konzentration im Probenserum: Die Mikrotiterplatte wird abschließend 5x gewaschen, und $100 \mu$ gebrauchsfertiges Substrat pro Kavität zeitgleich zugegeben. Die Inkubation beträgt 15 min bei RT im Dunkeln. Anschließend wird die Reaktion mit $100 \mu \mathrm{l}$ Schwefelsäure pro Kavität gestoppt und die Absorption innerhalb von 5 min mittels Microplate-Reader gemessen. 


\title{
2.3 Speziesunabhängiger RVFV-Gn-ELISA
}

\author{
Tabelle 11: Materialien
}

\begin{tabular}{|c|c|}
\hline Standardmaterialien & siehe Seite 20 \\
\hline \multicolumn{2}{|l|}{ Geräte } \\
\hline Waschgerät & Tecan \\
\hline Mikrotiterplatten-Lesegerät & Fluostar Optima (BMG Labtech) \\
\hline \multicolumn{2}{|l|}{ Verbrauchsmaterial } \\
\hline $\begin{array}{l}\text { Safe- Lock-Reaktionsgefäße }(0,5 \mathrm{ml} \text {, } \\
1,5 \mathrm{ml}, 2 \mathrm{ml})\end{array}$ & Eppendorf AG, Hamburg, Deutschland \\
\hline Mikrotiter-Platte & Microlon von Greiner, F-Boden \\
\hline \multicolumn{2}{|l|}{ Chemikalien } \\
\hline Substrat & TMB (Sigma) \\
\hline Stopplösung & Schwefelsäure (Sigma) \\
\hline Glycerin & Carl Roth GmbH + Co. KG, Karlsruhe, Deutschland \\
\hline \multicolumn{2}{|l|}{ Lösungen, Medien und Puffer } \\
\hline PBS $[1 X]$ & $100 \mathrm{ml} \mathrm{PBS}[10 \mathrm{X}]$, ad $900 \mathrm{ml} \mathrm{H} \mathrm{H} \mathrm{O}$ \\
\hline Waschpuffer & 1x PBS mit 0,01\% Tween \\
\hline Probenpuffer & Waschpuffer + 10\% Skim Milk + 5\% BSA \\
\hline Blockingpuffer & $\begin{array}{l}\text { anti-E. coli-Ak 1:1000 in Probenpuffer (für eine ganze Platte: } \\
20 \mu \mathrm{l} \text { Ak }+20 \mathrm{ml} \text { Probenpuffer) }\end{array}$ \\
\hline
\end{tabular}

\section{Seren}

48 Humanseren (anonymisiert)

OFA Dr. Gerhard Dobler, Institut für Mikrobiologie der Bundeswehr, München

15 Rinderseren (geimpfte Tiere),

Prof. Mohamed A. M. Shalaby, Universität Kairo

20 Schafseren (geimpfte Tiere)

Die Kavitäten von Mikrotiterplatten werden über Nacht mit aufgereinigtem RVFV-GnProtein beschichtet und unspezifische Bindungsstellen mit anti-E. coli-Antikörpern abgesättigt.

Die Beschichtung der Mikrotiter-Platte mit His-tagged-RVFV-Gn Protein in Verdünnung 1:50 in PBS (bei einer Ausgangskonzentration von 0,136 $\mu \mathrm{g} / \mu \mathrm{l}$ ) erfolgt jeweils mit $200 \mu \mathrm{l}$ pro Kavität. Anschließend folgt die Inkubation $1 \mathrm{~h}$ bei RT, danach über Nacht bei $4{ }^{\circ} \mathrm{C}$. Daraufhin wird die Mikrotiter-Platte 5x mit ca. $450 \mu$ l Waschpuffer pro Kavität gewaschen und unspezifische Bindungsstellen durch Inkubation für 1h bei RT mit $200 \mu$ l Blockingpuffer pro Kavität geblockt. 
Im ersten ELISA-Inkubationsschritt binden die nachzuweisenden Anti-RVFV-Gn-Antikörper aus positiven Tier- bzw. Patientenseren an die RVFV-Gn-Proteinschicht: Die Mikrotiterplatte wird 5x gewaschen, anschließend erfolgt die Inkubation in einem Doppelansatz (100 $\mu$ l pro Kavität) von 1:100 in Probenpuffer verdünnten Proben (Seren, Blank, Positiv-/Negativkontrolle) für $1 \mathrm{~h}$ bei RT.

Im zweiten ELISA-Inkubationsschritt werden die gebundenen Anti-RVFV-Gn-Antikörper mit den speziesabhängigen Fc-Abschnitt des ersten Antikörpers gebunden: Dazu wird der zweite Antikörper 5x gewaschen und mit HRP Konjugat 1:8000 in Probenpuffer verdünnt. Die Konjugation erfolgt bei Inkubation von $100 \mu \mathrm{l}$ pro Kavität für $1 \mathrm{~h}$ bei RT.

Im dritten ELISA-Inkubationsschritt erfolgt mit Hilfe des gebundenen SekundärantikörperHRP-Konjugats eine Farbreaktion. Die Absorption der gefärbten Lösung ist proportional zur Anti-RVFV-Gn-Antikörper-Konzentration im Probenserum: Die Mikrotiterplatte wird dazu abschließend 5x gewaschen und $100 \mu \mathrm{l}$ gebrauchsfertiges Substrat pro Kavität zeitgleich zugegeben. Die Inkubation beträgt $15 \mathrm{~min}$ bei RT im Dunkeln. Anschließend wird die Reaktion mit $100 \mu \mathrm{l}$ Schwefelsäure pro Kavität gestoppt und die Absorption innerhalb von 5 min mittels Microplate-Reader gemessen.

\subsubsection{Cut-off-Berechnung nach Frey}

Für die Auswertung der Ergebnisse von Immunoassays sind nur für wenige Virusproteine definierte Positiv-Standards verfügbar. Sind diese nicht vorhanden, was auch auf RVFVProteine zutrifft, wird typischerweise ein Endpunkttiter bestimmt. Dieser Titer ist definiert als Kehrwert der höchsten Analytverdünnung, die noch ein Signal hervorruft, das über dem sogenannten Cut-off-Wert liegt. Es gibt jedoch keine allgemein akzeptierte Regel, um den Cut-off-Wert zu bestimmen. Bei ELISAs wird hierzu oftmals der Mittelwert der Hintergrundabsorption bzw. der Absorption der Negativkontrollen gebildet und die dreifache Standardabweichung addiert. Teilweise ist der Cut-off lediglich ein reiner Erfahrungswert, dem keine reproduzierbare Methodik zugrunde liegt. Diese Verfahren liefern keine statistisch aussagefähigen Informationen bezüglich des Risikos der Übertitration oder falsch niedriger Titer. Daher wird in dieser Arbeit zur Bestimmung des 
Cut-off-Wertes die Methode nach Frey et al. (1998) verwendet. Hierbei erfolgt die Berechnung des Cut-off-Wertes durch Bestimmung der oberen Vorhersagegrenze für die Absorptionswerte negativer Seren mit Hilfe der Student-t-Verteilung. Hierzu wird für alle Seren, bei denen mittels IFT keine RVFV-Antikörper nachweisbar sind, der Absorptionswert $\left(x_{i}\right)$ im ELISA bestimmt und der Mittelwert $(\bar{X})$ gebildet. Der Cut-off berechnet sich daraus nach folgender Formel:

$$
\text { Cut-off }=\bar{X}+\mathrm{SD} \cdot f, \text { mit } f=t \sqrt{1+\frac{1}{n}} \text { und } \mathrm{SD}=\sqrt{\frac{\sum\left(x_{i}-\bar{X}\right)^{2}}{n-1}}
$$

wobei SD die Standardabweichung und $f$ ein Gewichtungsfaktor ist. Im Faktor $f$ ist mittels $t$ das Konfidenzintervall (1- $\alpha$ ) berücksichtigt, für das der Cut-off Wert berechnet wird. Dabei stellt $t$ das (1- $\alpha)$-Quantil der einseitigen t-Verteilung mit n-1 Freiheitsgraden dar, das z. B. aus statistischen Tabellen oder durch die Excel-Funktion T.INV zugänglich ist.

\subsection{Virologische Methoden}

\subsubsection{Anzucht von RVFV-Klon-13 in Zellkultur}

Tabelle 12: Materialien

\begin{tabular}{ll}
\hline Standardmaterialien & siehe Seite 20 \\
\hline $\begin{array}{l}\text { Zelllinien } \\
\text { Vero E6 }\end{array}$ & Epithelzellen aus der Niere der Äthiopischen Grünmeerkatze, \\
& ATCC, Manassas, USA \\
\hline Viren & Rift Valley Fever Virus, apathogenes RVFV-Isolat mit Deletion im \\
RVFV-Clone-13 & NSs-Gen (Lopez et al. 1995) \\
\hline $\begin{array}{l}\text { Lösungen, Medien und Puffer } \\
\text { NTE }\end{array}$ & $10 \mathrm{mM}$ Tris, pH 6,5, $1 \mathrm{mM} \mathrm{EDTA,} 100 \mathrm{mM} \mathrm{NaCl}$
\end{tabular}

Je $5 \cdot 10^{5}$ Vero-E6-Zellen werden in zwei $25-\mathrm{cm}^{2}$-Gewebekulturflaschen in $5 \mathrm{ml}$ Medium ausgesät und bis zum Erreichen einer ca. 50\%igen Konfluenz bei $37{ }^{\circ} \mathrm{C}$ inkubiert. Die Infektion erfolgt nach 4 Tagen. Dazu wird der Überstand aus den Gewebekulturflaschen verworfen und die Zellen mit $20 \mu$ l Virussuspension (RVFV-Klon-13) für 1 Stunde unter 5\% $\mathrm{CO}_{2}$ bei $37^{\circ} \mathrm{C}$ inkubiert. Auf Grundlage der ausgesäten Zellzahl wird die für die Infektion optimale MOI berechnet. Nach Ablauf der Inkubationszeit wird das Volumen mit $25 \mathrm{ml}$ 
Medium (DMEM) aufgefüllt und die Zellen bis zum Auftreten eines zytopathischen Effekts (CPE) über Nacht unter $5 \% \mathrm{CO}_{2}$ bei $37^{\circ} \mathrm{C}$ inkubiert. Die Ernte des Überstands mit abgelösten, infizierten Zellen erfolgt bei Erreichen des CPE, nach etwa 2 Tagen.

Zur Virusernte werden $27 \mathrm{ml}$ des geernteten Überstands für $7 \mathrm{~min}$ bei $1500 \mathrm{rpm}$ und $4{ }^{\circ} \mathrm{C}$ zentrifugiert, der Rest bei $-80{ }^{\circ} \mathrm{C}$ zur Lagerung tiefgefroren. Der Überstand der Zentrifugation wird abpipettiert, mit 1,48 ml $5 \mathrm{M} \mathrm{NaCl}+10,8 \mathrm{ml} 30 \%$ PEG 8000 in NTE gegeben und für 30 min bei $4{ }^{\circ} \mathrm{C}$ invertiert. Nun wird die Probe erneut für 60 min bei $6000 \mathrm{rpm}$ und $4{ }^{\circ} \mathrm{C}$ zentrifugiert, der Überstand verworfen und das gewonnene Pellet zur Lagerung bis zur folgenden RNA-Isolation (2.5.1) auf $-80^{\circ} \mathrm{C}$ tiefgefroren.

\subsection{Molekularbiologische Methoden}

\subsubsection{RNA-Isolierung aus Viruspartikeln}

Tabelle 13: Materialien

\begin{tabular}{ll}
\hline Standardmaterialien & siehe Seite 20 \\
\hline Geräte & \\
Spektralphotometer NanoDrop & PEQLAB Biotechnologie GmbH, Erlangen, Deutschland \\
\hline Chemikalien & \\
2-Propanol (Isopropanol) & Merck KGaA, Darmstadt, Deutschland \\
Chloroform & Merck KGaA, Darmstadt, Deutschland \\
DEPC-Wasser & Carl Roth GmbH \& CoKG, Karlsruhe, Deutschland \\
Ethanol abs. & Carl Roth GmbH \& CoKG, Karlsruhe, Deutschland \\
peqGOLD RNA-TriFast & PEQLAB Biotechnologie GmbH, Erlangen, Deutschland
\end{tabular}

Es wird nach der peqGOLD RNA-TriFast-Arbeitsanleitung von Peqlab gearbeitet. Die Methode basiert auf Flüssigphasen-Separation. Das Reagenz beinhaltet Guanidinisothiocyanat zur Lyse von Viren und Inaktivierung von RNAsen sowie Phenol, in dem sich Proteine und DNA Iösen. Nach Zugabe von Chloroform und anschließender Zentrifugation findet die Phasentrennung statt. Die Proteine befinden sich in der Phenolphase, DNA in der Interphase und RNA in der oberen, wässrigen Phase. Nun folgen die RNA-Präzipitation mittels Isopropanol und die abschließende Resuspendierung der RNA in Wasser. 
Das in (2.4.1) gewonnenen Pellet wird unter Zugabe von $2 \mathrm{ml}$ TriFast Lysepuffer für $5 \mathrm{~min}$ aufgetaut und per Vortex aufgeschüttelt, bis es sich vollständig gelöst hat. Nun wird 0,4 ml Chloroform zugegeben und für $10 \mathrm{~min}$ bei RT inkubiert. Abschließend wird $10 \mathrm{~min}$ bei $6000 \mathrm{rpm}$ und $4{ }^{\circ} \mathrm{C}$ zentrifugiert.

Es entstehen zwei makroskopisch sichtbare Phasen, diejenige mit klarer Flüssigkeit wird abgenommen und auf Eis gestellt. $4 \mu \mathrm{l}$ Glykogen $(35 \mu \mathrm{g} / \mu \mathrm{l})$ und $1 \mathrm{ml}$ Isopropanol werden zugegeben und für 15 min auf Eis inkubiert und darauffolgend für 20 min bei $6000 \mathrm{rpm}$ und $4{ }^{\circ} \mathrm{C}$ abzentrifugiert. Das Pellet wird 2x mit $1 \mathrm{ml}$ 75\% EtOH gewaschen und erneut für $20 \mathrm{~min}$ bei 6000 rpm abzentrifugiert. Das Pellet wird für 30 min trocknen gelassen, dann in $50 \mu l$ $\mathrm{dd}_{2} \mathrm{O}$ resuspendiert und die RNA Konzentration mittels eines Spektralphotometers gemessen (2.5.2). Die isolierte RNA wird bei $-80^{\circ} \mathrm{C}$ gelagert.

\subsubsection{Spektrometrische Konzentrationsmessung von RNA}

Tabelle 14: Materialien

\begin{tabular}{ll}
\hline Standardmaterialien & siehe Seite 20 \\
\hline Geräte & \\
$\begin{array}{l}\text { Spektralphotometer NanoDrop } \\
\text { PEQLAB Biotechnologie GmbH, Erlangen, } \\
\text { Deutschland }\end{array}$ \\
\hline
\end{tabular}

Chemikalien

ddHO ultrafiltiertes, deionisiertes Wasser

Die Konzentration wässeriger DNA- oder RNA-Lösungen kann direkt mittels Lichtabsorption in einem Spektralphotometer gemessen werden. Die Basen der Nukleinsäuren besitzen bei einer Messwellenlänge von $260 \mathrm{~nm}$ ihr Absorptionsmaximum. Aromatische Aminosäuren und Phenole absorbieren dagegen bei $280 \mathrm{~nm}$, so dass durch die Messung der Absorption (als Optische Dichte, OD) bei diesen Wellenlängen eine Abschätzung der Reinheit der Nukleinsäurelösung möglich ist. Nach der Eichung des Photometers auf den entsprechenden Probenpuffer werden zur Messung 1,5 $\mu$ l Probenvolumen eingesetzt. 


\subsubsection{Reverse Transkription}

Tabelle 15: Materialien

\begin{tabular}{|c|c|}
\hline Standardmaterialien & siehe Seite 20 \\
\hline \multicolumn{2}{|l|}{ Geräte } \\
\hline Thermocycler & Biometra $\mathrm{GmbH}$, Göttingen, Deutschland \\
\hline \multicolumn{2}{|l|}{ Verbrauchsmaterialien } \\
\hline PCR-Reaktionsgefäße (0,2ml) & $\begin{array}{l}\text { Greiner Bio-One GmbH, Frickenhausen, } \\
\text { Deutschland }\end{array}$ \\
\hline \multicolumn{2}{|l|}{ Chemikalien } \\
\hline \multicolumn{2}{|l|}{$\mathrm{ddH}_{2} \mathrm{O}$ ultrafiltiertes, deionisiertes Wasser } \\
\hline DEPC-Wasser & Carl Roth GmbH \& CoKG, Karlsruhe, Deutschland \\
\hline Dithiothreitol (DTT) & Invitrogen Corporation, Kalifornien, USA \\
\hline \multicolumn{2}{|l|}{ Enzyme, Nukleotide } \\
\hline Desoxyribonukleotidtriphosphate (dNTPs) 100 mM & Fermentas GmbH, St. Leon-Rot, Deutschland \\
\hline Random Hexamer Primer & $\begin{array}{l}\text { Amersham Biosciences Europe } \mathrm{GmbH} \text {, Freiburg, } \\
\text { Deutschland }\end{array}$ \\
\hline Superscript III & Invitrogen Corporation, Kalifornien, USA \\
\hline \multicolumn{2}{|l|}{ Puffer } \\
\hline 5X First-Strand Buffer & Invitrogen Corporation, Kalifornien, USA \\
\hline
\end{tabular}

Reverse Transkription beschreibt die Übersetzung eines RNA-Genoms in cDNA. Dazu ist das Enzym Reverse Transkriptase notwendig, eine RNA-abhängige DNA-Polymerase. Zunächst wird ein RNA-DNA-Hybridstrang gebildet, wobei die RNA in DNA geschrieben wird. Anschließend wird die RNA durch den Rnase-Anteil des Enzyms abgebaut und der DNAEinzelstrang zum DNA-Doppelstrang ergänzt. Durch den Einsatz des rekombinant hergestellten Enzyms Superscript III wird die RNA nicht abgebaut und kann so wiederholt abgelesen werden, die Herstellung eines DNA-Doppelstrangs unterbleibt. Unter Verwendung von randomisierten Primern wird die RNA komplett in einzelsträngige DNA übertragen.

Zur Durchführung einer Reverse Transkription werden an einer Sterilbank pro Probe zunächst $1 \mu \mathrm{l}$ Random Hexamer Primer (100 ng) mit $1 \mu \mathrm{l}$ dNTP und $11 \mu \mathrm{l}$ Bidest vermischt, dann $1 \mu$ RNA hinzugefügt und für 5 min bei $65^{\circ} \mathrm{C}$ inkubiert. Anschließend wird die Probe für 1 min auf Eis gestellt. Daraufhin werden $4 \mu$ First Strand Puffer, $1 \mu$ DTT (0,1 M) und $1 \mu \mathrm{l}$ Superscript III zugegeben, die Probe in einen Thermocycler überführt und das 
Inkubations-Programm gestartet $\left(5 \mathrm{~min} / 25^{\circ} \mathrm{C}, 60 \mathrm{~min} / 50{ }^{\circ} \mathrm{C}, 15 \mathrm{~min} / 70^{\circ} \mathrm{C}\right.$, Endtemperatur $\left.8^{\circ} \mathrm{C}\right)$. Die Lagerung der erzeugten cDNA erfolgt tiefgefroren bei $-20^{\circ} \mathrm{C}$.

\subsubsection{Touchdown PCR}

Tabelle 16: Materialien

\begin{tabular}{|c|c|}
\hline Standardmaterialien & siehe Seite 20 \\
\hline \multicolumn{2}{|l|}{ Geräte } \\
\hline PCR-Bank & G\&P Kunststofftechnik, Kassel, Deutschland \\
\hline Thermocycler & Biometra GmbH, Göttingen, Deutschland \\
\hline \multicolumn{2}{|l|}{ Verbrauchsmaterialien } \\
\hline PCR-Reaktionsgefäße $(0,2$ ml) & $\begin{array}{l}\text { Greiner Bio-One } \mathrm{GmbH} \text {, Frickenhausen, } \\
\text { Deutschland }\end{array}$ \\
\hline \multicolumn{2}{|l|}{ Chemikalien } \\
\hline Destilliertes Wasser für PCR & Invitrogen Corporation, Kalifornien, USA \\
\hline \multicolumn{2}{|l|}{ Enzyme, Nukleotide } \\
\hline Desoxyribonukleotidtriphosphate (dNTPs) 100 mM & Fermentas GmbH, St. Leon-Rot, Deutschland \\
\hline Taq-DNA-Polymerase & PRIME GmbH, Hamburg, Deutschland \\
\hline \multicolumn{2}{|l|}{ Puffer } \\
\hline PCR Puffer [10x] & PRIME GmbH, Hamburg, Deutschland \\
\hline
\end{tabular}

Durch die Polymerase-Ketten-Reaktion (Polymerase Chain Reaction, PCR) ist die Amplifizierung eines bestimmten DNA-Abschnitts (Templates) in vitro möglich. Dabei finden mehrere Zyklen von Denaturierung, Primerhybridisierung und Elongation mit Hilfe einer hitzestabilen DNA-Polymerase statt.

Das Aufschmelzen des DNA-Doppelstrangs (Denaturierung) in Einzelstränge erfolgt bei $95^{\circ} \mathrm{C}$, es folgt die spezifische, komplementäre Anlagerung der Oligonukleotide (Primer) an die DNA bei $58^{\circ} \mathrm{C}$ (Primerhybridisierung), anschließend werden die Einzelstränge mit neuen, freien Desoxyribonukleotidtriphosphaten (dNTPs) mit einer hitzestabilen DNAPolymerase bei $68^{\circ} \mathrm{C}$ verlängert (Elongation, Tabelle 17). Durch Wiederholung der drei Schritte der PCR wird das Ausgangsprodukt exponentiell vervielfältigt. Die hier verwendete, hitzestabile Taq-Polymerase aus dem Bakterium Thermus aquaticus besitzt keine Korrekturlesefähigkeit, stattdessen eine hohe Produktivität und Amplifikationsgeschwindigkeit. Weiterhin dient sie der Vorbereitung des PCR-Produkts auf die folgende 
Tabelle 17: Herstellung eines um die für die TA-Klonierung notwendigen A-Enden verlängerten, spezifischen PCR-Produktes mit Taq-Polymerase.

Zusammensetzung eines PCR-Ansatzes (49 $\mu \mathrm{l})$

$35 \mu$ l Bidest, $5 \mu \mathrm{l} \mathrm{MgCl}$, $5 \mu$ l 10x PCR-Puffer, $1 \mu \mathrm{l}$ dNTPs (10 mM), $1 \mu$ l Primer for $(10 \mu \mathrm{M}), 1 \mu \mathrm{l}$ Primer rev $(10 \mu \mathrm{M}), 1 \mu \mathrm{l}$ Taq-Polymerase und $1 \mu \mathrm{l}$ Template.

Template: RVFV Klon 13 cDNA, für Negativkontrolle durch Wasser ersetzen

Primerpaar: RVFV-GnS-for / RVFV-GnS-rev

\begin{tabular}{llll}
\hline \multicolumn{2}{c}{ Thermocycler-Profil: Touchdown } & \\
& Schritt & Temperatur $\left[{ }^{\circ} \mathrm{C}\right]$ & Zeit [s] /(Wiederholungen) \\
1 & Denaturierung & 95 & 120 \\
2 & Denaturierung & 95 & $30(10 \mathrm{x})$ \\
3 & Primer Annealing & 58 & $30(10 \mathrm{x})$ \\
4 & Elongation & 68 & $90(10 \mathrm{x})$ \\
5 & Denaturierung & 95 & $30(25 \mathrm{x})$ \\
6 & Annealing & 53 & $30(25 \mathrm{x})$ \\
7 & Elongation & 68 & $90(25 \mathrm{x})$ \\
8 & Finale Elongation & 68 & 300 \\
9 & & 10 & bis Entnahme
\end{tabular}

TA-Klonierung (2.5.6). Weitere Bestandteile der PCR sind dNTPs für die Anlagerung an den DNA-Strang und Magnesiumchlorid, das Einfluss auf die Primer-DNA-Bindungsstabilität hat und für die Polymerase spezifische Puffer.

Bei der Touchdown PCR ist das Thermocycler-Profil gegenüber der Standard-PCR abgewandelt, um die Amplifikatsmenge unter Erhalt hoher Spezifität zu steigern. Durch eine zunächst hohe Annealing-Temperatur nur knapp unterhalb der Denaturierungstemperatur ist die Bindung des Primers an das DNA-Template höchst spezifisch, allerdings typischerweise auch wenig effizient. Dies wird durch das Absenken der AnnealingTemperatur im nächsten Schritt kompensiert. Aufgrund des bereits im ersten Schritt erzeugten spezifischen Amplifikats ist die Bindung des Primers an ein korrektes Template nun statistisch bevorzugt, wodurch die übermäßige Amplifikation unspezifischer DNASequenzen vermieden wird. Bei der hier durchgeführten PCR wurde cDNA als Template verwendet, welche zuvor durch Reverse Transkription aus RNA hergestellt wurde. 


\subsubsection{Agarosegelelektrophorese und -extraktion}

Tabelle 18: Materialien

\begin{tabular}{|c|c|}
\hline Standardmaterialien & siehe Seite 20 \\
\hline \multicolumn{2}{|l|}{ Geräte } \\
\hline ChemiDoc XRS System & Bio Rad Laboratories GmbH, München, Deutschland \\
\hline Gel-Elektrophoresekammer (groß) & Invitrogen Corporation, Kalifornien, USA \\
\hline Mikrowellengerät & AFK Deutschland GmbH, Hamburg, Deutschland \\
\hline Heizblock (Thermomixer) & Eppendorf AG, Hamburg, Deutschland \\
\hline \multicolumn{2}{|l|}{ Verbrauchsartikel } \\
\hline \multicolumn{2}{|l|}{ Skalpell } \\
\hline Nitril-Handschuhe & GE Healthcare Europe NV, Brüssel, Belgien \\
\hline \multicolumn{2}{|l|}{ Chemikalien } \\
\hline Agarose & Biozym Scientific GmbH, Oldendorf, Deutschland \\
\hline Ethidiumbromid-Lösung $(10 \mathrm{mg} / \mathrm{ml})$ & Carl Roth GmbH \& Co KG, Karlsruhe, Deutschland \\
\hline \multicolumn{2}{|l|}{ Nukleotide, Standards } \\
\hline 6x Orange Loading Dye & Fermentas GmbH, St. Leon-Rot, Deutschland \\
\hline $\begin{array}{l}\text { DNA-Längenstandard } \\
\text { (100 bp, Ultra Low Range) }\end{array}$ & Fermentas GmbH, St. Leon-Rot, Deutschland \\
\hline \multicolumn{2}{|l|}{ Puffer, Lösungen, Medien } \\
\hline Agarosegel (0,8\%ig) & $100 \mathrm{ml} \mathrm{TAE}$, 0,83 g Agarose, $5 \mu \mathrm{l}$ Ethidiumbromid-Lösung \\
\hline Agarosegel (1\%ig) & $100 \mathrm{ml}$ TAE [1x], $1 \mathrm{~g}$ Agarose, 5 $\mu$ l Ethidiumbromid-Lösung \\
\hline Agarosegel (3\%ig) & $100 \mathrm{ml}$ TAE [1x], $3 \mathrm{~g}$ Agarose, $5 \mu \mathrm{l}$ Ethidiumbromid-Lösung \\
\hline TAE $[1 x]$ & $40 \mathrm{ml} \mathrm{TAE}[50 \mathrm{x}]$ add. $1969 \mathrm{ml} \mathrm{H} \mathrm{H}_{2}$ \\
\hline TAE $[50 x]$ & 242 g Tris: 57,1 ml Essigsäure, $100 \mathrm{ml} \mathrm{0,5} \mathrm{M}$ EDTA (pH 8,0) \\
\hline
\end{tabular}

\section{Reagenziensätze}

Zymoclean Gel DNA Recovery Kit Zymoclean Research Corporation, Orange, USA

Zur Bestimmung der Länge von Nukleinsäure-Strängen (DNA oder RNA) kommt die Agarosegelelektrophorese zum Einsatz. Agarosegele bestehen aus vernetzten Agarosepolymeren, deren Porengröße konzentrationsabhängig ist. Je konzentrierter das Gel, desto kleiner sind die Poren. Agarosegele sind mit einer Porengröße von ca. 100 nm großporiger als Acrylamidgele mit ca. $10 \mathrm{~nm}$. Die negativ geladenen Nukleinsäurestränge können in solch einem Gel durch Anlegen eines elektrischen Feldes ihrer Länge nach aufgetrennt und mit bekannten Strängen verglichen werden (2.2.3)

Zur Visualisierung der Nukleinsäuren wird dem Agarosegel Ethidiumbromid zugesetzt, ein Farbstoff, der mit den Basen der DNA interkaliert. Interkaliertes Ethidiumbromid 
fluoresziert unter UV-Bestrahlung im sichtbaren Spektrum (Emissionsmaximum 580$590 \mathrm{~nm}$ ) wodurch leuchtende Banden im Agarosegel entstehen. Die Menge der aufgetrennten DNA kann durch die Fluoreszenzintensität der entsprechenden Banden abgeschätzt werden. Für präparative Gele sollte die DNA möglichst kurz mit UV-Licht beleuchtet werden, um Schäden an der DNA zu vermeiden.

Zum Gießen des Agarosegels wird die Agarose mit TAE im Mikrowellengerät aufgekocht, bis alle Klümpchen verschwunden sind und anschließend bis auf ca. $60^{\circ} \mathrm{C}$ abkühlen gelassen. Währenddessen werden Mini-Gelkammern (100 x 70 × 0,5 mm) für kleine Gele aufgebaut, dann das Gel mit Ethidiumbromid versetzt und luftblasenfrei in den Gelträger gegossen. Nach 10 min hat das Gel seine Endfestigkeit erreicht. Nun wird die Elektrophoresekammer mit Gelträger, vorbereiteten Proben, Laddermarker und Laufpuffer gefüllt. Die Laufzeit beträgt $60 \mathrm{~min}$ bei $100 \mathrm{~V}$ über der Kammer angelegter Spannung. Anschließend wird das Gel auf einen UV-Transilluminator überführt und fotografiert.

Zur Gelextraktion werden 3 Taschen des Kamms zusammengeklebt und die Gelschale (125 x 80 x 7,5 mm für ein großes Gel) verwendet. $45 \mu \mathrm{l}$ des Amplifikats werden mit $9 \mu \mathrm{l} 6 \mathrm{x}$ Orange Dye versetzt und $50 \mu \mathrm{l}$ der resultierenden Lösung eingefüllt. Nach der elektrophoretischen Auftrennung wird mit einem Skalpell die Bande unter UV-Licht eng ausgeschnitten und mittels des Zymoclean-Gel-DANN-Recovery-Kits gereinigt:

Dazu wird das Gel mit der 3-fachen Menge ADB Puffer versetzt und bei $55^{\circ} \mathrm{C}$ für $10 \mathrm{~min}$ inkubiert, bis es sich gelöst hat. Anschließend wird es in eine Zymo-Spin-Säule transferiert. Die Zentrifugation erfolgt bei 10.000 g für 30 s, dann wird der Filter (Zymo-Spin) 2x mit 200 $\mu \mathrm{l}$ Wash-Puffer jeweils bei $10.000 \mathrm{~g}$ für $30 \mathrm{~s}$ gewaschen. Zur Eluation der DNA aus dem Filter werden $6 \mu \mathrm{l}$ Bidest hinzugefügt und abschließend bei $10.000 \mathrm{~g}$ für $60 \mathrm{~s}$ zentrifugiert. Die Lagerung der gereinigten DNA erfolgt bei $4{ }^{\circ} \mathrm{C}$. 


\subsubsection{TA-Klonierung: Ligation und Transformation}

Tabelle 19: Materialien

\begin{tabular}{|c|c|}
\hline Standardmaterialien & siehe Seite 20 \\
\hline \multicolumn{2}{|l|}{ Verbrauchsmaterial } \\
\hline \multicolumn{2}{|l|}{ LB-Amp-Platten } \\
\hline \multicolumn{2}{|l|}{ Puffer, Lösungen, Medien } \\
\hline One Shot INVaF & Invitrogen $\mathrm{GmbH}$, Karlsruhe, Deutschland \\
\hline X-Gal & $40 \mathrm{mg} / \mathrm{ml}$ in Dimethylformamid \\
\hline SOC-Medium & $\begin{array}{l}25 \mathrm{ml}: 0,05 \% \mathrm{NaCl}, 2 \% \text { Trypton, } 0,5 \% \text { Hefeextrakt, } \\
20 \mathrm{mM} \text { Glucose, } 2,5 \mathrm{mM} \mathrm{KCL} \text { und } 10 \mathrm{mM} \mathrm{MgCl}_{2} \text { ad } \\
25 \mathrm{ml} \text { mit } \mathrm{H}_{2} \mathrm{O} \text { bidest auffüllen }\end{array}$ \\
\hline \multicolumn{2}{|l|}{ Enzyme } \\
\hline T4-DNA-Ligase & Roche Diagnostics GmbH, Mannheim, Deutschland \\
\hline \multicolumn{2}{|l|}{ Plasmide } \\
\hline pCRII (4kb TA-Klonierungsvektor) & Invitrogen $\mathrm{GmbH}$, Karlsruhe, Deutschland \\
\hline \multicolumn{2}{|l|}{ Bakterienstämme } \\
\hline $\begin{array}{l}\text { INVaF' (Genotyp F' endA1 recA1 } \\
\text { hsd } 17 \text { ( } \mathrm{rk}-\text {-, mk+) supE44 thi-1 gyrA96 } \\
\text { relA1 } \phi 80 / a c Z \Delta \mathrm{M} 15 \Delta(\text { lacZYA- } \\
\arg \mathrm{F}) \mathrm{U} 169 \lambda-)\end{array}$ & Invitrogen $\mathrm{GmbH}$, Karlsruhe, Deutschland \\
\hline \multicolumn{2}{|l|}{ Reagenziensätze } \\
\hline Dual Promotor TA Cloning Kit & Invitrogen $\mathrm{GmbH}$, Karlsruhe, Deutschland \\
\hline One Shot INV $\alpha F^{\prime}$ Competent Cells & Invitrogen $\mathrm{GmbH}$, Karlsruhe, Deutschland \\
\hline
\end{tabular}

Die TA-Klonierung ist ein schnelles Klonierungsverfahren, das ohne den Einsatz von Restriktionsenzymen auskommt (Abbildung 6). Dabei wird das zu klonierende PCR-Produkt um ein einzelnes Desoxyadenosin-Nukleosid (A) am 3-Hydroxy-Ende (3') verlängert, typischerweise durch Einsatz einer Taq-Polymerase während der PCR. Ein derart vorbereitetes Insert kann daraufhin direkt in einen vorbereiteten, linearisierten Vektor (Abbildung 7) ligiert werden, an dessen 3'-Enden sich jeweils ein Desoxythymidin-Nukleosid (T) befindet (Abbildung 6). Während der Ligation mittels einer DNA-Ligase werden die 3'Enden mit den 5-Phosphat-Enden (5') der Nukleinsäurensegmente durch Ausbildung von Phosphodiesterbindungen verknüpft und der Plasmidring dabei geschlossen. 


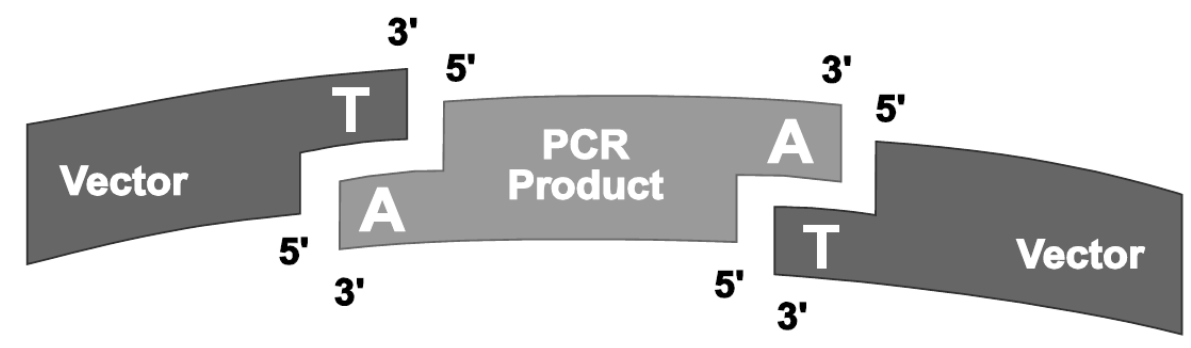

Abbildung 7: Prinzip der TA-Klonierung

Das verwendete Plasmid pCRII erlaubt eine schnelle Unterscheidung von transformierten, Kanamycin-resistenten E. coli Kolonien, die das gewünschte Plasmid mit Insert tragen, von solchen, die das unveränderte Plasmid aufgenommen haben über die Methode der BlauWeiß-Selektion. Grundlage hierfür ist das bakterielle Enzym $\beta$-Galaktosidase, welches aus zwei Untereinheiten ( $\alpha$ und $\omega$ ) besteht, die unabhängig voneinander exprimiert werden können und anschließend zum aktiven Enzym assoziieren. Dieses kann das artifizielle Substrat X-Gal (5-Brom-4-chlor-3-indoxyl- $\beta$-D-galactopyranosid) in Galaktose und 5-Brom4-chlor-indoxyl spalten. Letzteres oxidiert spontan zu 5,5'-Dibrom-4,4'-dichlor-indigo, welches eine tiefblaue Farbe besitzt.

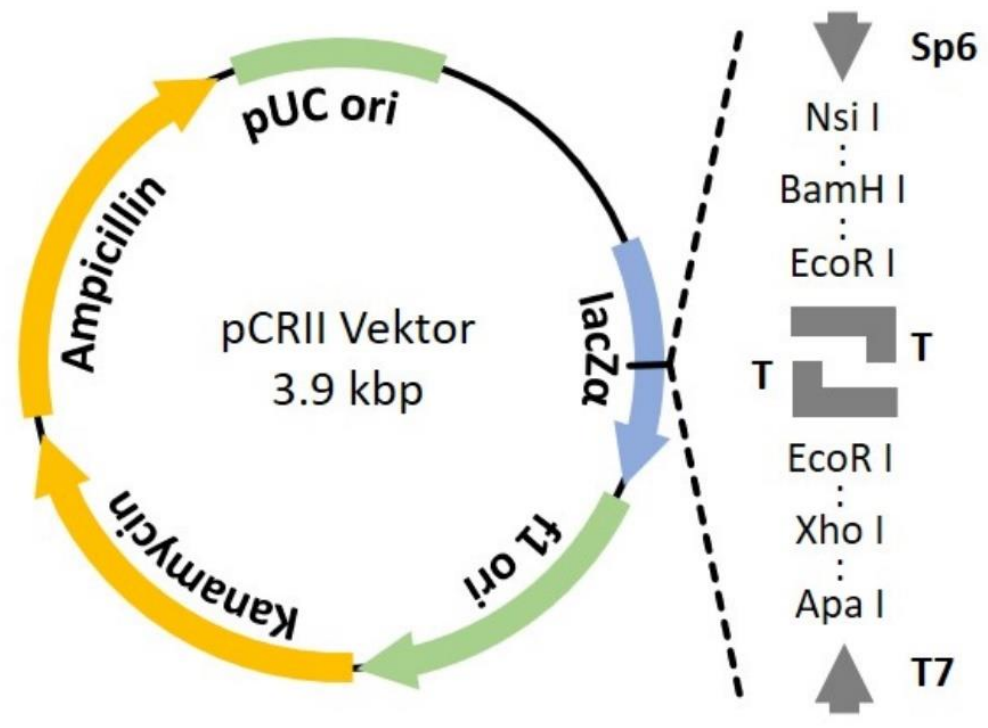

Abbildung 6: TA-Klonierungsplasmid pCRII.

Die genetische Information für die $\alpha$-Untereinheit (lacZ $\alpha$ ) der $\beta$-Galaktosidase befindet sich auf dem Plasmid pCRII, die genetische Information für die $\omega$-Untereinheit ist Teil des 
Genoms der zu transformierenden Bakterien. Die TA-Klonierungsstelle des Plasmids pCRII befindet sich innerhalb des lacZ $\alpha$ Gens. Wird hier cDNA eingefügt, wird der Leserahmen der $\alpha$-Untereinheit zerstört, d. h. nach Transformation kann in den Bakterien keine $\alpha$ Untereinheit und somit keine funktionelle $\beta$-Galaktosidase gebildet werden. Solche Bakterienkolonien erscheinen auf Selektionsagar, der das Selektionsmedium Kanamycin und das chromogene Substrat X-Gal enthält, weiß. Bakterien, die dagegen das unveränderte Plasmid pCRII aufgenommen haben, können funktionelle $\alpha$-Untereinheiten exprimieren, die dann mit den $\omega$-Untereinheiten zur enzymatisch aktiven $\beta$-Galaktosidase assoziieren (sog. Transkomplementation). Solche Bakterienkolonien erscheinen auf dem Selektionsagar blau und können somit leicht von den gewünschten weißen Kolonien unterschieden werden.

Nach Ligation der Insert-DNA in die linearisierte Vektor-DNA erfolgt die Transformation des Ligationsproduktes in chemisch kompetente E. coli-Zellen. Durch einen Hitzeschock werden die Bakterienzellen zur Aufnahme des Plasmids gebracht. Zuvor wird die Zellmembran mit Calciumchlorid behandelt, wodurch sich die abstoßenden Kräfte der DNA und der Bakterienzellmembran verringern. Die so entstehenden Poren in der Membran ermöglichen die Aufnahme der DNA innerhalb weniger Minuten.

Aufgrund der Antibiotikaresistenz und der Färbung (Blau-Weiß-Selektion) werden die Transformanten selektiert und die Plasmide durch eine Plasmid-DNA-Minipräparation isoliert. Abschließend werden die rekombinanten Plasmide über einen analytischen Restriktionsverdau identifiziert.

\subsubsection{Durchführung der Ligation}

Zur Ligation werden $3 \mu$ frisch gereinigtes PCR-Produkt, $1 \mu \mathrm{l}$ 10x Ligationspuffer, $2 \mu \mathrm{l}$ pCRII Vektor, $3 \mu$ l Bidest und $1 \mu$ I T4 DNA-Ligase gemischt und bei $14{ }^{\circ} \mathrm{C}$ über Nacht inkubiert.

\subsubsection{Durchführung der Transformation}

Zur Transformation werden kompetente Bakterien (INV $\left.\alpha F^{\prime}\right)$ etwa 10 min auf Eis aufgetaut und SOC-Medium auf RT gebracht. $2 \mu$ l Ligationsansatz werden zur Bakteriensuspension 
pipettiert, vorsichtig gemischt und 30 min auf Eis inkubiert. Der Hitzeschock erfolgt bei $42{ }^{\circ} \mathrm{C}$ für $30 \mathrm{~s}$, woraufhin $250 \mu \mathrm{l} \mathrm{SOC-Medium} \mathrm{zugegeben} \mathrm{werden} \mathrm{und} \mathrm{die} \mathrm{Flasche} \mathrm{für} 1 \mathrm{~h}$ bei $37^{\circ} \mathrm{C}$ und 300 rpm leicht geschüttelt wird. Währenddessen werden 2 LB-Amp-Platten vorbereitet: Um ein Blau-Weiß-Screening durchführen zu können, wird je Platte $40 \mu \mathrm{l}$ X-Gal Lösung ausgestrichen und über Nacht bei $37^{\circ} \mathrm{C}$ inkubiert.

\subsubsection{Auswertung der gewonnenen Klone}

Die gewachsenen Klonkolonien werden nach Anzahl und Farbe differenziert. Alle weißen Kolonien enthalten das Insert, die blauen nicht. 10 Klone werden gepickt und überprüft, ob sie das Plasmid enthalten. Dazu werden die einzelnen Klone in $4 \mathrm{ml} \mathrm{LB}$-Amp-Medium $37^{\circ} \mathrm{C}$ über Nacht auf dem Schüttelinkubator kultiviert. Gleichzeitig wird eine Referenzplatte angelegt.

\subsubsection{Isolation der Plasmid-DNA aus Bakterien}

Tabelle 20: Materialien

\begin{tabular}{ll}
\hline Standardmaterialien & siehe Seite 20 \\
\hline Reagenziensätze & \\
peq GOLD Plasmid Miniprep Kit I & peQlab Biotechnologie GmbH, Erlangen, Deutschland \\
Zymoclean Gel DNA Recovery Kit & Zymoclean Research Corporation, Orange, USA
\end{tabular}

Die in einer Transformation erzeugten Klone werden mittels einer Plasmid-Minipräparation und anschließendem Restriktionsverdau im Hinblick auf die Länge der enthaltenen PlasmidDNA untersucht. Durch Alkalibehandlung werden dabei sowohl chromosomale als auch Plasmid-DNA zunächst denaturiert und ausgefällt. Im daraufhin eingesetzten Hochsalzpuffer renaturiert ausschließlich Plasmid-DNA und geht wieder in Lösung, wonach sie von chromosomaler DNA, RNA und Proteinen per Zentrifugation getrennt werden kann. Die Plasmid-DNA aus dem Überstand wird gewaschen, eluiert und der DNA-Gehalt an einem Spektralphotometer gemessen.

Die Minipräparation von Plasmid-DNA mit peqGOLD Plasmid Miniprep Kit I erfolgt nach Angaben des Herstellers. 
Zur Anzucht der Bakterien wird die Übernachtkultur angeimpft, es folgen die alkalische Lyse der Bakterien und die Neutralisierung des Lysats. Die Bindung der DNA an die Silikamembran erfolgt durch Beladen der HiBind-DNA-Säule. Nach Waschen und Zentrifugation der Säule erfolgt zur Entfernung zellulärer Bestandteile und anderer Kontaminationen mit speziellen Puffern. Anschließend wird die Säule trocken zentrifugiert und die Elution der DNA erfolgt mit Bidest. Dann folgt die Messung des DNA-Gehalts am Spektralphotometer und die Lagerung der Proben bei $4{ }^{\circ} \mathrm{C}$.

\subsubsection{Restriktionsverdau von Plasmid-DNA}

Tabelle 21: Materialien

\begin{tabular}{ll}
\hline Standardmaterialien & siehe Seite 20 \\
\hline Enzyme & \\
FastDigest BamHI & Fermentas $\mathrm{GmbH}$, Leon-Rot, Deutschland \\
FastDigest Ndel & Fermentas $\mathrm{GmbH}$, Leon-Rot, Deutschland \\
PowerScript DNA Polymerase & PAN-Biotech $\mathrm{GmbH}$, Aidenbach, Deutschland
\end{tabular}

Zur Untersuchung des Restriktionsmusters eines rekombinanten Plasmids werden Restriktionsendonukleasen eingesetzt. Diese aus verschiedenen Bakterienstämmen synthetisierten Enzyme schneiden die Phosphodiesterbindungen der DNA an bekannten, spezifischen Stellen, woraus aus der ringförmigen Plasmid-DNA eine linearisierte Form entsteht. Die Aktivität und Spezifität der Enzyme werden durch pH-Wert, Temperatur, Salzkonzentration und den Gehalt an Kationen (vor allem $\mathrm{Mg}^{2+}$ ) beeinflusst. Die Länge der DNA-Fragmente, die durch den Restriktionsverdau entstehen, wird durch Gelelektrophorese bestimmt.

Der Ansatz eines typischen analytischen Doppelverdaus von rekombinanten Plasmiden setzt sich wie folgt zusammen: $1 \mu$ Plasmid-Minipräparations-DNA, $1 \mu \mathrm{l}$ 10x FD-Puffer, $1 \mu \mathrm{l}$

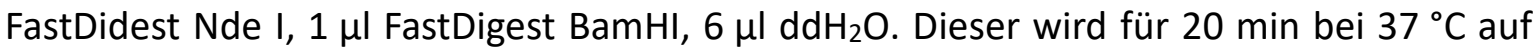
einem Thermoblock inkubiert. Abschließend werden zu $10 \mu \mathrm{l}$ Restriktionsansatz $2 \mu \mathrm{l} 6 \mathrm{x}$ Auftragungspuffer zugegeben und $10 \mu \mathrm{l}$ davon in einem analytischen Agarosegel elektrophoretisch aufgetrennt (2.5.5). 


\subsubsection{Sequenzierung}

Als DNA-Sequenzierung wird die Bestimmung der Nukleotidabfolge in einem DNA-Molekül bezeichnet. Dies erfolgt nach dem Prinzip der Kettenabbruchmethode nach Sanger (Sanger et al. 1977), wobei fluoreszenzmarkierte Didesoxynukleotide verwendet werden. Diese Technik nutzt die Eigenschaft der DNA, aus einem Doppelstrang zu bestehen, der in zwei Einzelstränge aufgetrennt werden kann, woraufhin sich mit Hilfe von Primer und DNAPolymerase die komplementären Basen anlagern.

Nach Reinigung der Plasmid-DNA mittels pegGOLD-Plasmid-Miniprep-Kit-I erfolgt die Kontroll-Sequenzierung durch ein externes Labor (SeqLab, Göttingen). Dazu wird ein Sequenzierungsansatz ( Tabelle 22) verschickt, der die verwendeten Primer miteinschließt.

Tabelle 22: Sequenzierungsansatz (7 $\mu \mathrm{l})$

\begin{tabular}{ll}
\hline $1,7 \mu \mathrm{l}$ & Template DNA (ca. $600 \mathrm{ng})$ \\
$2,0 \mu \mathrm{l}$ & Primer $(10 \mathrm{pmol} / \mu \mathrm{l})$ \\
$3,3 \mu \mathrm{l}$ & $\mathrm{ddH}_{2} \mathrm{O}$
\end{tabular}

\subsection{Immunfluoreszenztest als Referenzmethode}

Ein Immunfluoreszenztest (IFT) ist ein einfach zu handhabendes Verfahren zum Nachweis von Antikörpern, das die am häufigsten angewendete, standardisierte Methode zur Sicherung einer klinischen Verdachtsdiagnose darstellt. Dabei wird eine Probe künstlich infizierter Zellen mit dem zu testenden Serum inkubiert, so dass alle antigenspezifischen, im Serum vorhandenen Antikörper an infizierte Zellen binden. In einem zweiten Schritt werden gebundene Antikörper nun mit einem sekundären Antikörper, der gegen die Serumspezies gerichtet und mit einem Fluoreszenzmarker versehen ist, nachgewiesen. 
Die Intensität der Fluoreszenz ist dabei das Kriterium für die Bewertung des Serums als positiv oder negativ. Die Auswertung erfolgt unter dem Mikroskop und unterliegt der Subjektivität des Betrachters. Mit einem gewissen Maß an Übung ist die Klassifikation eines typischen Fluoreszenzbildes (Abbildung 8) jedoch ausreichend sicher und reproduzierbar. Im Gegensatz zum ELISA ist der IFT ein Verfahren, das meistens nur qualitative Ergebnisse liefert. Quantitative Daten sind nur mit großem Aufwand durch das Auszählen positiver Zellen zu erheben, was fehleranfällig ist.

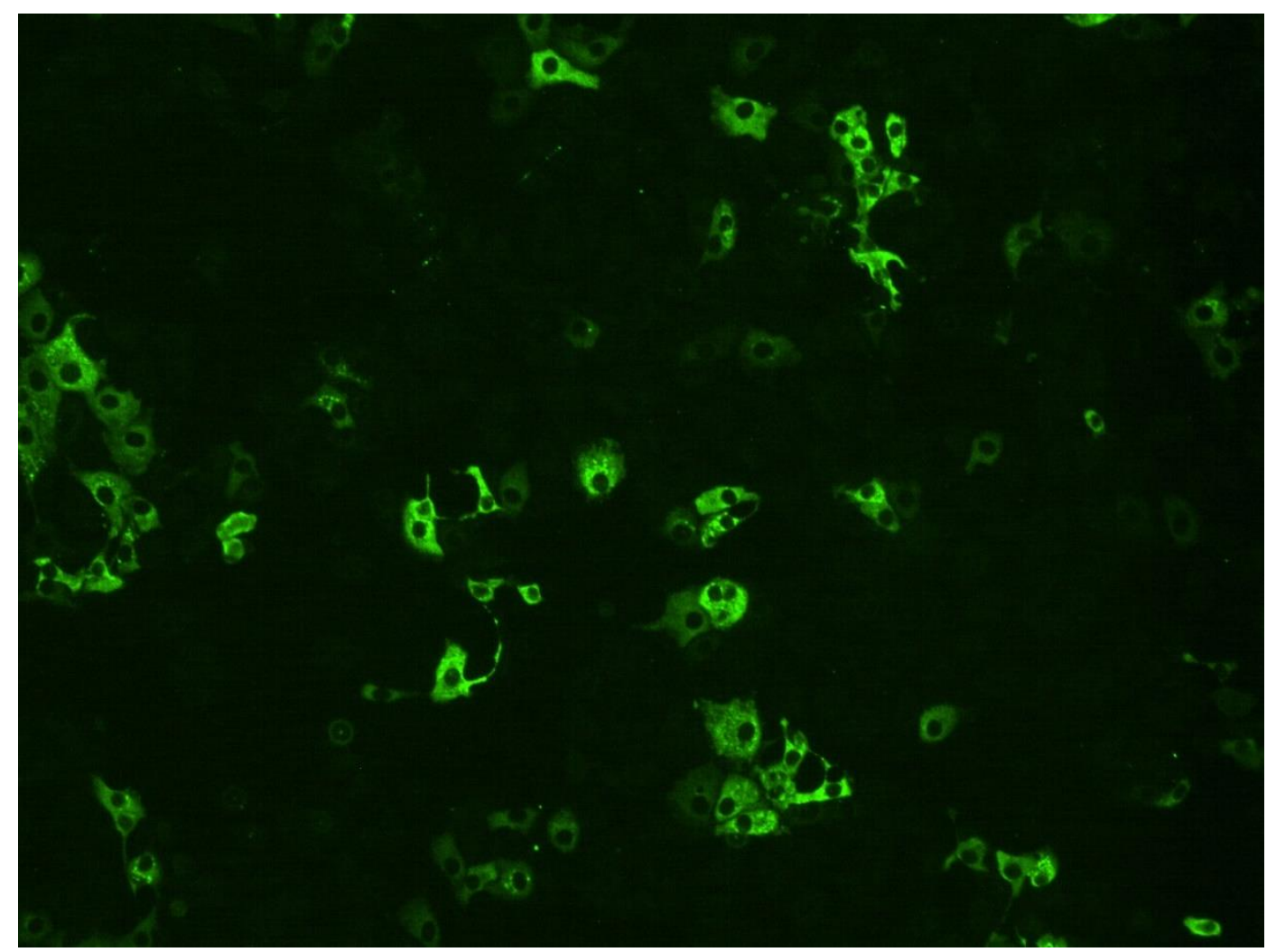

Abbildung 8: Das Immunfluoreszenzbild von mit RVFV-Antikörper-positivem Humanserum behandelten fixierten Testzellen zeigt die typische, starke zytosolische Färbung. 


\section{Ergebnisse}

\subsection{Etablierung des speziesunabhängigen, nichtkompetitiven ELISAs zur Detektion von RVFV-Nukleoprotein-Antikörpern}

Zur Etablierung eines speziesunabhängigen ELISAs zur Detektion von RVFV-NukleoproteinAntikörpern mit verbesserter Spezifität soll ein enzymmarkiertes Antigen anstatt eines enzymmarkierten Antikörpers eingesetzt werden. Dazu wird rekombinantes RVFV-NProtein benötigt, das zum einen auf der ELISA-Mikrotiterplatte als Antigencoating aufgebracht wird und zum anderen als HRP-Konjugat für die speziesunabhängige Detektion zum Einsatz kommt (3.1.3).

\subsubsection{Expression und Aufreinigung des RVFV-Nukleoproteins}

Zur Herstellung des RVFV-N-Proteins wurde auf einen bei $-80^{\circ} \mathrm{C}$ tiefgefrorenen Stock an genveränderten Darmbakterien der Gattung Escherichia coli (E. coli) zurückgegriffen, die das künstliche Plasmid pQE9-RVFV-N enthalten. Dabei handelt es sich um ein Plasmid mit induzierbarem Promoter, auf dem die Sequenz des um ein N-terminales His-Tag ergänzten $\mathrm{N}$-Proteins kodiert ist (Abbildung 9).

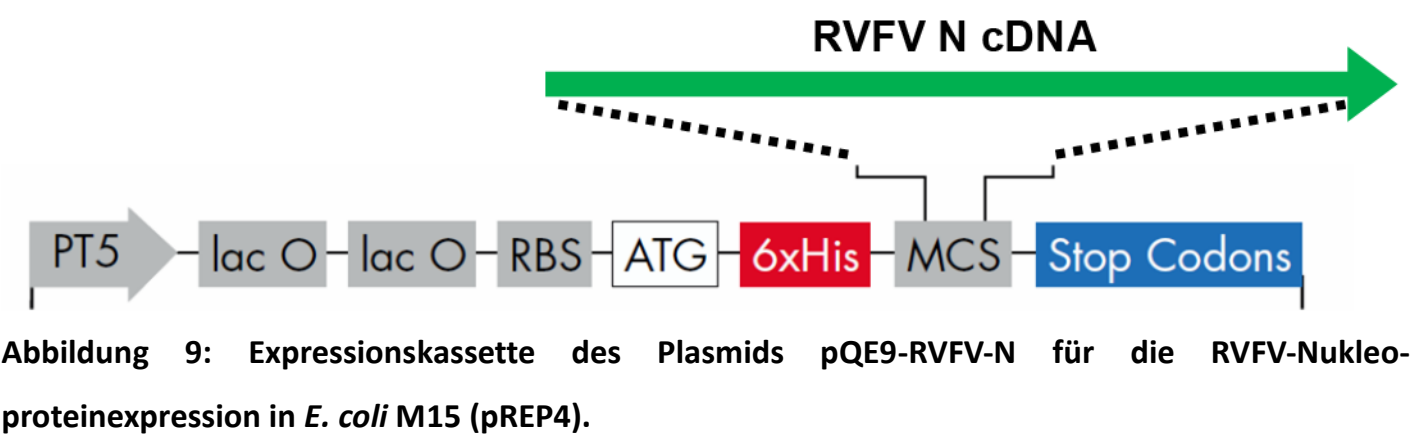

Nach Auftauen und Vermehren eines Teils dieses Stocks wurde die Proteinexpression mittels IPTG-Induktion initiiert (2.2.1.1). Nach exponentiellem Wachstum wurden die Bakterien geerntet, lysiert und zentrifugiert, wonach sich das N-Protein frei im Überstand befand. Mittels Affinitätschromatographie (Ni-NTA) wurden die gewünschten Proteine von sonstigen zellulären Proteinen, anderen Biomolekülen und unspezifischen Stoffen getrennt, 


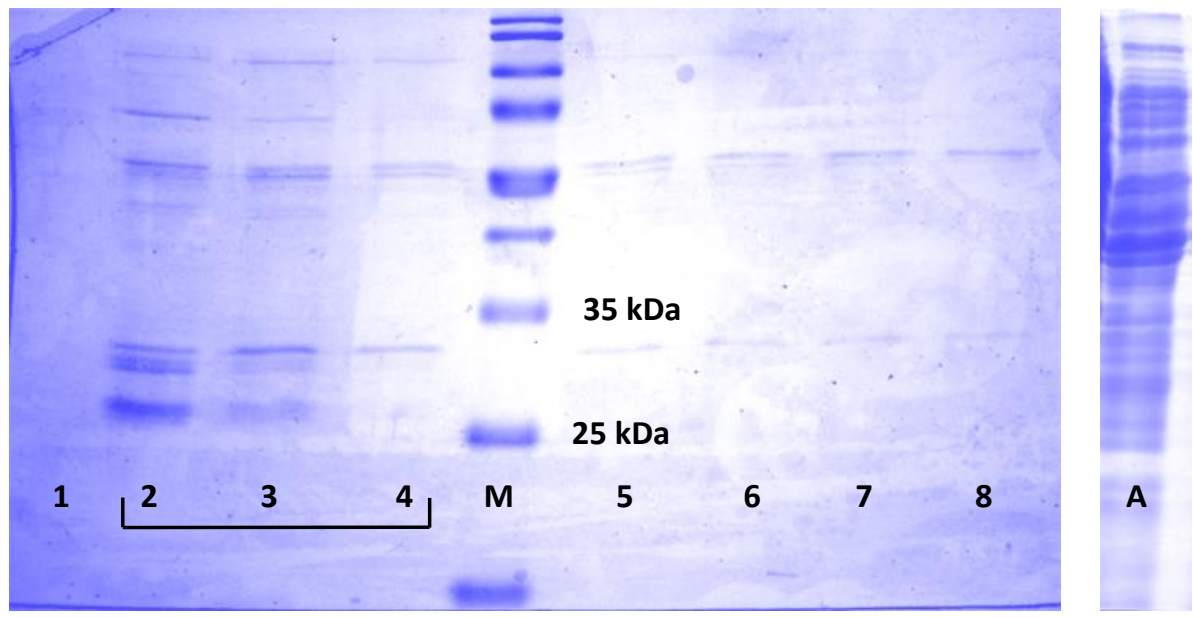

Abbildung 10: SDS-Gel zur Proteinkonzentrationsbestimmung mit Coomassie-Blau gefärbt. Es wurden acht Fraktionen auf das SDS-Gel aufgetragen (1-8). RVFV-N Monomere sind bei 25 kDa, RVFV-N-Multimere ab 35 kDa zu sehen. M: Molekulargewichtsmarker (10-170 kDa), Fraktionen 2-4 sind die gepoolten Fraktionen mit der höchsten Proteinkonzentration. A: Ausgangsmaterial, E. coli Lysat.

angereichert und anschließend per SDS-PAGE (Abbildung 10) und Western Blot (Abbildung 11) analysiert $(2.2 .3,2.2 .4)$. Zur Identifikation der gesuchten RVFV-NMonomere mit einem Molekulargewicht von 25 kDa wurde ein Molekulargewichtsmarker verwendet, der als Referenz für Moleküle im Bereich von 10-170 kDa dient. Bei drei von acht untersuchten Eluatfraktionen (Abbildung 10, Fraktionen 2-4) waren Banden an der richtigen Position zu erkennen. RVFV-N Multimere sind entsprechend größere Moleküle (oberhalb $35 \mathrm{kDa}$ ), die langsamer durch das Separationsgel wandern und im oberen Bereich des Gels zu finden sind (Abbildung 10). Durch den Nachweis mit Anti-His-tag-Antikörpern im Western Blot konnten die RVFV-N Monomere schließlich bestätigt werden (Abbildung 11).

\subsubsection{Konjugation des RVFV-Nukleoproteins mit HRP}

Der nächste Schritt zu einem funktionalen N-ELISA ist die Kopplung des Enzyms HRP an das RVFV-Nukleoprotein (2.1.8), um die Detektion von RVFV-Nukleoproteinantikörpern per Farbstoffreaktion zu ermöglichen. Dazu wurde der RVFV-N-Proteinlösung lyophilisierte Peroxidase, Cyanoborohydrid und ein Quenching-Puffer zugegeben. Nach der Inkubation 
des Konjugats wurde die Protein-Enzymlösung erneut mittels Ni-Affinitätschromatographie gereinigt, um sie von nicht gebundenem HRP zu befreien.

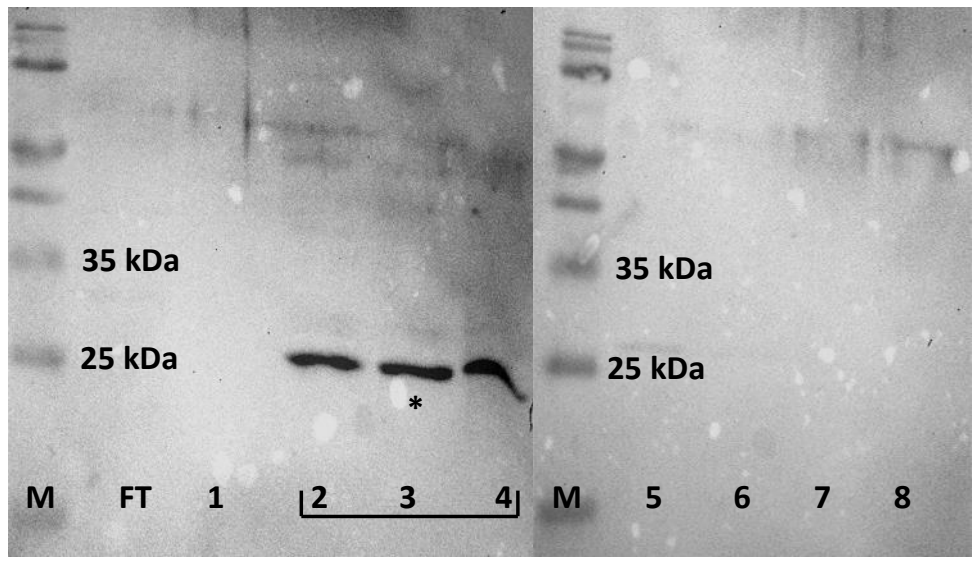

Abbildung 11: Western Blot des exprimierten RVFV-N-Proteins. Nachweis der His-RVFV-NBanden (*) mittels Anti-His-tag-Antikörpern. M: Molekulargewichtsmarker (10-170 kDa), FT: Flow-Through nach beladen der Säule, Fraktionen 1-8, mit gepoolten Fraktionen 2-4.

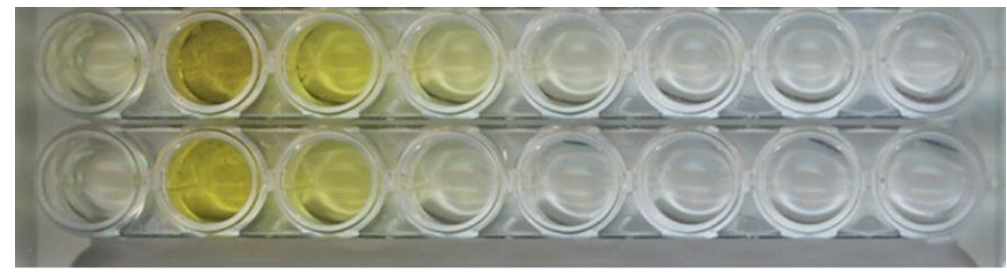

\section{$\begin{array}{llllllll}1 & 2 & 3 & 4 & 5 & 6 & 7 & 8\end{array}$}

Abbildung 12: HRP gekoppelter RVFV-Nukleoproteine. Es wurden die vier Fraktionen (2-

5, aus acht) mit der höchsten HRP-Aktivität vereinigt.

Nach der Konjugation des RVFV-Nukleoproteins mit HRP ließ sich das gekoppelte Enzym per Western Blot zunächst nicht nachweisen, woraufhin die Messung der HRP-Aktivität als alternatives Verfahren zum Einsatz kam. Dazu wurde jedes Eluat in PBS verdünnt, jeweils Substrat zugegeben und die einsetzende Farbreaktion anschließend mit Schwefelsäure gestoppt. Der Grad der Färbung als Maß für die Enzymaktivität wurde mittels eines Spektralphotometers gemessen. Die vier Fraktionen mit der höchsten Aktivität (Abbildung 12) wurden vereinigt, um ein Konjugat mit hoher Enzymaktivität zu erhalten. Durch Dialyse wurde die Pufferlösung durch PBS ausgetauscht und schließlich die Proteinkonzentration mittels BCA bestimmt. Der gemessene Wert betrug $200 \mu \mathrm{g} / \mathrm{ml}$. 


\subsubsection{Durchführung des ELISAs}

A.

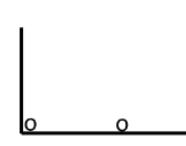

- RVFV-N Protein

入 anti-RVFV-N Antikörper aus dem Serum

B.

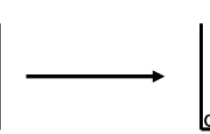

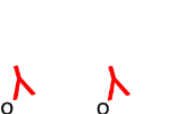

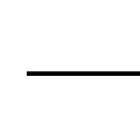

C.

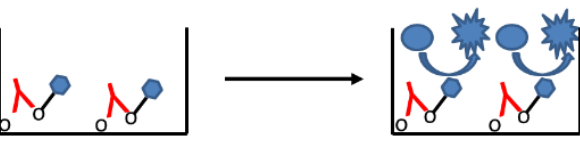

$\delta$ HRP-konjugiertes RVFV-N Protein

Substrat (farblos)

Substrat nach Umsetzung durch HRP (farbig)

Abbildung 13: Aufbau des neuentwickelten, speziesunabhängigen N-ELISAs.

Das Protokoll zur Durchführung des N-ELISAs ist in Abbildung 13 schematisch dargestellt. Zunächst werden Mikrotiterplatten mit RVFV-N-Proteinen als Antigen beschichtet (A). Nach Absättigung der unspezifischen Bindungsstellen binden spezifische Anti-RVFV-N Antikörper mit nur einem Arm an das N-Protein (B), was durch die niedrig eingestellte Konzentration der Antigenbeschichtung erreicht wird. Das RVFV-N-HRP-Konjugat bindet an den zweiten Arm des nachzuweisenden Antikörpers (C). Der Gebrauch des konjugierten Antigens eliminiert dabei den üblichen zweiten, HRP konjugierten, speziesabhängigen Antikörper, der gegen den Fc-Bereich des ersten Antikörpers gerichtet wäre. Durch Substratzugabe kommt es bei positivem Serum zum Farbumschlag (D), wobei die Absorption proportional zur Konzentration des Antikörpers ist.

\subsection{Vergleich mit anderen Nachweismethoden}

Zur Bewertung des in dieser Arbeit entwickelten N-ELISAs wurde er mit bereits verfügbaren ELISAs verglichen: Ein speziesabhängiger Sandwich-ELISA (s-ELISA) zum Test von Menschund Nutztierseren, der bereits zuvor in der Abteilung Virologie, UMG, entwickelt wurde, sowie der einzige kommerziell erhältliche RVFV-ELISA (ID Screen RVF, IDvet, im Folgenden bezeichnet als k-ELISA). Dabei handelt es sich um einen speziesunabhängigen, kompetitiven ELISA, dessen Zulassung aber auf Nutztierseren beschränkt ist und der somit nicht zum Test von Humanseren für diagnostische Zwecke eingesetzt werden darf.

Als Referenzverfahren zur Detektion von RVFV-Antikörpern wurde ein IFT (Euroimmun) herangezogen und alle Testseren in einer Verdünnung von 1:10 anhand ihres 
Fluoreszenzbildes beurteilt. Alle in dieser Arbeit aufgeführten Werte für Sensitivität und Spezifität der verwendeten Nachweisverfahren wurden gemäß der Definition dieser Größen in Abschnitt 1.3.2 berechnet. Die Ergebnisse des IFT dienten dabei als Wahr-positivbzw. Wahr-negativ-Referenz.

\subsubsection{Anpassung eines kommerziell verfügbaren RVFV-IFT als Referenzmethode}

Der in dieser Arbeit verwendete, kommerziell verfügbare RVFV-IFT (Euroimmun) ist nur für Tests mit Humanseren geeignet. Er wurde daher für die Detektion von Antikörpern aus Schaf- und Rinderseren durch Verwendung der entsprechenden FITC-markierten, speziesspezifischen Sekundärantikörper angepasst. Auf diese Weise führten Positivseren aller getesteten Spezies zu einem charakteristischen Fluoreszenzbild und hoben sich deutlich von Negativseren ab, bei denen lediglich eine schwache, unspezifische Hintergrundfärbung auftrat. Die korrekte Zuordnung aller Seren war somit mit hoher Sicherheit gegeben (Abbildung 8).

\subsubsection{Ergebnisse der Serodiagnostik}

Die Leistungsfähigkeit des N-ELISAs bei der Klassifikation von Humanseren wurde anhand einer Gruppe von 127 anonymisierten Seren aus Tansania (Heinrich et al. 2012) im Vergleich zum s-ELISA ermittelt (Abbildung 14).

Die Lagerung und Anonymisierung der Proben erfolgte dabei durch die Projektpartner. Für den experimentellen Teil dieser Arbeit wurden vom Institut für Mikrobiologie der Bundeswehr Aliquots der anonymisierten Seren (durchnummeriert) zur Verfügung gestellt, die ausschließlich zum Testen auf RVFV-Antikörper mittels ELISA bestimmt waren.

Zur Berechnung des Cut-off Werts für ein Konfidenzniveau von 99\% $(\alpha=0,01)$ wurden $n=73$ IFT-negative Seren herangezogen. Es ergab sich für die Absorption der negativen Seren ein durchschnittlicher Mittelwert $(\bar{X})$ von 0,026 mit einer Standardabweichung (SD) von 0,037. Nach der Methode von Frey (2.3.1) ergab sich mit $t(0,99 ; n-1)=2,379$ ein Cut-off von 0,115. 
Damit galten Humanseren mit gemessenen optischen Dichten bzw. Extinktionswerten von über 0,115 als positiv, darunter oder gleich als negativ.

Beide Tests erreichten bei einer Probenverdünnung von 1:100 eine Sensitivität von 87\%. In Bezug auf seine Spezifität schneidet der N-ELISA mit 99\% gegenüber dem s-ELISA mit 90\% wesentlich besser ab, da er die Zahl der falsch-positiven Ergebnisse um zwei Drittel reduziert. Im direkten Vergleich weichen die Einzelergebnisse der beiden ELISAs in 10 Fällen voneinander ab, wobei es sich fast ausschließlich um falsch-positive Ergebnisse des s-ELISA handelt.

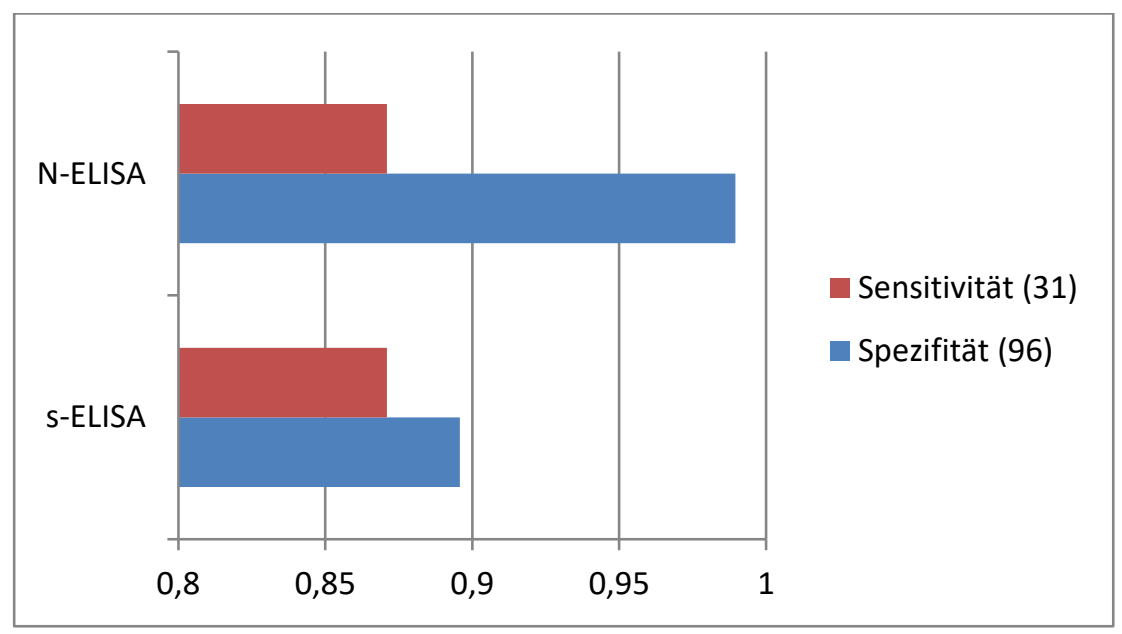

Abbildung 14: Vergleich des N-ELISAs mit einem zuvor in der Abteilung Virologie, UMG, entwickelten, speziesabhängigen Sandwich-ELISA (s-ELISA) anhand von Humanseren. In Klammern ist die Anzahl an Seren angegeben, die in die Berechnung von Sensitivität und Spezifität eingeflossen sind.

Die Leistungsfähigkeit des N-ELISAs in Bezug auf Nutztiere wurde im Vergleich zum kommerziellen k-ELISA anhand von 71 Rinderseren ermittelt, die 2004 während einer Feldstudie in Ägypten zusammengetragen und seitdem fortwährend bei $4{ }^{\circ} \mathrm{C}$ gelagert wurden. Zusätzlich wurde auf Daten einer externen Querschnittsuntersuchung zurückgegriffen, die mittels eines indirekten ELISAs (i-ELISA) erhoben wurden (Abbildung 15). Die genannten Seren und Daten wurden freundlicherweise zur Verfügung gestellt von Dr. A. Said, Institut für Virologie, FU Berlin. 
Zur Bestimmung des Cut-off Wertes für ein Konfidenzniveau von 99\% $(\alpha=0,01)$ standen n=48 IFT-negative Seren zur Verfügung. Es ergab sich für die Absorption der negativen Seren ein durchschnittlicher Mittelwert $(\bar{X})$ von 0,075 mit einer Standardabweichung (SD) von 0,038 . Nach der Methode von Frey (2.3.1) ergab sich mit $t(0,99 ; n-1)=2,408$ ein Cut-off-Wert von 0,167. Damit galten Tierseren mit gemessenen optischen Dichten bzw. Extinktionswerten von über 0,167 als positiv, solche mit Werten darunter oder gleich als negativ.

Bei der Analyse der Rinderseren schnitt der k-ELISA in Punkto Sensitivität mit 85\% am besten ab, da er alle bis auf zwei IFT-positive Proben korrekt detektierte. Sowohl N- als auch i-ELISA schnitten mit 54\% bzw. 15\% schlechter ab. Mit 100\% erreicht der N-ELISA die höchste Spezifität (Abbildung 16), gefolgt von k-ELISA (91\%) und i-ELISA (83\%).

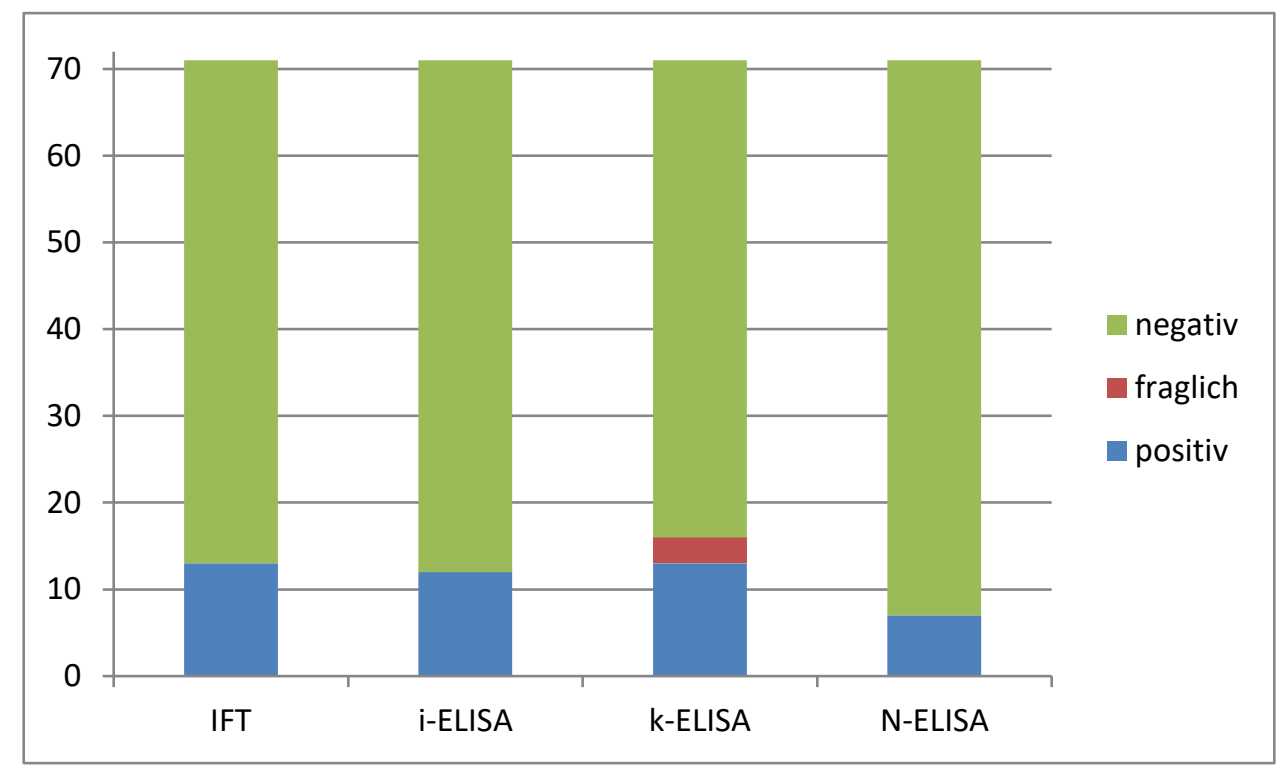

Abbildung 15: Aggregierte Messergebnisse der verwendeten Testverfahren an einer Gruppe von 71 Rinderseren. Immunfluoreszenztest (IFT), indirekter ELISA (i-ELISA), kommerzieller, kompetitiver ELISA ID Screen RVF (IDvet, hier: k-ELISA) und der Gegenstand dieser Arbeit (NELISA). 
Um die Auswirkungen einer erfolgten Impfung auf die Testergebnisse zu untersuchen, wurden weitere Gruppen von je 20 Seren geimpfter Rinder und Schafe getestet, die freundlicherweise von Prof. M. A. H. Shalaby, Universität Kairo, zur Verfügung gestellt wurden. Auf der Gruppe der geimpften Rinder versagten beide Tests. Weder mit N- noch mit k-ELISA konnten Antikörper nachgewiesen werden. Auch eine Steigerung des im NELISA eingesetzten Serumvolumens auf $5 \mu \mathrm{l}$ vermochte nichts an diesem Ergebnis zu ändern.

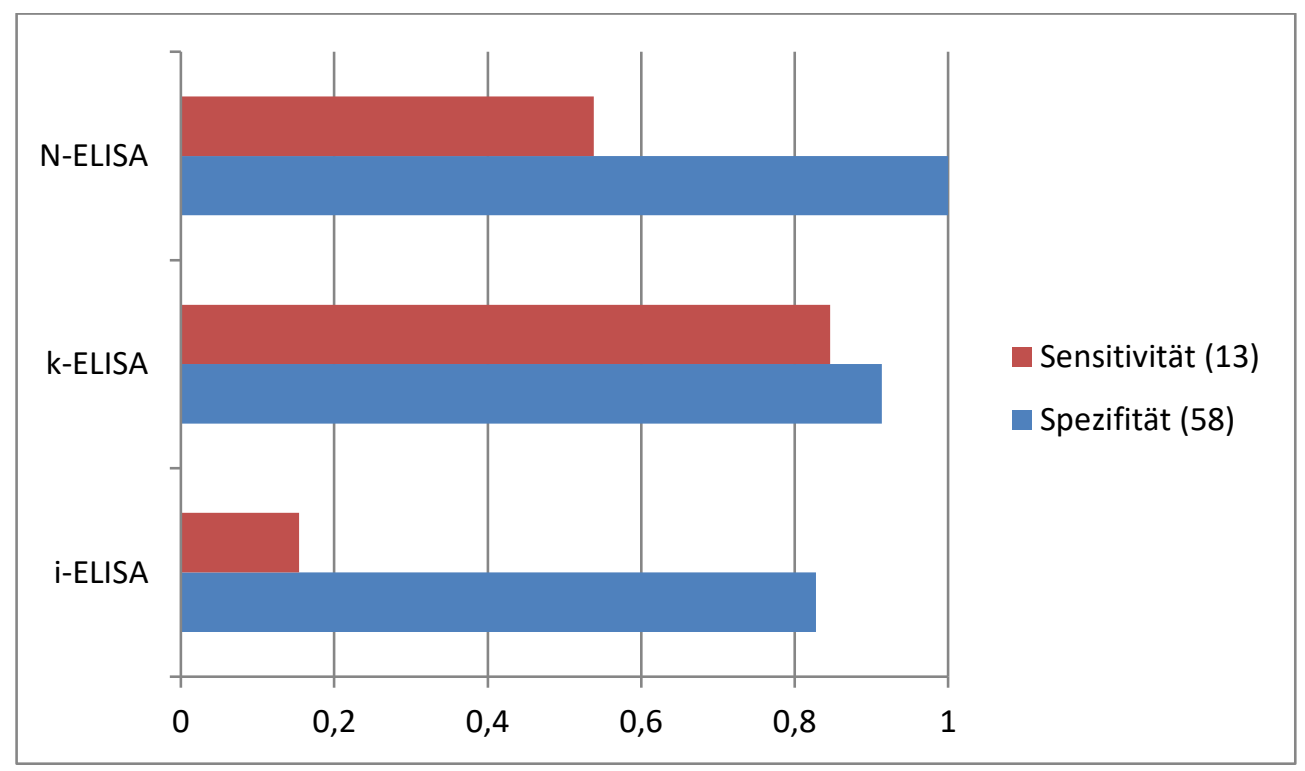

Abbildung 16: Vergleich des N-ELISAs mit dem kompetitiven, kommerziellen Verfahren ID Screen RVF (IDvet, hier: k-ELISA) sowie einem indirekten Sandwich-ELISA (i-ELISA) anhand von Rinderseren. In Klammern angegeben ist die Anzahl an Seren, die in die Berechnung von Sensitivität bzw. Spezifität der Verfahren eingeflossen sind.

Dagegen wurden auf der Gruppe von Schafseren 25\% Sensitivität im k-ELISA (bei $50 \mu$ l) und 55\% im N-ELISA $(5 \mu \mathrm{l})$ erzielt. Aufgrund der großen Ergebnisschwankungen zwischen Rindern und Schafen stellt sich die Frage nach der Robustheit der Tests. Dazu wurden alle Schafseren einer zusätzlichen Verdünnungsreihe unterzogen und erneut getestet. Es zeigte sich, dass die Sensitivität des k-ELISAs bereits bei einer Verdünnung von 0,1 auf null abfiel, wo sie hingegen beim N-ELISA erst ab einer Verdünnung von 0,05 auf $20 \%$ sank (Abbildung 17). 


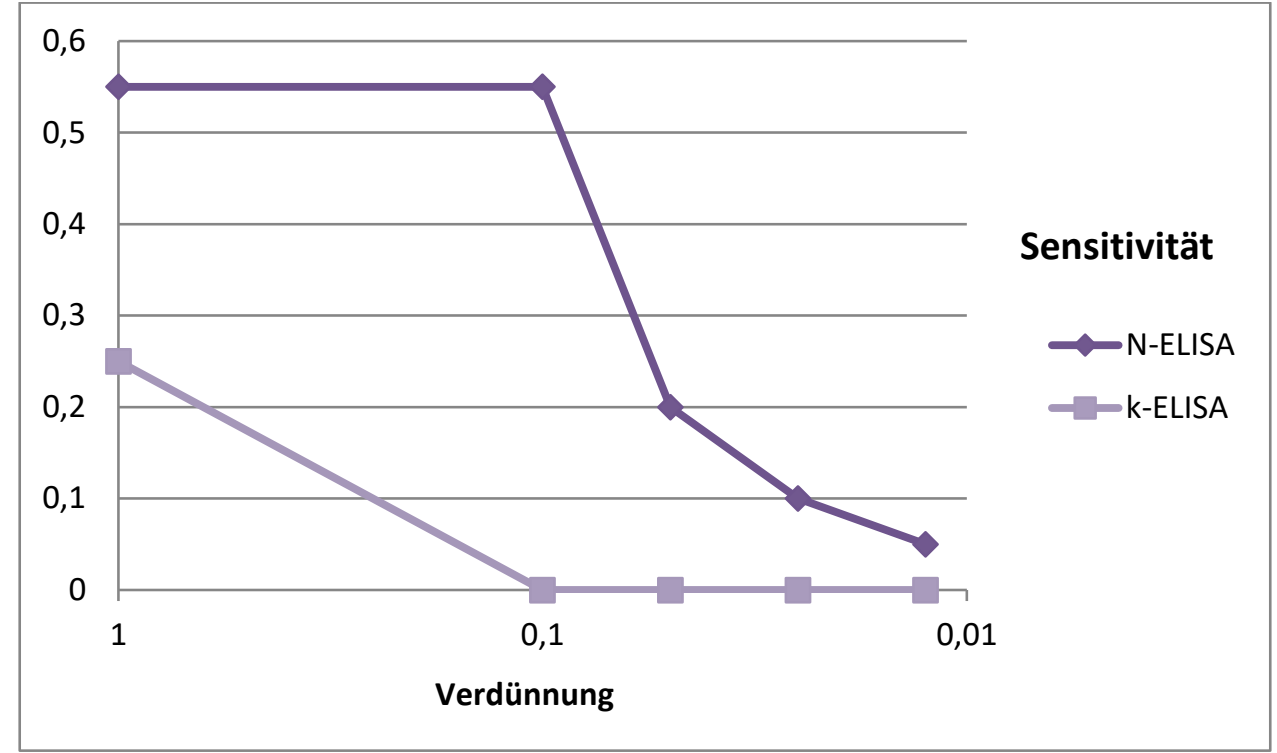

Abbildung 17: Sensitivität des N-ELISAs auf Nukleoprotein-Antikörper in Seren von geimpften Schafen bei zunehmender Verdünnung, im Vergleich zum kommerziellen Verfahren IDvet (k-ELISA).

\subsection{Entwicklung eines ELISAs zur Kontrolle des Impfschutzes}

Zur Kontrolle eines Impferfolges wird ein ELISA benötigt, der spezifisch jene Antikörper detektiert, die langfristigen Schutz vor einer RVFV-Infektion verleihen (4.2). Dies sind in der Regel diejenigen Antikörper, die gegen das Gn/Gc-Protein auf der Virushülle gerichtet sind, da sie die Gn/Gc-vermittelte Bindung und das Eindringen des Virus in die Zelle und somit eine Infektion verhindern. Zu diesem Zweck wurde das RVFV-Gn-Protein kloniert und exprimiert, um es als Coating der Mikrotiterplatte eines RVFV-Gn-ELISAs einsetzen zu können.

Als Klonierungsstrategie wurde zunächst eine TA-Klonierung der RVFV-Gn-DNA in das pCRIIPlasmid gewählt, gefolgt von einer Umklonierung in das pQE9-Plasmid mittels Restriktionsenzymen. Dies erlaubt es, das RVFV-Gn-Protein induzierbar zu exprimieren und erleichtert die spätere Aufreinigung mittels Affinitätschromatographie (2.2.2) über das in der pQE9-Expressionskassette enthaltene His-Tag (Abbildung 9). 


\subsubsection{Herstellung des Plasmids pCRII-RVFV-Gn über TA-Klonierung}

\subsubsection{Amplifikation der cDNA des RVFV-Gn-Oberflächenproteingens}

Für die Expression des RVFV-Gn-Oberflächenproteins wurde zuerst RNA aus einer Kultur RVFV infizierter Säugerzellen isoliert (2.5.1), in DNA umgeschrieben (2.5.3), diese dann mit Hilfe von RVFV-Gn spezifischen Primern (RVFV-GnS-for und RVFV-GnS-rev) amplifiziert (2.5.4) und über ein präparatives Agarosegel isoliert (2.5.5). Die amplifizierten DNAFragmente hatten eine Größe von ca. 1300 Basenpaaren.

\subsubsection{TA-Klonierung des pCRII-RVFV-Gn Plasmids}

Die RVFV-Gn-DNA wurde mittels TA-Klonierung (2.5.6) in das pCRII-Plasmid eingebracht. Aufgrund der beschränkten Effizienz dieses Schrittes war es erforderlich, E. coli-Kulturen mit RVFV-cDNA von solchen zu trennen, die das unveränderte pCRII-Plasmid exprimieren. Dies erfolgte mit Hilfe der sogenannten Blau-Weiß-Selektion (2.5.6). Die entsprechenden Kulturen wurden auf diese Weise anhand der nicht vorhandenen Blaufärbung selektiert und in Flüssigkulturen vermehrt, woraus schließlich eine große Menge Plasmid-DNA isoliert werden konnte (2.5.7).

\subsubsection{Kontrollverdau und Sequenzierung des hergestellten rekombinanten pCRII- RVFV-Gn Plasmids}

Die Kontrolle des hergestellten rekombinanten Plasmids erfolgte per Verdau (2.5.8). Dazu wurden zehn Plasmidproben auf ein 1\%iges Agarosegel aufgetragen und durch Gelelektrophorese (2.5.5) aufgetrennt. Alle Probenspuren zeigen Banden der erwarteten Größen (Abbildung 18). Eine abschließende Sequenzierung (2.5.9) ergab das Vorliegen des fehlerfreien Inserts in der gewünschten Orientierung. 


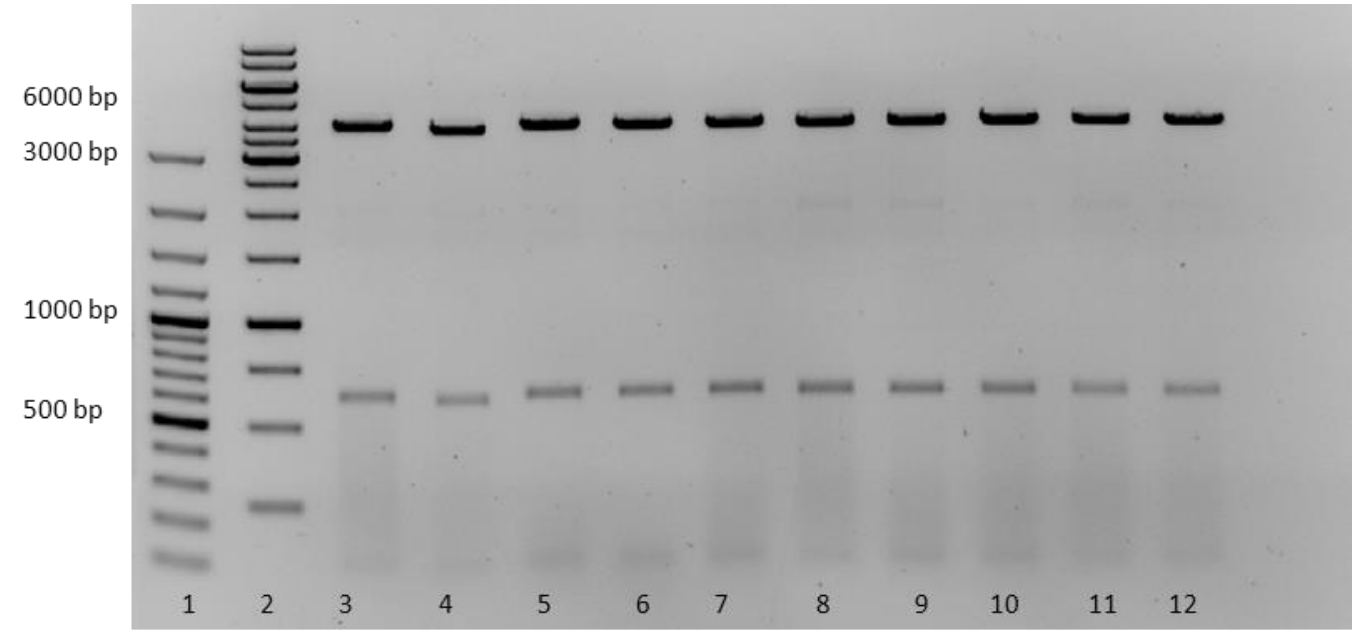

Abbildung 18: Agarosegel des Kontrollverdaus des hergestellten rekombinanten Plasmids. Spur 1: DNA-Längenstandard (100 bp), Spur 2: DNA-Längenstandard (1 kbp), Spur 3-12: Vektorbanden bei etwa $4 \mathrm{kbp}$ und $100 \mathrm{bp}$, Insertbande bei $600 \mathrm{bp}$.

\subsubsection{Subklonierung von RVFV-Gn-cDNA in PQE9}

Zunächst wurde der Expressionsvektor pQE9 (Abbildung 19) in einem Doppelverdau mit BamHI und Sall innerhalb des Klonierungsbereichs geschnitten und linearisiert. Um eine Autoligation auszuschließen, wurde der Vektor mit alkalischer Phosphatase behandelt.

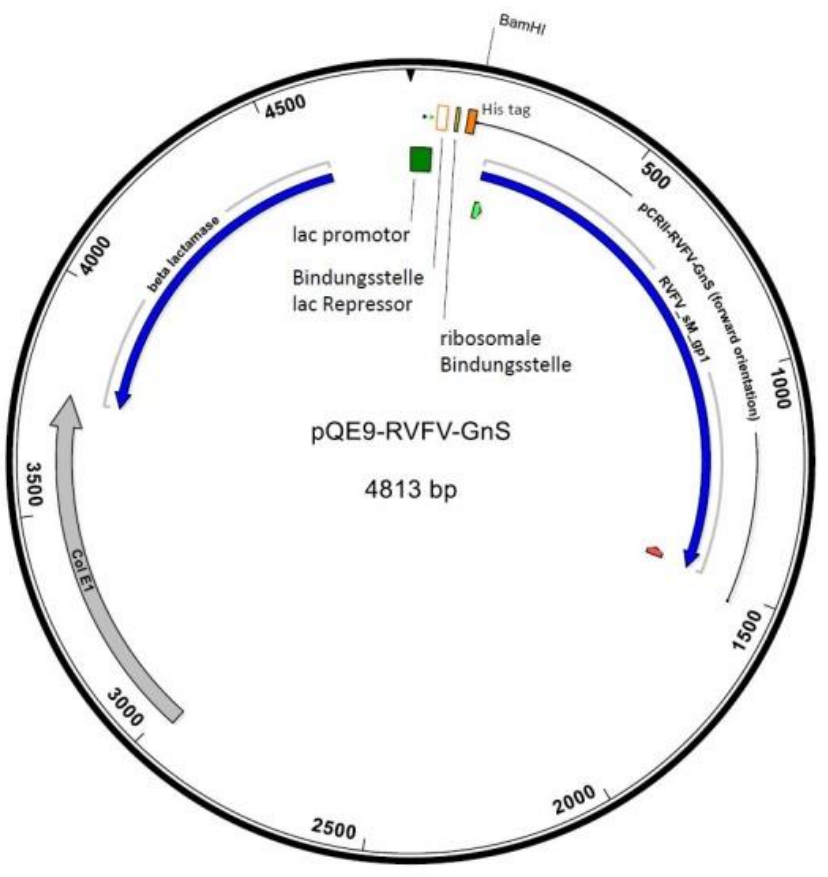

Abbildung 19: Das konstruierte Plasmid pQE9-RVFV-Gn. 


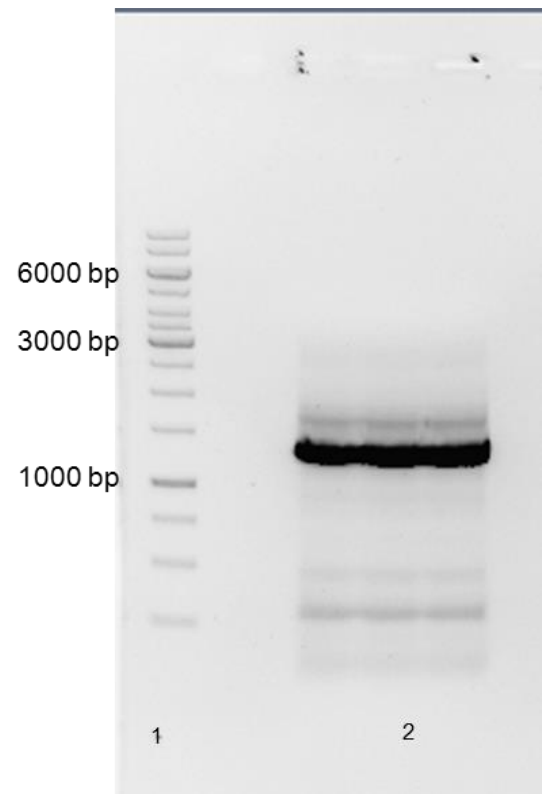

Abbildung 20: Elektrophoretische Auftrennung der RVFV-Gn-cDNA-Fragmente im Agarosegel. Spur 1: DNA-Längenstandard (1 kbp), Spur 2: RVFV-Gn (1300 bp).

Aus dem zuvor klonierten Vektor pCRII-RVFV-Gn wurde mit Hilfe eines BamHI/XholDoppelverdaus die RVFV-Gn-cDNA ausgeschnitten und anschließend mit Hilfe eines präparativen Agarosegels isoliert (Abbildung 20). Für die anschließende Ligation wurden die Gn-cDNA im 1:4-Verhältnis zum Vektor eingesetzt. Nach erfolgter Reaktion wurden die Ligationsansätze in kompetente E. coli XL1 Blue transformiert (2.5.6.2). Analog zum Vorgehen in (3.3.1) wurden die Klonkolonien der Farbe nach differenziert, vermehrt und das rekombinante Plasmid isoliert. Die erreichte Konzentration des Plasmids wurde spektrophotometrisch (2.5.2) gemessen, eine Sequenzanalyse (2.5.9) ergab das Vorliegen des fehlerfreien Inserts in der gewünschten Orientierung.

\subsubsection{Expression des RVFV-Gn-Proteins}

Nach der erfolgreichen Herstellung des Expressionsplasmids für RVFV-Gn wurde das rekombinante Protein in E. coli exprimiert (2.2.1). Verschiedenen Proteinproben wurden auf ein SDS-Gel aufgetragen und mittels SDS-PAGE aufgetrennt (2.2.3). Als nächstes wurden diese Proben auf eine PVDF-Membran transferiert und anschließend im Western Blot mittels Chemilumineszenz-Reaktion (ECL) nachgewiesen (2.2.4). 
Es wurden sechs Proteinfraktionen auf das SDS-Gel aufgetragen anschließend aufgetrennt. Die Proteinkonzentration nimmt von Fraktion eins bis sechs ab. Die aufgereinigten Proteine wurden mittels zweier Immunoblots nachgewiesen, bei denen primäre Anti-RVFVAntikörper aus Ziege mit sekundären, Peroxidase-markierten (HRP) Anti-Ziege-Antikörpern kombiniert (Abbildung 21) oder HRP-anti-His-tag Antikörper (Abbildung 22) zur Detektion verwendet wurden. Zur Dialyse für die weitere Verwendung des Proteins wurden die vier Fraktionen mit der höchsten Proteinkonzentration vereinigt.

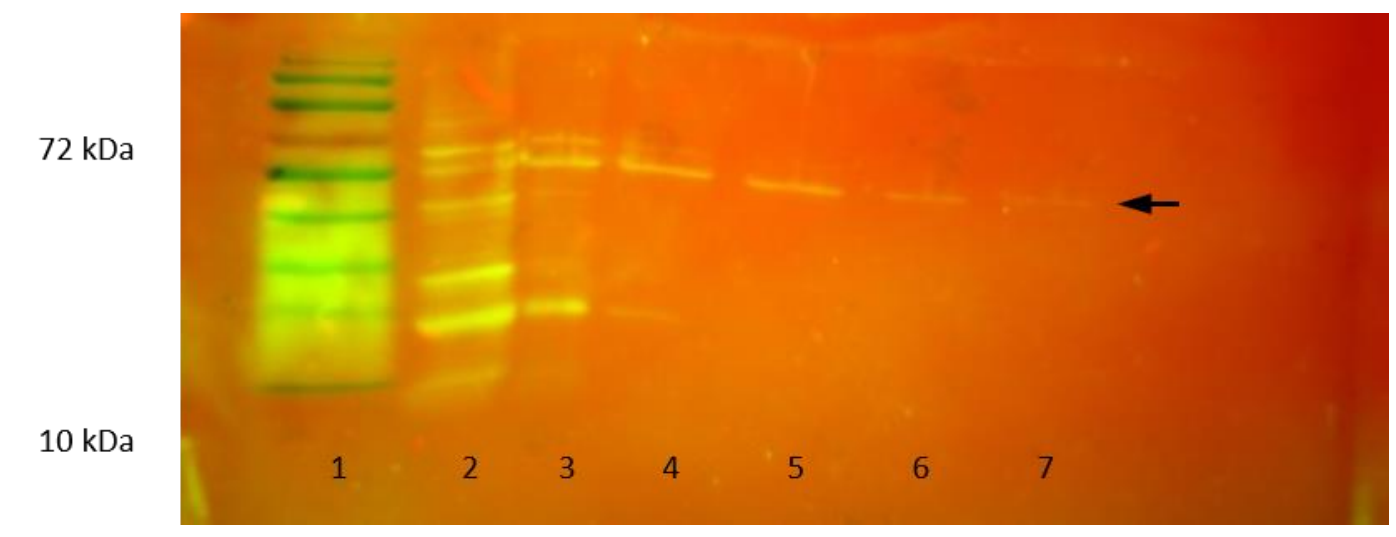

Abbildung 21: Nachweis des exprimierten RVFV-Gn-Proteins mittels Anti-RVFV-Antikörpern und Western Blot. Spur 1: Molekulargewichtsmarker (10-170 kDa), Spuren 2-7, Pfeil: RVFV-GnProteinfraktionen $(55 \mathrm{kDa})$ in abnehmender Proteinkonzentration.

\subsubsection{Erprobung des Gn-ELISAs}

Ein auf Basis des exprimierten RVFV-Gn-Proteins erstellter, speziesspezifischer RVFV-GnELISA wurde anhand von 20 Seren geimpfter Schafe, 15 Seren geimpfter Rinder sowie 48 Humanseren erprobt, wobei entsprechende enzymmarkierte Sekundärantikörper zum Einsatz kamen (1.3.1). Sensitivität und Spezifität lagen dabei unter 30\%. Als Referenz wurden die zuvor durchgeführten IFT Ergebnisse herangezogen. Als Ursache dieses schlechten Ergebnisses kommt eine unzureichende Reinheit des Gn-Proteins in Frage, die sich in überzähligen Banden im Western Blot manifestiert (Abbildung 22). Unspezifische Bindungen konnten bei einer Wiederholung des Versuchs unter Einsatz eines stärkeren Blockreagenz (Roti-Block anstelle von Magermilch/BSA) weitgehend ausgeschlossen werden, wobei jedoch keine Verbesserung der Ergebnisse eintrat. Ebenso wenig führte der 
Ersatz der polyklonalen Anti-Human-Antikörper durch Human-IgG-spezifische Antikörper mit minimaler Kreuzreaktivität gegen tierische Serumproteine zum Ziel.

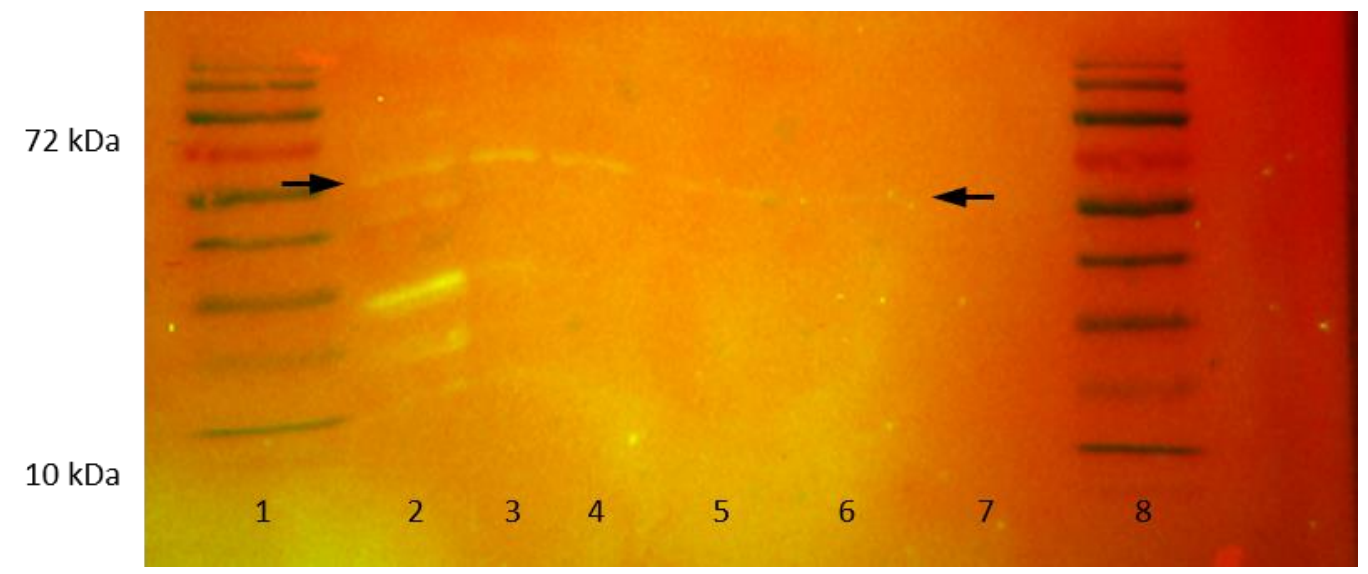

Abbildung 22: Nachweis des exprimierten RVFV-Gn-Proteins mittels Anti-His-tag-Antikörpern und Western Blot. Spur 1 und 8: Molekulargewichtsmarker (10-170 kDa), Spuren 2-7, Pfeile: RVFV-GnProteinfraktionen (55 kDa) in abnehmender Proteinkonzentration. 


\section{Diskussion}

\subsection{Erfolgreiche Etablierung eines speziesunabhängigen RVFV-N- ELISAs}

Das RVF-Phlebovirus gehört zur Familie der Phenuiviren. Es ist ein in Afrika weit verbreitetes Virus, welches sowohl Menschen als auch Säugetiere befällt und seit einigen Jahren auch auf der arabischen Halbinsel nachweisbar ist. Überträger sind dabei Mücken der Gattung Aedes und Culex. Zeitlich und örtlich wiederkehrende Infektionen beim Menschen, insbesondere bei Landwirten und Bauern, lassen sich oft mit einem infizierten Nutztierbestand in Verbindung bringen (vornehmlich Schafe und Rinder). Im Zuge der Infektion treten vor allem Gastroenteritiden auf, aber auch Meningitis, Enzephalitis, Rhetinitis und Hepatitis, die zu hoher Letalität führen (allein 600 Todesfälle in Ägypten 1978). Als potentiell tödlich verlaufende Infektionskrankheit ist RVF daher auch als biologische Waffe in Europa denkbar.

Bei klinischen Verdachtsfällen auf RVF wird in Ländern, in denen das RVF endemisch ist, der serologische Antikörpernachweis verwendet. Dieser Antikörpertest ist bei RVF bereits eine Woche post infectionem möglich (Abbildung 4). Im Gegensatz zu Erregerkultivierung ist die Serodiagnostik eine schnelle und ungefährliche Methode (1.3), die per Titerbestimmung zudem sowohl Aufschluss über den Verlauf der Infektion als auch die Abwehrlage des Patienten liefert.

Zum Nachweis einer RVF-Infektion stehen als Routinediagnostika bislang mehrere ELISA Systeme zu Verfügung, die, wie in Abschnitt 1.3.1 beschrieben, Antikörper gegen den RVFV detektieren. Kommerziell verfügbar ist ein speziesunabhängiger, kompetitiver ELISA (ID Screen RVF, IDvet, hier: k-ELISA), dessen Zulassung aber auf Nutztierseren beschränkt ist und somit nicht zum Test von Humanseren herangezogen werden darf. Die Fähigkeit, mit denselben Reagenzien Seren von Menschen und Tieren zu testen, wäre aber in Ländern mit wenig entwickelten Gesundheitssystemen (wie z. B. Ägypten und dem Sudan) von besonderem Wert. Sowohl IFT als auch k-ELISA benötigen zudem große Probenvolumina. 
Dies ist insbesondere in tropischen Ländern von Nachteil, da dort die notwendigen Kühlkapazitäten während der Probengewinnung und -lagerung oftmals knapp sind. $50 \mu \mathrm{l}$ Serum für einen einzelnen Test wie im Falle des k-ELISAs sind dann wenig praktikabel. Aus den genannten Gründen ist es geboten, ein Verfahren zu entwickeln, das speziesunabhängig ist und bereits mit geringen Probenvolumina einen sicheren Nachweis erbringen kann.

Zur Entwicklung des in dieser Arbeit beschriebenen, speziesunabhängigen ELISAs, wurden die RVFV-Proteine N und Gn als Erfolg versprechende Antigene identifiziert. Im Gegensatz zum Gn-Protein ist das N-Protein kein Hüllenprotein, d. h. es befindet sich im Inneren des Viruspartikels. Aufgrund seiner hohen Abundanz im Viruspartikel wird davon ausgegangen, dass nach der Infektion mit RVFV insbesondere Antikörper gegen das N-Protein gebildet werden (Knipe und Howley 2007). Das Gn-Protein ist ein für den Eintritt des Virions in die Wirtszelle zentraler Bestandteil des äußeren Virus-Kapsids. Durch seine exponierte Lage ist es für die Zellen des Immunsystems unmittelbar zugänglich. Antikörper, die gegen das GnProtein gerichtet sind, schützen vor Reinfektionen mit RVFV, stellen also neutralisierende Antikörper dar. Beide Virusproteine wurden als Basis für die folgenden Experimente biotechnisch hergestellt.

Um hohe Sensitivität und Spezifität mit Speziesunabhängigkeit zu kombinieren, wurde ein ELISA auf Basis des RVFV-N Proteins entwickelt ( $\mathrm{N}$-ELISA), wobei einem Konjugat aus $\mathrm{N}$ Protein und dem Enzym HRP eine Schlüsselfunktion zukommt. Durch die Verwendung dieses Konjugats entfällt die Abhängigkeit von einem speziesspezifischen Antikörper für die Detektion der Primärantikörper im Serum und damit auch ein Inkubationsschritt. Gleichzeitig sollte sich die Spezifität und Sensitivität erhöhen, da das HRP-konjugierte Iösliche Antigen nicht an den Fc-Teil, sondern an eine antigenspezifische Bindungsstelle des zu detektierenden Antikörpers bindet.

Da für RVFV-ELISAs kein kommerzieller Positivstandard erhältlich ist, wurde ein Cut-off-Wert nach Frey berechnet (2.3.1), um eine Aussage über positive Seren treffen zu können. Alle Werte, die oberhalb des berechneten Grenzwertes liegen, gelten als positiver Nachweis von 
Antikörpern im Serum. Mit dem so berechneten Grenzwert war es schließlich möglich, die unterschiedlichen ELISAs (s-, k- und N-ELISA) untereinander bezüglich ihrer Sensitivität und Spezifität zu vergleichen und den neu entwickelten Test auf diese Weise zu etablieren.

In Bezug auf Humanseren übertrifft der hier entwickelte N-ELISA das Vergleichsverfahren (s-ELISA) und nähert sich bezüglich seiner Leistung (Spezifität 99\%, Sensitivität 87\%, Abbildung 14) einem IFT, gegenüber dem der Verbrauch an Serum deutlich reduziert ist.

Die vergleichsweise geringe Sensitivität des N-ELISAs in Bezug auf Nutztiere (54\%, Abbildung 16) liegt noch in einem für ELISA typischen Bereich und wird durch die Tatsache relativiert, dass für seine Durchführung bereits 2\% der Menge an Serum ( $1 \mu \mathrm{l})$ ausreichend sind, die für den kommerziellen ELISA aufgewendet werden muss (50 $\mu$ l, Sensitivität 85\%).

\subsection{Spezielle Aspekte der Verwendung eines ELISAs bei geimpften Tieren}

Durch die konsistent verringerte Sensitivität aller verwendeten ELISAs bei geimpften Tieren stellt sich die Frage nach einem systematischen Effekt. Dazu ist festzustellen, dass N- und kELISA gegen das N-Protein gerichtete Antikörper detektieren. Nun handelt es sich bei den verwendeten Impfstoffen aber um Totimpfstoffe, die in vielen Fällen nur aus Teilen des Pathogens bestehen. Dies legt die Vermutung nahe, dass der RVF-Impfstoff überwiegend aus Antigenen der Virushülle besteht und so N-Antikörper nur in geringen Titern (bei Schafen mehr als bei Rindern) induziert werden. Darüber hinaus kommt der eigentliche Impfschutz nicht durch $\mathrm{N}$-spezifische Antikörper zustande, sondern durch solche, die gegen von außen zugängliche Proteine des Virus, wie das Gn-Protein, gerichtet sind. Nur diese sind in der Lage, intakte Viren zu neutralisieren und so die Infektion weiterer Wirtszellen zu verhindern. Durch die oftmals schwächere Immunantwort auf einen Totimpfstoff kann es notwendig werden, eine Impfung mehrfach zu wiederholen, um den Impfschutz zu garantieren. Zur Prüfung des potentiellen Impfschutzes scheint es daher sinnvoll, einen auf dem Gn-Protein basierenden ELISA zu entwickeln. 
Zur Beurteilung des Impfschutzes von Nutztieren über die Bestimmung des Impftiters wurde der Versuch zur Etablierung eines speziesunabhängigen Anti-RVFV-Gn-ELISAs (GnELISA) gestartet. Dieser Test funktionierte nicht (3.3.4), was nach Abschluss dieser Arbeit auf die mangelnde Zugänglichkeit der antigenen Epitope des exprimierten rekombinanten Gn-Proteins zurückgeführt werden konnte. Mittlerweile ist es gelungen, die 3D-Struktur des Proteins durch Denaturierung mit Guanidium-Hydrochlorid abzuändern, so dass die antigenbindenden Strukturen (Epitope) für Antikörper zugänglich wurden. Mit dem in dieser Weise modifizierten Gn-ELISA konnten in ersten Messungen Gn-Antikörper in Seren von RVFV infizierten Kamelen aus dem Sudan nachgewiesen werden ${ }^{1}$.

Ein weiterer praktischer Aspekt ist die sichere Unterscheidung von Infektion und erfolgter Impfung mittels eines Totimpfstoffes. Diese kann, unter der Annahme eines bestehenden Gn-Antikörpertiters, durch Nachweis von infektionsspezifischen Antikörpern erfolgen. Die Ergebnisse des N-ELISA zeigen, dass Anti-N-Antikörper dieses Kriterium zwar tendenziell erfüllen, ihr Titer aber zu großen Schwankungen unterliegt. Eine bessere Wahl wären daher Antikörper, die gegen das RVFV-NSs-Protein gerichtet sind. Das NSs-Protein ist nicht Bestandteil der Virionen, entsteht aber bei der Virusreplikation. Es sammelt sich im Nucleus an und hemmt durch seine Wirkung als Transkriptionsinhibitor die Interferonproduktion im RVFV-infizierten Organismus. Dadurch wird die antivirale, immunstimulierende Wirkung des Typ-I-Interferons unterdrückt. Daher sollten nur Seren infizierter Tiere im NSs-ELISA positive Resultate ergeben, während es bei mit inaktivierten Viruspartikeln geimpften Tieren, gleich ob Lebend- oder Totimpfstoff, nicht zur Bildung von NSs-Antikörpern kommen kann. Somit würde ein NSs-ELISA eine sichere Unterscheidung von infizierten und geimpften Tieren erlauben.

\footnotetext{
${ }^{1}$ persönliche Mitteilung von Dr. M. Spiegel (2014)
} 


\section{Zusammenfassung}

Das RVF-Phlebovirus gehört zur Familie der Phenuiviren und wird durch Insektenstiche auf Wild- und Nutztiere sowie den Menschen übertragen, zudem ist eine Übertragung von Nutztieren auf den Menschen möglich (Zoonose). Bei Menschen zählen Hepatitiden, hämorrhagisches Fieber und Enzephalitiden zu den möglichen schweren Symptomen der Erkrankung. Bei Nutztieren, insbesondere Rindern, verursacht die Infektion bei trächtigen Tieren Teratogenität, Abort und den Tod des Jungtiers. Die Erkrankung ist in vielen Gebieten der Subsahara, in Ägypten und der arabischen Halbinsel endemisch, wo es wiederholt zum Ausbruch von Epidemien gekommen ist.

Der RVFV-N-Antikörper-ELISA ist ein Screeningverfahren, das auch in schlecht ausgestatteten Laboren routinemäßig eingesetzt werden kann. Der nach Sensitivität und Spezifität bisher beste kommerziell verfügbare ELISA ist jedoch nicht speziesübergreifend anwendbar. Im Rahmen dieser Arbeit wurde daher ein neues ELISA-Verfahren entwickelt, das Speziesunabhängigkeit mit guter Sensitivität und Spezifität vereint. Als ein geeignetes Zielprotein wurde dazu das RVFV-Nukleoprotein identifiziert und das HRP-konjugierte NProtein zur Detektion von RVFV-N-Antikörpern verwendet. Aus den so gewonnenen Erkenntnissen konnten Richtungsentscheidungen für die Etablierung von weiteren Zielproteinen (RVFV-Gn und -NSs) abgeleitet werden, die dem Ziel einer präzisen Klassifikation von geimpften und ungeimpften Tieren dienen. 


\section{Literaturverzeichnis}

Ahmed Kamal S (2011): Observations on rift valley fever virus and vaccines in Egypt. Virol J $\underline{8}, 532$

Bird BH, Ksiazek TG, Nichol ST, Maclachlan NJ (2009): Rift Valley fever virus. J Am Vet Med Assoc 234, 883-93

Corso B, Pinto J, Beltrain-Alcrudo D, De Simone L, Lubroth J: Rift Valley fever outbreaks in Madagascar and potential risks to neighbouring countries. FAO EMPRES Watch, April 2008, http://www.fao.org/3/a-aj213e.pdf; abgerufen am 28.12.2019

Crowther JR: The ELISA guidebook (Methods in Molecular Biology). Humana Press, Totowa 2000

Daubney R, Hudson JR, Graham PC (1931): Enzootic hepatitis of Rift Valley fever, an undescribed virus disease of sheep, cattle and man from East Africa. J Pathol and Bacteriol 34, 545-579

Flint SJ, Enquist LW, Racaniello VR, Skalka AM: Principles of Virology: Molecular Biology, Pathogenesis, and Control of Animal Viruses. 2. Auflage; ASM Press, Washington, D.C. 2004

Frey A, Di Canzio J, Zurakowski D (1998): A statistically defined endpoint titer determination method for immunoassays. J Immunol Methods 221, 35-41

Hartley DM, Rinderknecht JL, Nipp TL, Clarke NP, Snowder GD (2011): Potential effects of Rift Valley fever in the United States. Emerg Infect Dis 17, e1

Heinrich N, Saathoff E, Weller N, Clowes P, Kroidl I, Ntinginya E, Machibya H, Maboko L, Loscher T, Dobler G, et al. (2012): High seroprevalence of Rift Valley Fever and Evidence for Endemic Circulation in Mbeya region, Tanzania, in a Cross-Sectional Study. PLoS Negl Trop Dis $\underline{6}$, e1557

ILRI (International Livestock Research Institute): Mapping of poverty and likely zoonoses hotspots. Zoonoses Projects 4. ILRI, o. O. 2012, cgspace.cgiar.org/handle/10568/21161; abgerufen am 28.12.2019

Kasari TR, Carr DA, Lynn TV, Weaver JT (2008): Evaluation of pathways for release of Rift Valley fever virus into domestic ruminant livestock, ruminant wildlife, and human populations in the continental United States. J Am Vet Med Assoc 232, 514-29

Key G: Labormethoden. In: Raem AM, Rauch PR (Hrsg.): Immunoassays. Elsevier, München 2007, 51-54

Knipe DM, Howley P: Fields Virology. Lippincott Williams \& Wilkins, Philadelphia 2007

Krauss H, Weber A, Appel M, Enders B, v. Graevenitz A, Isenberg HD, Schiefer HG, Slenczka W, Zahner $\mathrm{H}$ : Zoonosen - Von Tier zu Mensch übertragbare Infektionskrankheiten. 3. Auflage; Deutscher Ärzteverlag, Köln 2004

Lopez N, Muller R, Prehaud C und Bouloy M (1995): The L protein of Rift Valley fever virus can rescue viral ribonucleoproteins and transcribe synthetic genome-like RNA molecules. J Virol $\underline{69}, 3972-9$ 
Madani TA, Al-Mazrou YY, Al-Jeffri MH, Mishkhas AA, Al-Rabeah AM, Turkistani AM, AlSayed MO, Abodahish AA, Khan AS, Ksiazek TG, et al. (2003): Rift Valley fever epidemic in Saudi Arabia: epidemiological, clinical, and laboratory characteristics. Clin Infect Dis $\underline{37}$ 1084-92

Modrow S, Falke D, Truyen U und Schätzl H: Molekulare Virologie. 3. Auflage, Spektrum Akademischer Verlag, Heidelberg 2010

Mondet B, Theoretical cycle of RVF virus transmission. In: FAO Animal Health Manual No. 17, Food and Agriculture Organization of the United Nations, Rom 2003, www.fao.org/3/ Y4611E/y4611e04.htm\#bm4; abgerufen am 30.12.2019

NICD (National Institute for Communicable Diseases): Outbreak of Rift Valley Fever. NICD, Johannesburg 2018, www.nicd.ac.za/outbreak-of-rift-valley-fever; abgerufen am 30.12.2019

Pepin M, Bouloy M, Bird BH, Kemp A, Paweska J (2010): Rift Valley fever virus (Bunyaviridae: Phlebovirus): an update on pathogenesis, molecular epidemiology, vectors, diagnostics and prevention. Vet Res 41, 61; lizenziert unter creativecommons.org/licenses/by-nc/3.0/

Peters CJ, Reynolds JA, Slone TW, Jones DE, Stephen EL (1986): Prophylaxis of Rift Valley fever with antiviral drugs, immune serum, an interferon inducer, and a macrophage activator. Antiviral Res $\underline{6}$, 285-97

Raem AM, Goldmann C, Brandt B: Biologische Grundlagen der Immunoassays. In: Raem AM, Rauch PR (Hrsg.): Immunoassays. Elsevier, München 2007, 2

RKI (Robert Koch Institut): Rift-Valley-Fieber: Ausbruch in den nordöstlichen und den Küsten-provinzen Kenias. RKI, Berlin 2007, edoc.rki.de/bitstream/handle/176904/4344/ 23Jt4FXr1Tx6Q.pdf; abgerufen am 30.12.2019

Sanger F, Nicklen S, Coulson AR (1977): DNA sequencing with chain-terminating inhibitors. Proc Natl Acad Sci U S A $\underline{74}$, 5463-7

Taylor LH, Latham SM, Woolhouse ME (2001): Risk factors for human disease emergence. Philos Trans R Soc Lond B Biol Sci 356, 983-9

Yalow RS, Berson SA (1960): Immunoassay of endogenous plasma insulin in man. J Clin Invest $\underline{39}, 1157$

ViralZone: Phenuiviridae. Swiss Institute of Bioinformatics, Lausanne 2019, viralzone.expasy.org/7101; abgerufen am 30.12.2019, lizenziert unter creativecommons.org/licenses/by-nc-nd/4.0/

Wagner E: Die Contagien und Miasmen. In: Wagner E (Hrsg.): Handbuch der allgemeinen Pathologie. 6. Auflage; Verlag Wigand, Leipzig 1874, 174-192

Warrington R, Watson W, Kim HL, Antonetti FR (2011): An introduction to immunology and immunopathology. Allergy Asthma Clin Immunol 7 Suppl 1, S1

Zoonosen.net: Nationale Forschungsplattform für Zoonosen, Münster 2019, zoonosen.net/ überuns.aspx; abgerufen am 24.04.2012 


\section{Veröffentlichungen}

Teile dieser Doktorarbeit wurden als Kongressbeitrag veröffentlicht:

Schmidt U, Paluschkiwitz A, Abd El Wahed A, Shalaby M, Dobler G, Heinrich N, Hufert FT, Spiegel M (2013): Establishment and evaluation of a simple, non-competitive, multi-species anti-RVFV nucleoprotein ELISA. Posterpräsentation im Rahmen des 23rd Annual Meeting of the Society for Virology, Kiel, 06.03.-09.03.2013 


\section{Danksagung}

An dieser Stelle möchte ich mich ganz herzlich bei all denjenigen bedanken, die mich bei der Erstellung dieser Arbeit unterstützt haben:

Herrn Prof. Dr. med. Frank Hufert danke ich herzlich für die Überlassung des Themas und die Betreuung der Dissertation sowie die Möglichkeit, diese in der Abteilung Virologie am Zentrum Hygiene und Humangenetik der Medizinischen Fakultät der Universität Göttingen durchzuführen.

Ganz besonderer Dank gilt Herrn Dr. rer. nat. Martin Spiegel für die praktische Anleitung und wissenschaftliche Unterstützung sowie für die Korrektur der schriftlichen Arbeit, ebenso wie für die Geduld und stete Diskussionsbereitschaft.

Den Mitarbeitern des Labors, Dr. rer. nat. Meik Dilcher, Andrea Paluschkiwitz und Susanne Böhlken-Fascher, gilt ein herzliches Dankeschön für ihre Hilfsbereitschaft, für die praktische Anleitung und die Unterstützung im Labor. 